\title{
DOT 7A FRP BOX FIRE TEST AT THE INEL
}

ROBERT M. BROWN

June 1979
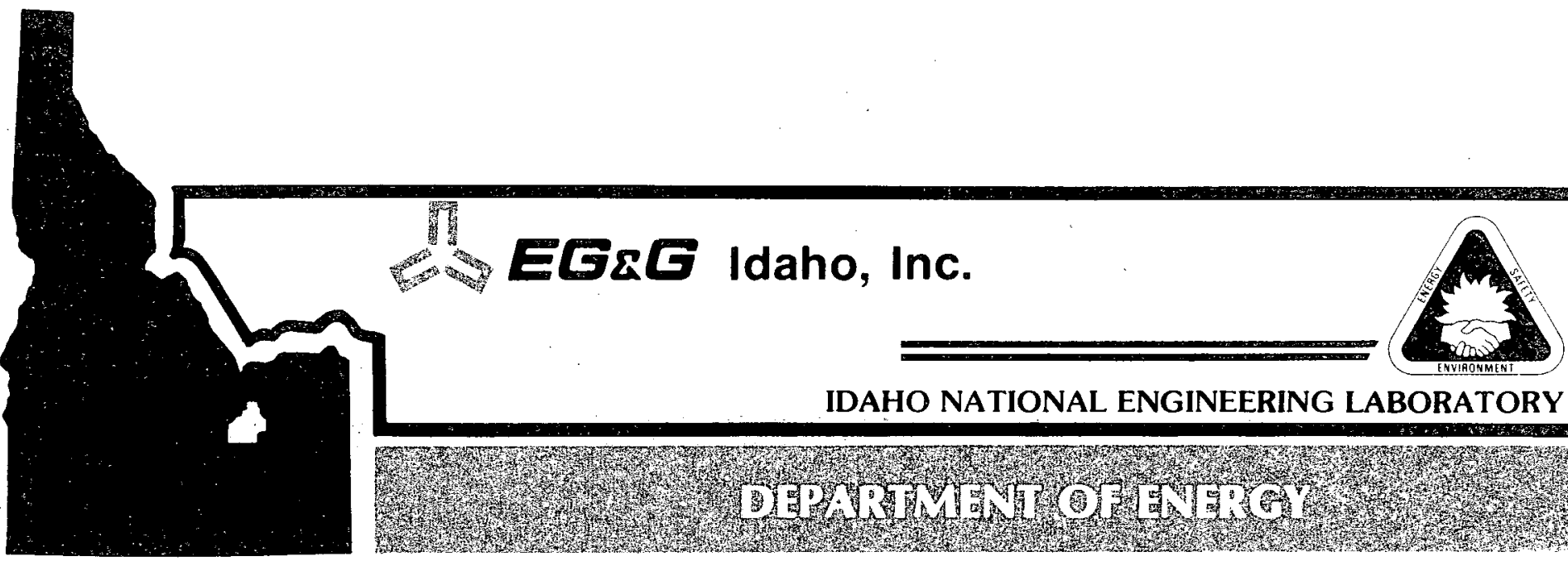

IDAHO NATIONAL ENGINEERING LABORATORY

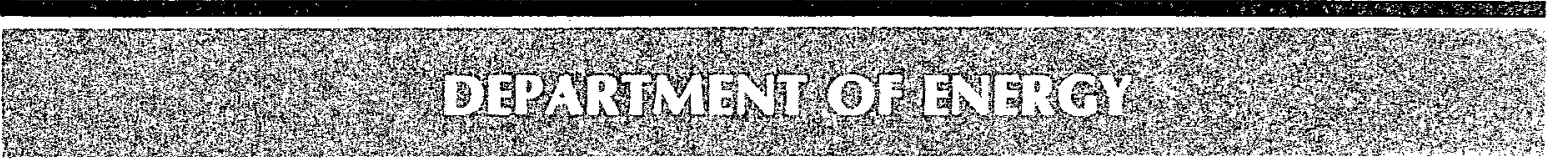

IDAHO OPERATIONS OFFICE UNDER CONTRACT DE-AC07-76ID01570 


\section{DISCLAIMER}

This report was prepared as an account of work sponsored by an agency of the United States Government. Neither the United States Government nor any agency Thereof, nor any of their employees, makes any warranty, express or implied, or assumes any legal liability or responsibility for the accuracy, completeness, or usefulness of any information, apparatus, product, or process disclosed, or represents that its use would not infringe privately owned rights. Reference herein to any specific commercial product, process, or service by trade name, trademark, manufacturer, or otherwise does not necessarily constitute or imply its endorsement, recommendation, or favoring by the United States Government or any agency thereof. The views and opinions of authors expressed herein do not necessarily state or reflect those of the United States Government or any agency thereof. 


\section{DISCLAIMER}

Portions of this document may be illegible in electronic image products. Images are produced from the best available original document. 
TREE-1367

Distribution Category

UC-70

\section{DOT 7A FRP BOX FIRE TEST AT THE INEL}

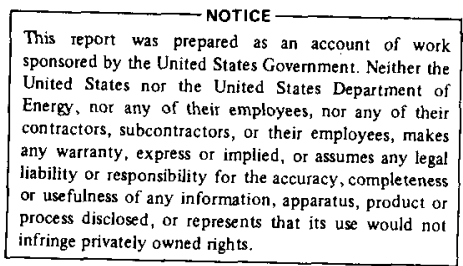

Robert M. Brown

EG\&G Idaho, Inc. Idaho Falls, Idaho 83401

Published June 1979

PREPARED FOR THE

U.S. DEPARTMENT OF ENERGY

IDAHO OPERATIONS OFFICE

UNDER CONTRACT NO. DE-AC07-76ID01570 


\section{ACKNOWLEDGMENTS}

The advice and guidance of John D. Jensen, fire protection engineer, EG\&G Idaho, Inc. and J. Milloy, engineer, Sandia Laboratory, Albuquerque, New Mexico in the preparation of this report is gratefully acknowledged. Appreciation is expressed to R. M. Schletter and the staff of the Waste Management Programs-Operations Project, EG\&G Idaho, Inc., for their assistance and review of the text. 


\begin{abstract}
Two fire tests were conducted at the INEL in December 1978, using both DOT 7A FRP boxes and DOT $17 \mathrm{C}$ steel drums. The containers tested were stacked in a configuration simulating the present storage array used at the RWMC. The fire tests revealed that when the DOT 7A FRP boxes were exposed to a small ignition source they would (a) in the WIPP environment, propogate fire resulting in the penetration of the boxes and probable spread of contamination unless fire suppression measures are taken, and (b) in the RWMC environment, probably not propogate the fire through the stack (the fire self extinguished during this test) although the possibility of the box breaching still exists, unless fire suppression measures are taken. The fire tests also revealed that the DOT $17 \mathrm{C}$ steel drums slowed the fire spread to the boxes, but that the rigid PVC (polyvinyl chloride) liner contained in the drum is highly combustible and presents an additional hazard. Under these test conditions, it was shown that a box could withstand the fire for at least 40 minutes without penetration, which would allow ample fire fighting response time if the blaze is defected early.
\end{abstract}




\section{CONTENTS}

ACKNOWLEDGMENTS $\ldots \ldots \ldots \ldots \ldots \ldots \ldots \ldots \ldots \ldots \ldots \ldots \ldots \ldots \ldots \ldots \ldots \ldots \ldots \ldots \ldots$

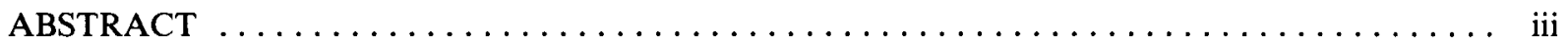

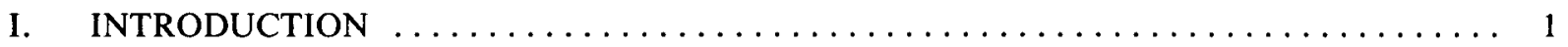

1. IGNITION SOURCE $\ldots \ldots \ldots \ldots \ldots \ldots \ldots \ldots \ldots \ldots \ldots \ldots \ldots \ldots$

2. WASTE CONTAINER CONFIGURATIONS $\ldots \ldots \ldots \ldots \ldots \ldots \ldots \ldots \ldots \ldots$

II. FIRE TEST SETUP AND INSTRUMENTATION $\ldots \ldots \ldots \ldots \ldots \ldots \ldots \ldots \ldots \ldots$

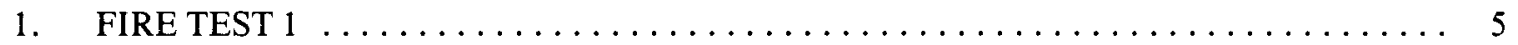

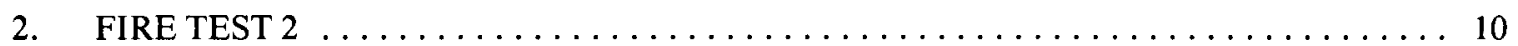

III. FIRE TEST PERFORMANCE $\ldots \ldots \ldots \ldots \ldots \ldots \ldots \ldots \ldots \ldots \ldots \ldots \ldots \ldots \ldots \ldots$

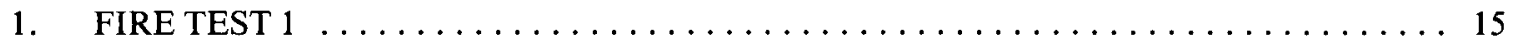

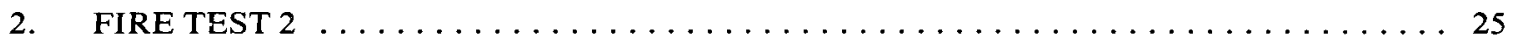

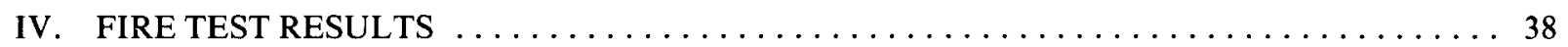

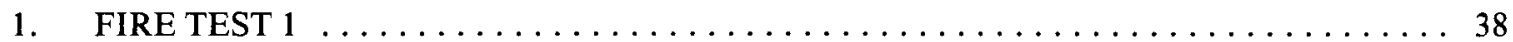

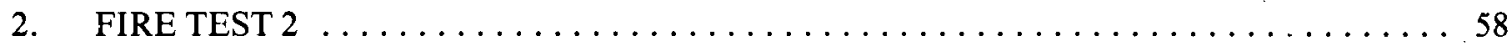

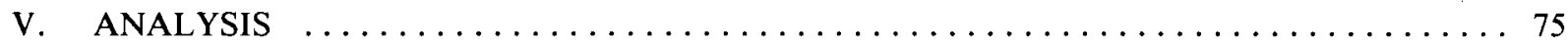

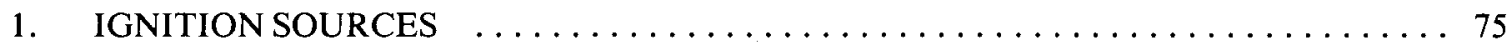

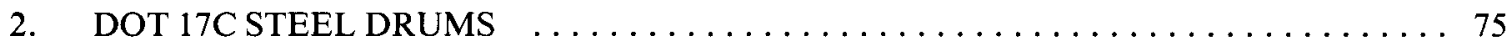

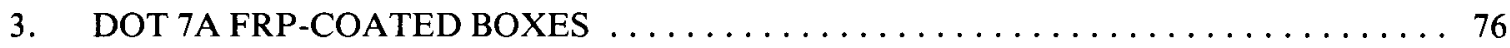

VI. CONCLUSIONS AND RECOMMENDATIONS $\ldots \ldots \ldots \ldots \ldots \ldots \ldots \ldots \ldots \ldots$

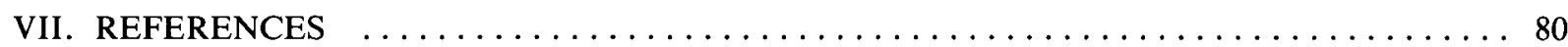

\section{FIGURES}

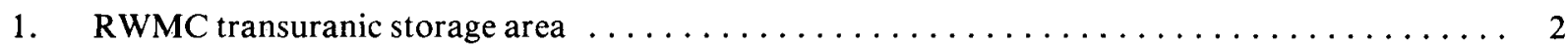

2. RWMC transuranic waste storage configuration $\ldots \ldots \ldots \ldots \ldots \ldots \ldots \ldots \ldots \ldots$

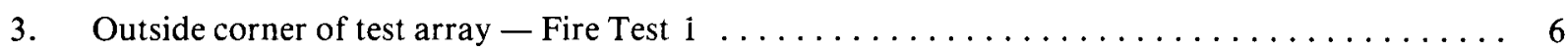

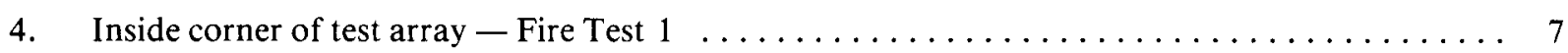

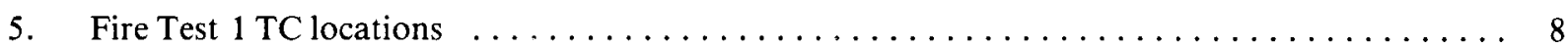


6. Outside corner of test array - Fire Test $2 \ldots \ldots \ldots \ldots \ldots \ldots \ldots \ldots \ldots \ldots \ldots \ldots \ldots \ldots \ldots \ldots \ldots$

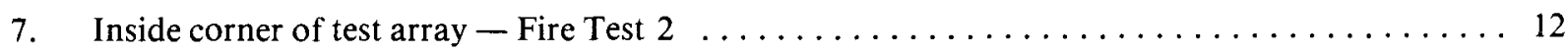

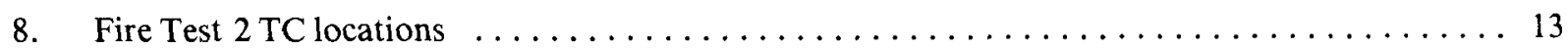

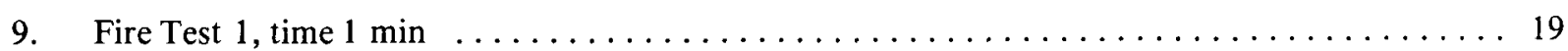

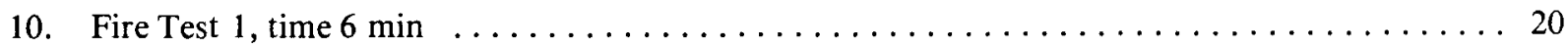

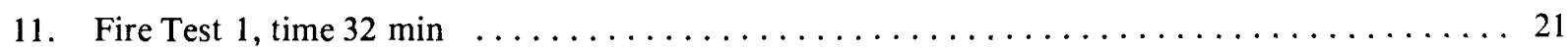

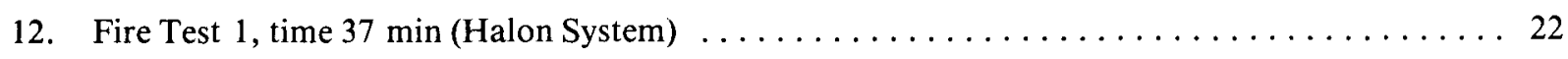

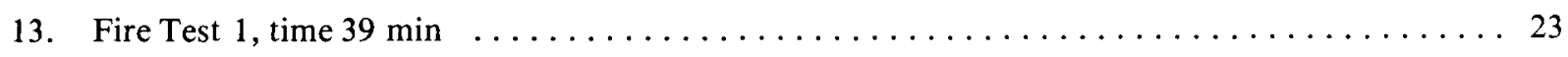

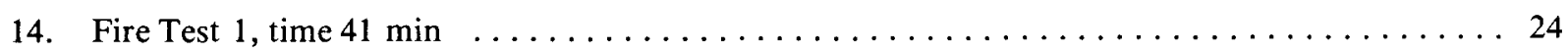

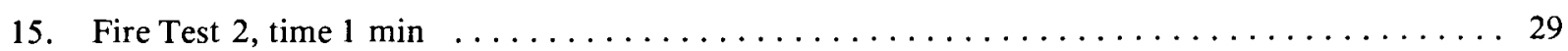

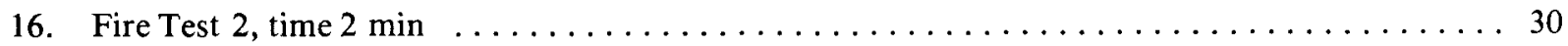

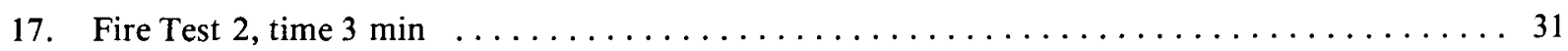

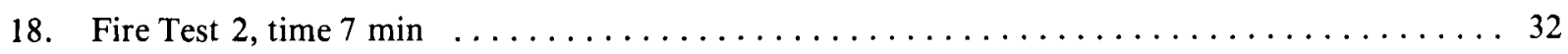

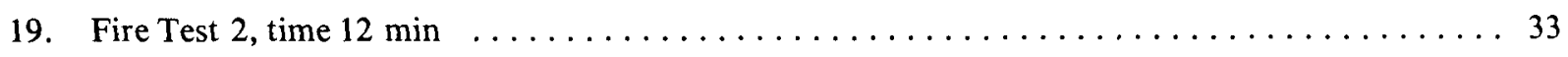

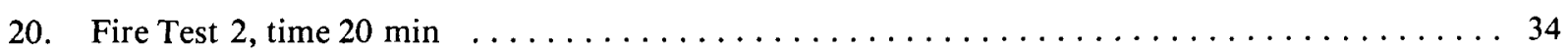

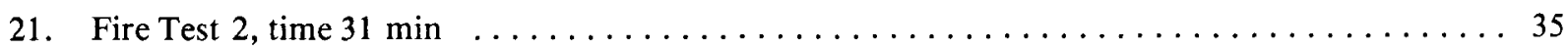

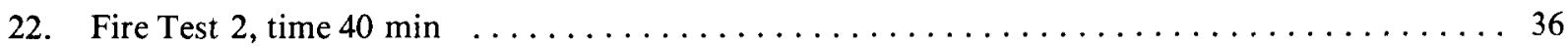

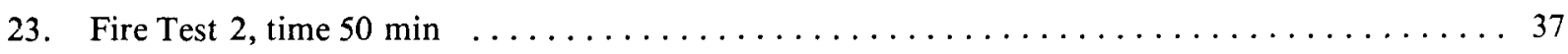

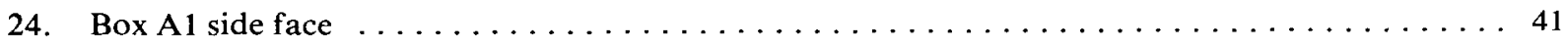

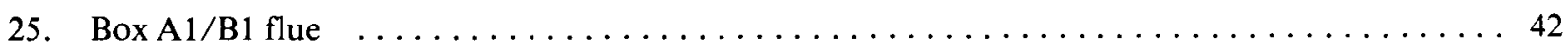

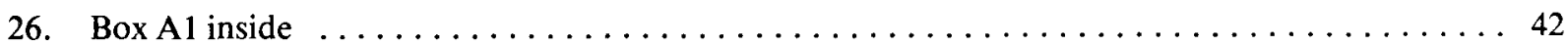

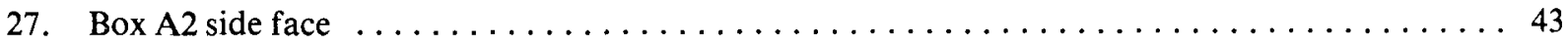

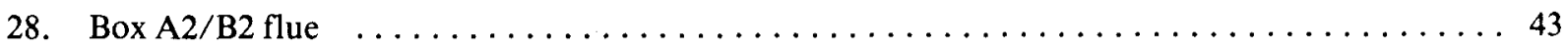

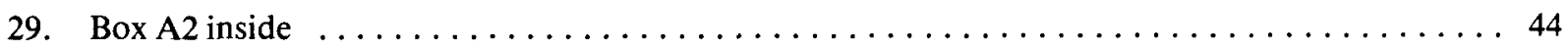

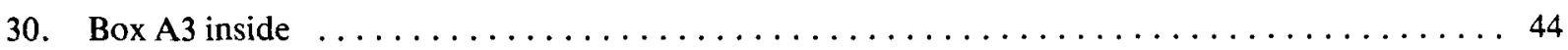

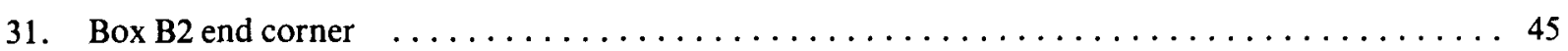

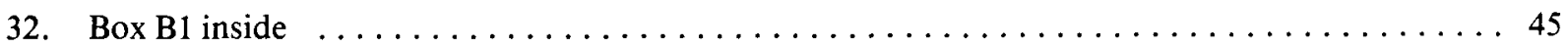

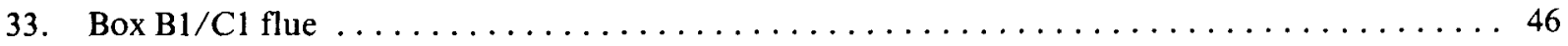




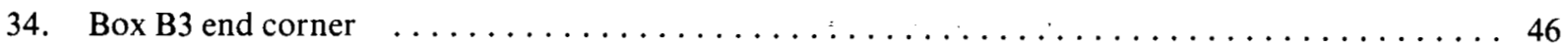

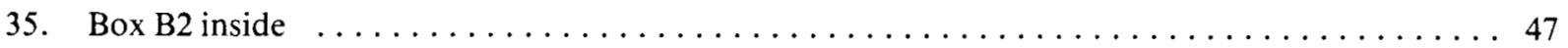

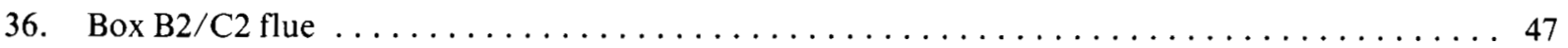

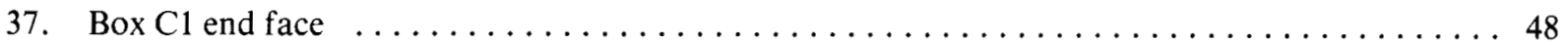

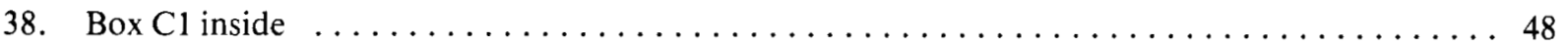

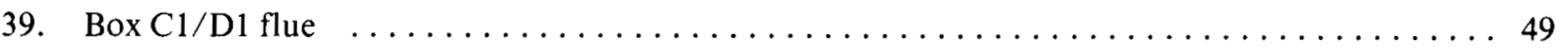

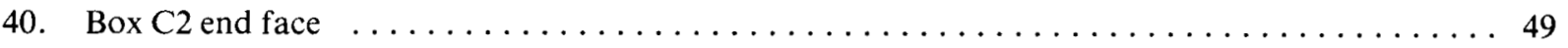

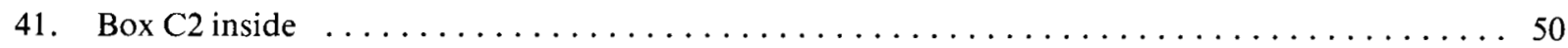

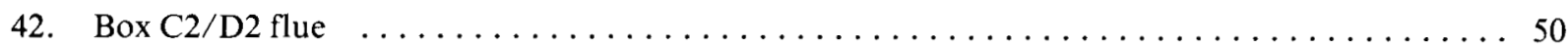

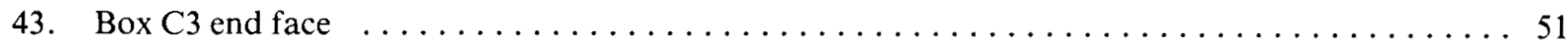

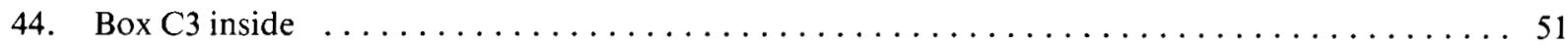

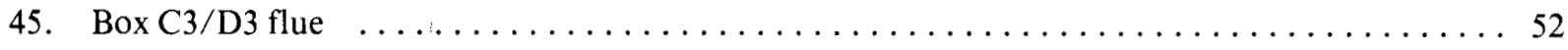

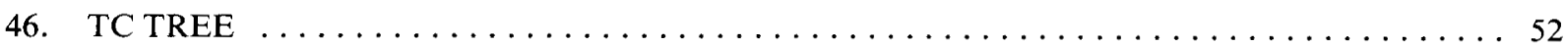

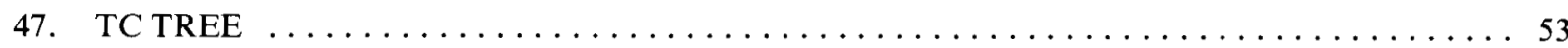

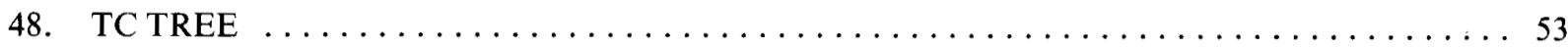

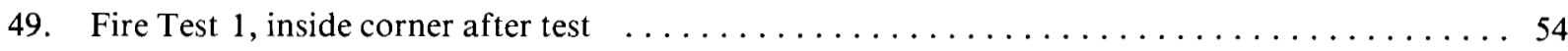

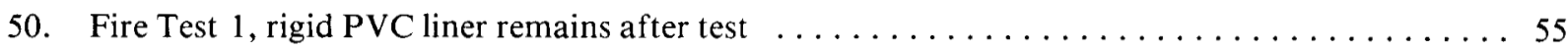

51. Fire Test 1 , inside corner view of boxes in row 1 , stacks 1,2 , and 3 after test $\ldots \ldots \ldots 56$

52. Fire Test 1 , inside corner view of boxes in rows 1 and 2 , stacks 1,2 , and 3 after test $\ldots \ldots 57$

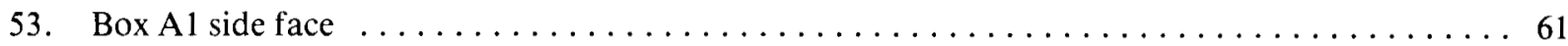

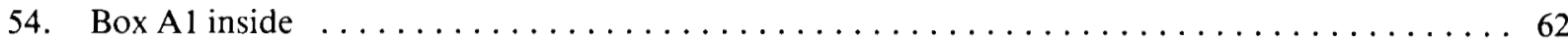

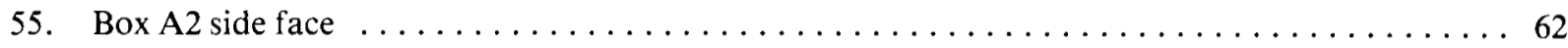

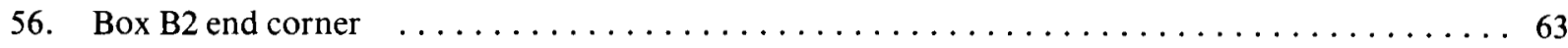

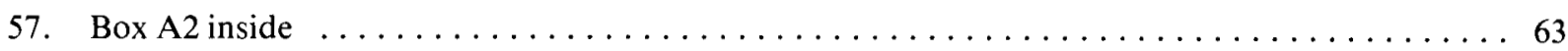

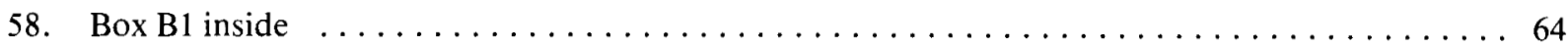

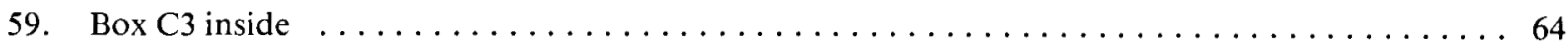

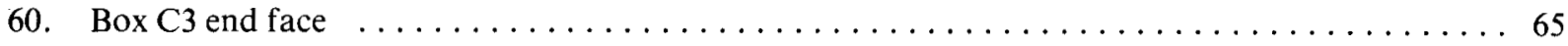

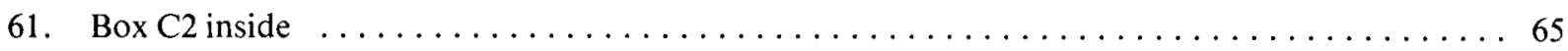




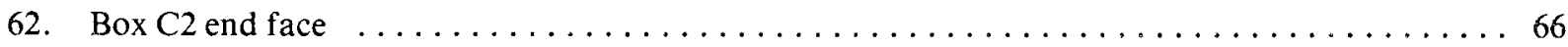

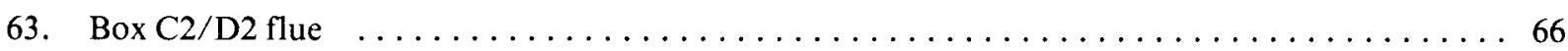

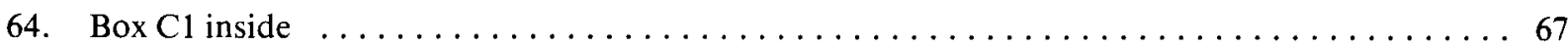

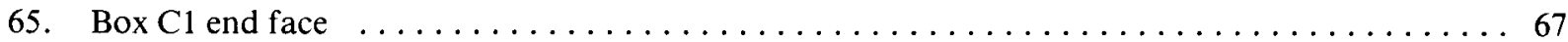

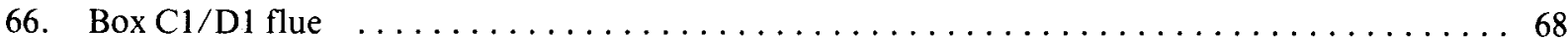

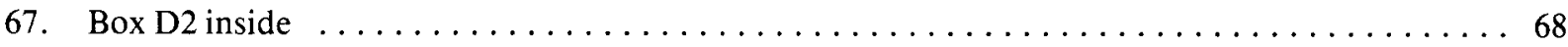

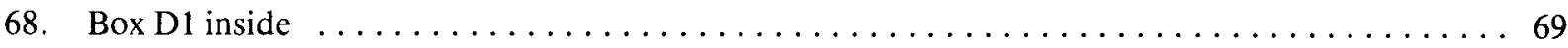

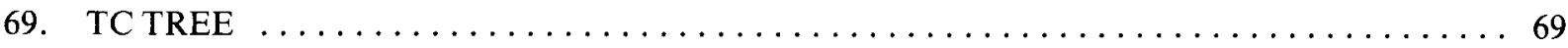

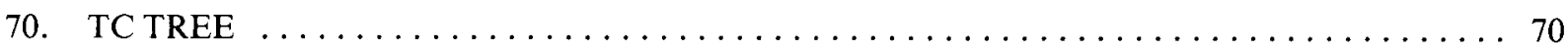

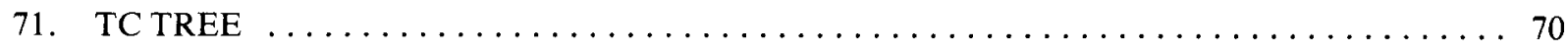

72. Fire Test 2, after test view of boxes in rows 1 and 2 , stacks 3 and $4 \ldots \ldots \ldots \ldots \ldots$

73. Fire Test 2, remains of the fire retardant barrier between drum rows 1 and 2 ,

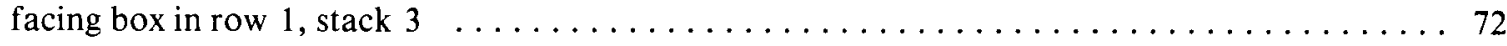

74. Fire Test 2 , after test view of inside corner after drum removal $\ldots \ldots \ldots \ldots \ldots \ldots \ldots \ldots$

75. Fire Test 2 , penetration in upper end corner of box in row 1 , stack $3 \ldots \ldots \ldots \ldots \ldots$

\section{TABLES}

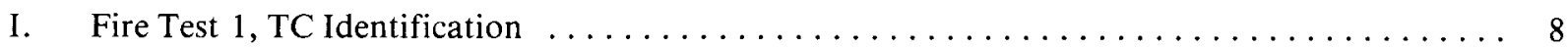

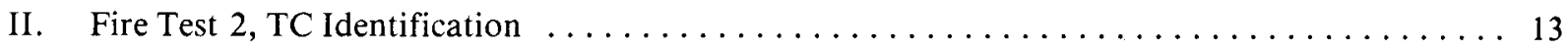

III. Fire Test 1 (Chronological Listing of Visual Observations) $\ldots \ldots \ldots \ldots \ldots \ldots \ldots \ldots$

IV. Fire Test 2 (Chronological Listing of Visual Observations) $\ldots \ldots \ldots \ldots \ldots \ldots \ldots$

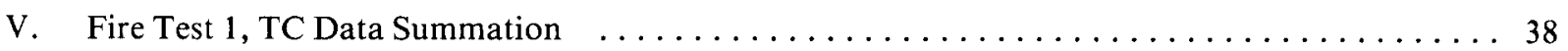

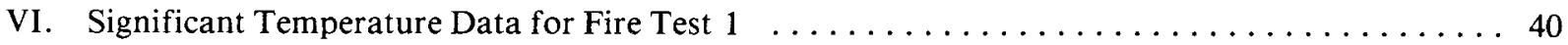

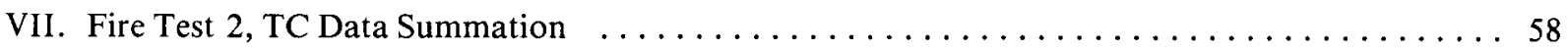

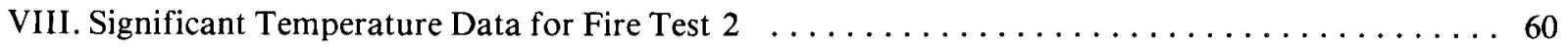




\section{DOT 7A FRP BOX FIRE TEST AT THE INEL}

\section{INTRODUCTION}

The Idaho National Engineering Laboratory (INEL) fire test was a joint venture between the Waste Management Program and Safety Division, EG\&G Idaho, Inc., INEL, Idaho; and the Nuclear Waste Engineering Division, Sandia Laboratory, Albuquerque, New Mexico. It was decided in discussions between the two laboratories that the INEL would be the lead lab on the fire test project.

Currently, DOT 7A FRP-containers (plywood boxes coated with roving strand fiber reinforced polyester) are being used to store waste contaminated with alpha emitting transuranic elements. Figure 1 shows the Transuranic Storage Area. Waste containers stored at the Radioactive Waste Management Complex (RWMC) are stacked inside the Air Support Weather Shield (ASWS) on an asphalt pad and in cells averaging approximately $45.7 \mathrm{~m}(150 \mathrm{ft}) \times 24.4 \mathrm{~m}(80 \mathrm{ft})$ and $4 \mathrm{~m}(13 \mathrm{ft})$ to $5 \mathrm{~m}(17 \mathrm{ft})$ high. The FRP-coated boxes are stacked in close array around the periphery of each cell. Steel drums and steel bins are stacked in the space bounded by the boxes. After a section of the cell has been filled, the ASWS is moved down the pad and a final covering of plywood, nylon reinforced polyvinyl chloride (PVC) and $0.6 \mathrm{~m}(2 \mathrm{ft})$ to $1 \mathrm{~m}(\sim 3 \mathrm{ft})$ of soil is applied over the waste. A similar stacking configuration to the aforementioned is being considered for the Waste Isolation Pilot Plant (WIPP). Because of this storage methodology, and the fact that no fixed fire suppression exists, questions about fire spread and growth among the waste containers of uncovered cells have been raised by the Department of Energy (DOE), Factory Mutual Engineering Association, and EG\&G Idaho, Inc., Waste Management and Safety Division personnel.

Other fire tests, such as the full-scale fire tests performed on the DOT 7A FRP-coated boxes at Southwest Research Institute ${ }^{1}$ (SWRI), have been conducted in the past. However, these past tests prompted questions that only further fire testing could answer with any degree of confidence. To outline a way to answer these questions, representatives of EG\&G Idaho, Inc., and Sandia Laboratories met at the Waste Management Programs-Operations (WMP-O) building at the INEL on November 30, 1978. Previous fire tests were discussed with relevance to both the RWMC and WIPP waste storage criteria. The conclusion of the discussion was that the previous tests did not address the events likely to occur at the RWMC and WIPP waste storage facilities. Therefore, additional fire tests were proposed and performed at the INEL on December 20 and 21, 1978 to investigate the DOT 7A FRP-coated box combustible characteristics when exposed to smaller ignition sources and storage configurations which include 208-1 (55-gal) steel drums. Figure 2 shows the present storage array used at the RWMC.

The full-scale fire tests conducted in June 1978, at SWRI, San Antonio, Texas, confirmed that the DOT 7A FRP-coated boxes would readily ignite, burn, and propogate fire through the storage array when exposed to a large source of 620.741 (164 gal) of \#2 diesel and gasoline mixed 50/50. These tests also revealed that the spacing involved in the stacking of waste containers creates various fire effects that had a pronounced bearing on both the intensity and propogation of the fire. Therefore, the size of the sources and the type of waste container configurations to be used for the two fire tests performed at the INEL was specified as follows. 


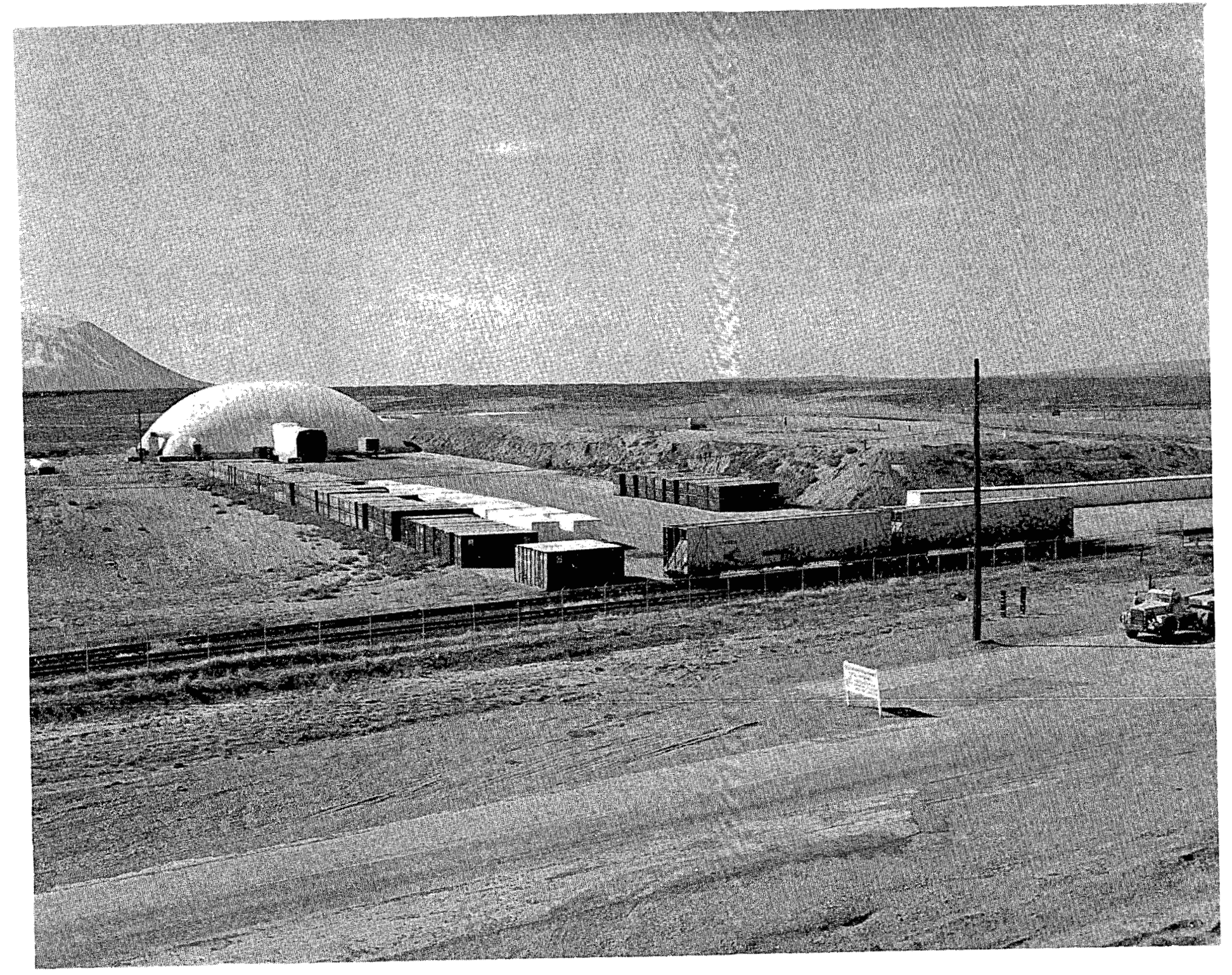

Fig. 1 RWMC transuranic storage area. 


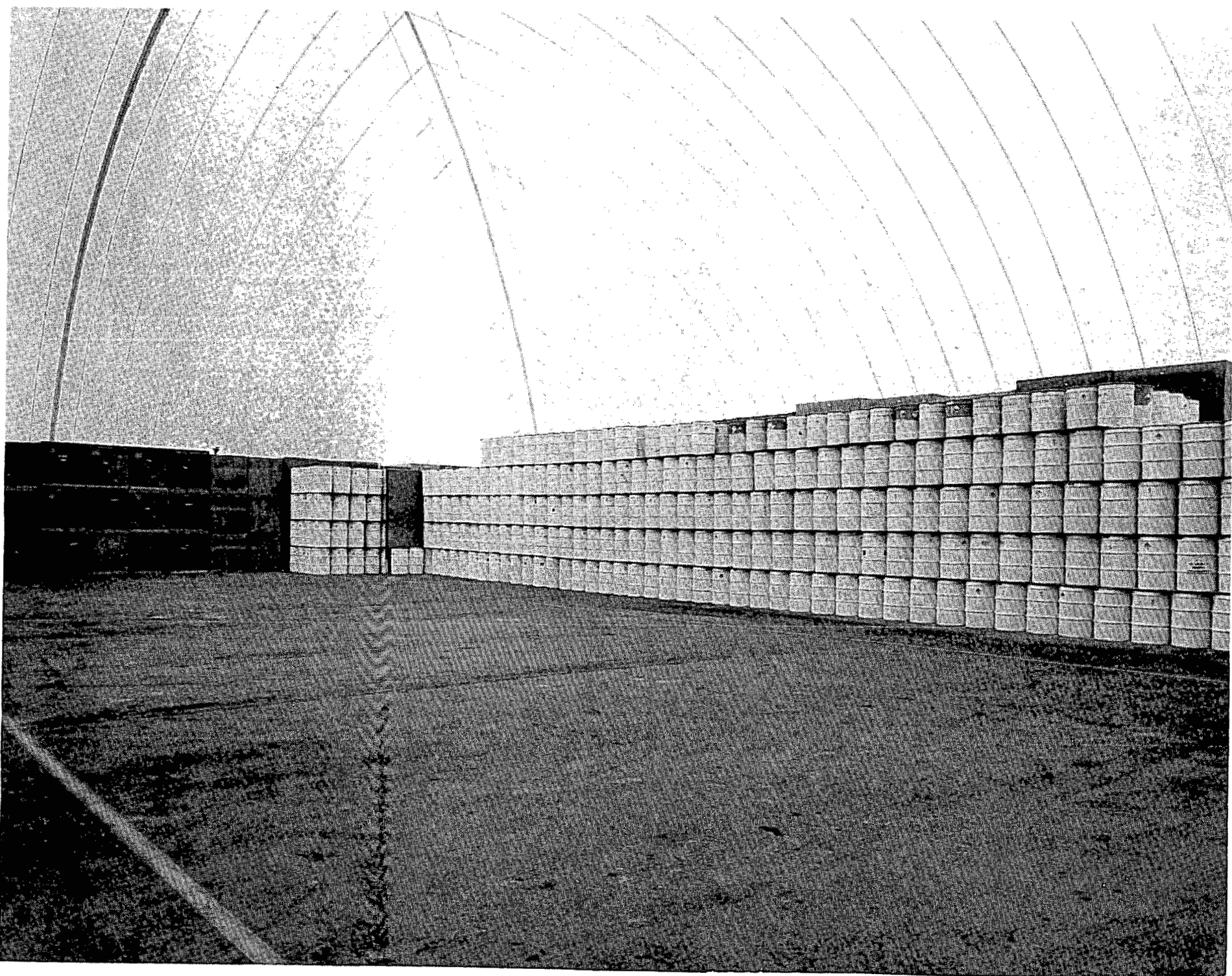

Fig. 2 RWMC transuranic waste storage configuration. 


\section{IGNITION SOURCE}

Fire Test 1 utilized 56.8 I (15 gal) of $\# 2$ diesel poured into a $1.83-\mathrm{m}$ (6-ft) square steel pan filled with salt (course and granulated mixed) to simulate a spill at the WIPP. The salt surface was also expected to pock as the fuel was spilled resulting in a pooling of free-standing fuel. This pooling effect was also thought to be representative of what would be expected in the RWMC environment. The fire source tests performed at Sandia Laboratory during October 1978, and the investigation of the maximum amount of fuel available in a single waste handling vehicle operating in the WIPP environment ${ }^{2}$, provided the basis for specifying the source size to be used. The size of the source is also considered likely for vehicles used at the RWMC.

Fire Test 2 utilized 15.1 l (4 gal) of \#2 diesel poured into a flat empty steel pan. Fifteen 1 (4 gal) of \#2 diesel, instead of the 56.81 ( 15 gal) used in Fire Test 1, is considered to be a credible spill for this test because the pan limits the spread of fuel that would generally accompany a 56.81 spill. Fifteen 1 (4 gal) of \#2 diesel spilled in a $1.83-\mathrm{m}(6-\mathrm{ft})$ square empty pan will provide a source $1.83 \mathrm{~m}(6 \mathrm{ft})$ square by $3.175 \mathrm{~mm}$ ( 0.125 in.) deep. It was calculated that a spill of 75.7 I (20 gal) of \#2 diesel, unbounded, would cover an area of approximately $4.8 \mathrm{~m}(-16 \mathrm{ft})$ square averaging $3.175 \mathrm{~mm}(0.125 \mathrm{in}$.) deep. Therefore, since this test bounds the flow of liquid to approximately $1.83 \mathrm{~m}(6 \mathrm{ft})$ square and the asphalt pads at the RWMC are sloped in such a way that an unbounded liquid spill would be expected to flow away from the waste, a small source of 15.11 ( $4 \mathrm{gal}$ ) of \#2 diesel concentrated at the most critical location of the storage array is considered to be a credible source for this test.

\section{WASTE CONTAINER CONFIGURATIONS}

The two configurations employed in the SWRI tests were two parallel rows, four boxes high and four boxes long, separated by an air space of approximately 9 in., and a corner array consisting of one row of boxes four high and three long butted against a second row of boxes four high and four long. Neither of these two arrays are common at the RWMC nor did they contain steel drums, which are commonly used as waste containers. Therefore, the experience gained in the SWRI test series established the need to further investigate fire characteristics of the DOT 7A FRP-coated boxes not only when they were exposed to a smaller source, but also when the storage configuration contained steel drums. Therefore, for the INEL fire tests, the DOT 7A FRP-coated box stacking arrangements would simulate the inside corner array used at the RWMC and anticipated for WIPP. Steel drums 2081 (55 gal) were placed in the inside corner of the array in an attempt to determine what effects the additional fire flue spaces and heat reflecting surfaces would have on the fire. The corner array is considered to be the most severe storage configuration existing in the present RWMC waste stacking array and in the proposed WIPP Project. 


\section{FIRE TEST SETUP AND INSTRUMENTATION}

Two tests were conducted. These tests were performed outdoors at the INEL Fire Department Training Ground. Ignition of the test arrays was achieved by the means of a diesel fuel fire. Both tests were documented using continuous closed circuit television and 35-mm color slides and photographs.

\section{FIRE TEST 1}

Fire Test 1 was set up in a corner array using four stacks of DOT 7A boxes. One stack, four boxes high and three stacks, three boxes high, is shown in Figure 3. Five unsealed 208-1 (55-gal) DOT 17C steel drums were positioned in a single level on the inside corner of the array as shown in Figure 4. The DOT 7A FRPcoated boxes were sealed and empty except for the thermocouple located in the inside center of each box. The DOT 17C steel drums contained $90-\mathrm{mm}$ rigid PVC liners, but were empty otherwise. A lid was placed on each drum, but the seal ring was omitted rendering the drums unsealed. As shown in Figure 4, the source pan on which the drums were set was completely full of crushed salt (coarse and granulated mixed) and extended approximately $0.61 \mathrm{~m}(2 \mathrm{ft})$ under the inside ends of the boxes in stacks 3 and 4 . ChromelAlumel thermocouples were located inside each box on center, in all flue spaces, on the ouside surface of selected boxes facing the fire, and on a thermocouple tree located in the source pan. The location of all thermcouples is shown in Figure 5 and described in Table $\mathbf{I}$. 


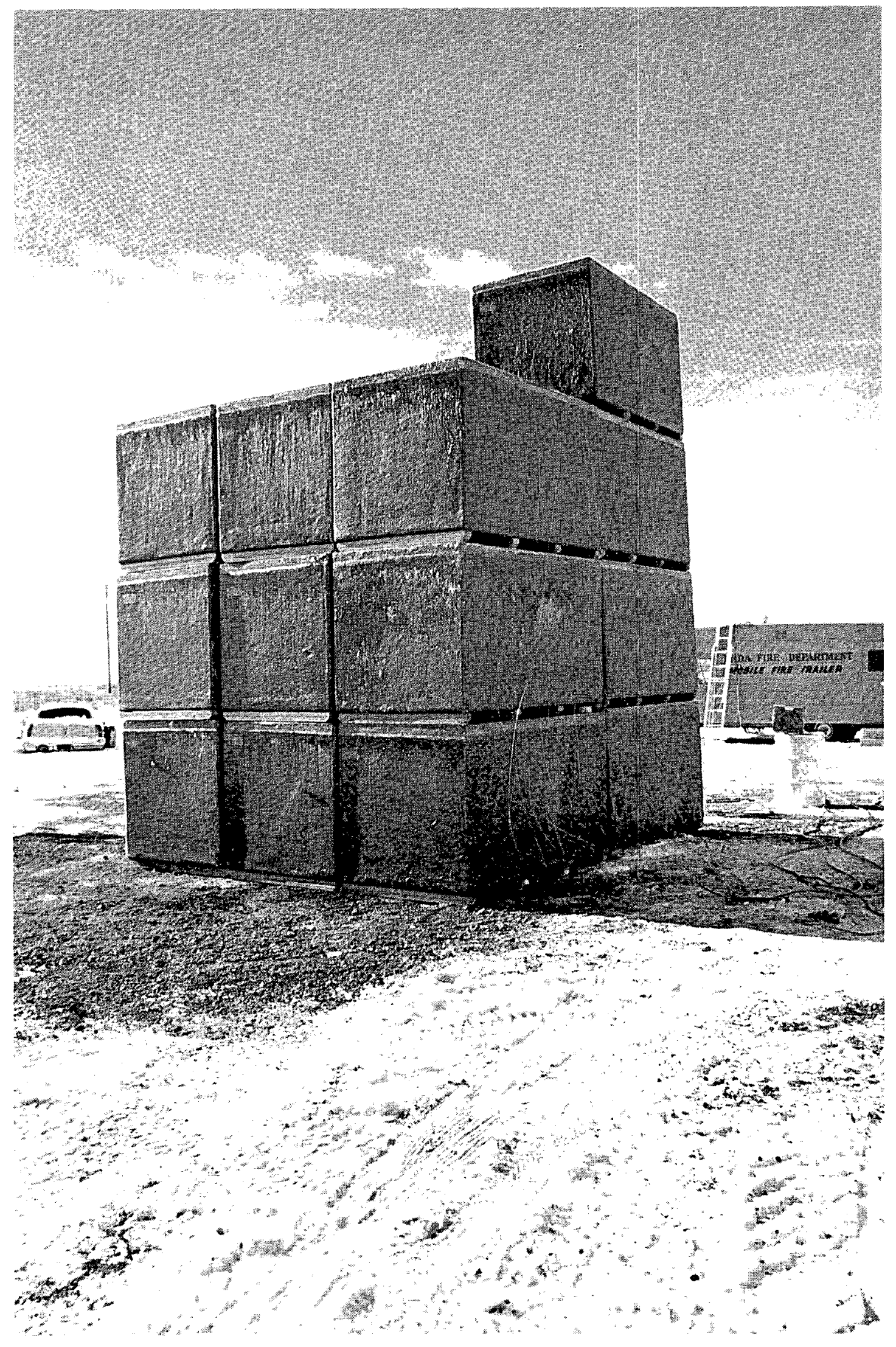

Fig. 3 Outside corner of test array - Fire Test 1. 


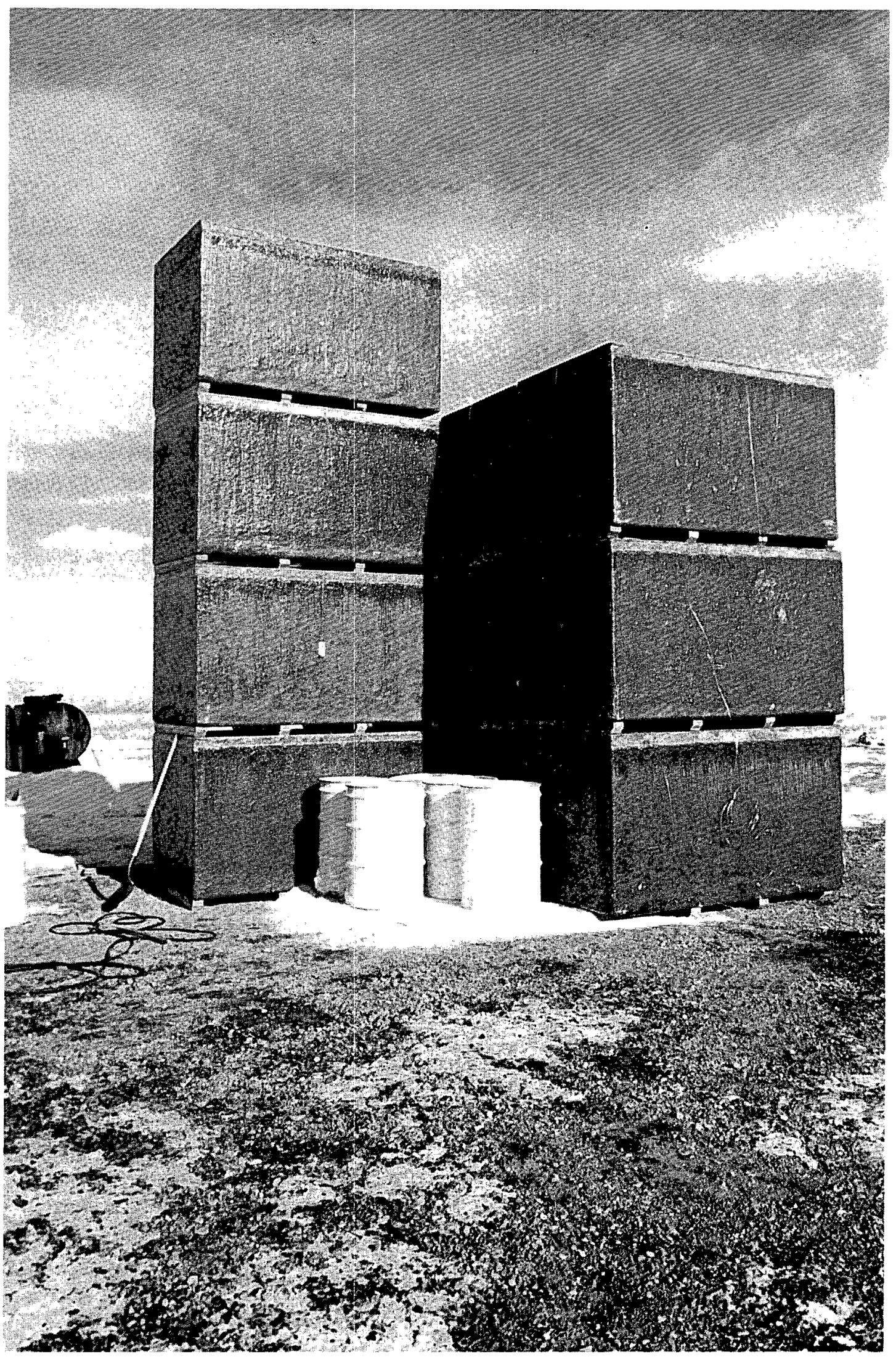

Fig. 4 Inside corner of test array - Fire Test 1. 


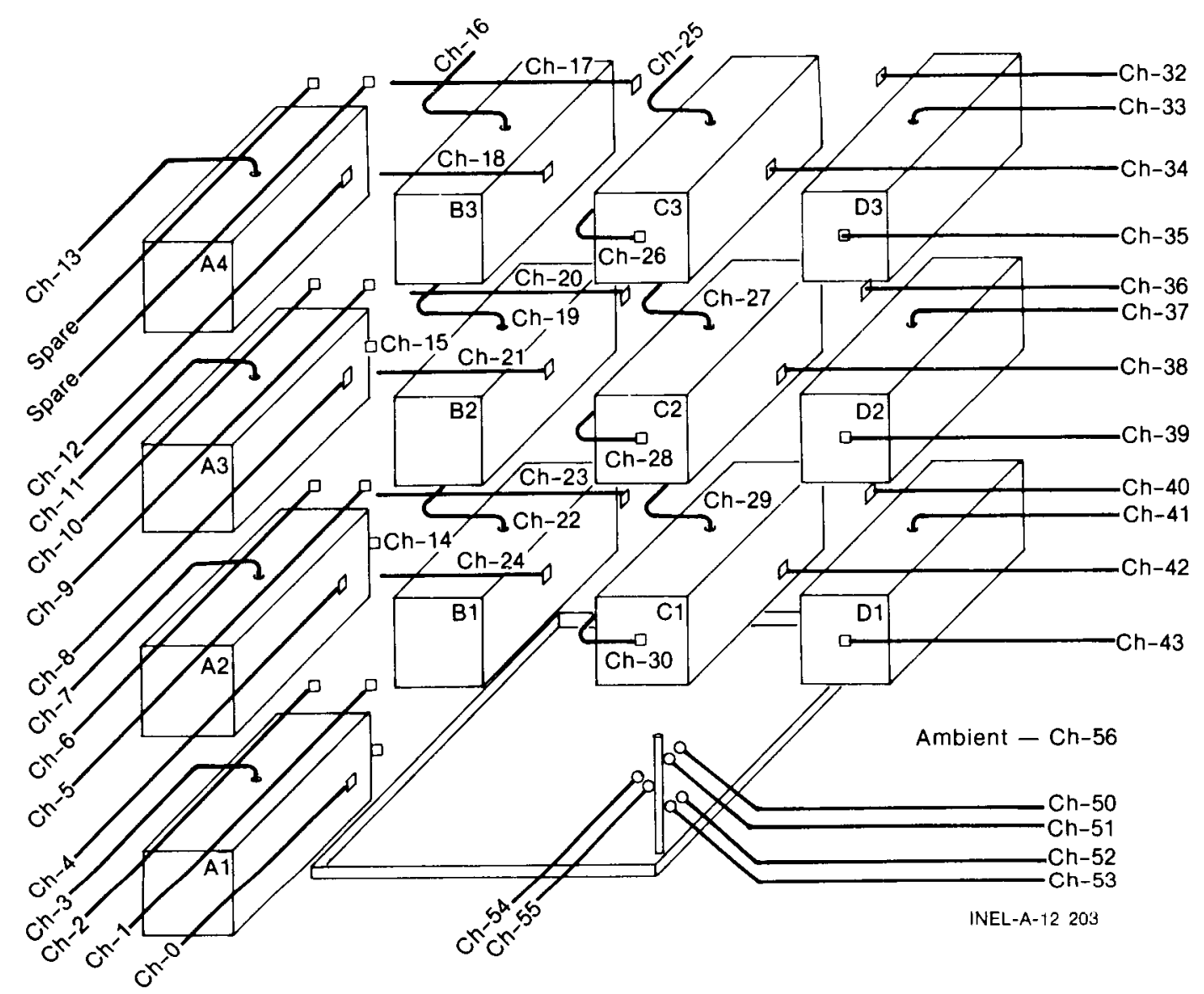

Fig. 5 Fire Test 1 TC locations.

TABLE I

FIRE TEST 1, TC IDENTIFICATION

Channe1 Number

0

1

2

3

4

5

6
TC Location

Al-Side

Al-Flue

Al-Flue

Al-Inside

A2-Side

A2-Flue

A2-Flue

A2-Inside

A3-side

A3-F1ue

A3-Flue

A3-Inside

A4-Side 
TABLE I (continued)

\begin{tabular}{|c|c|}
\hline Channe1 Number & TC Location \\
\hline 13 & A4-Inside \\
\hline 14 & B2-End corner \\
\hline 15 & B3-End corner \\
\hline 16 & B3-Inside \\
\hline 17 & B3-F1ue \\
\hline 18 & B3-F1ue \\
\hline 19 & B2-Inside \\
\hline 20 & B2-F1ue \\
\hline 21 & B2-F1ue \\
\hline 22 & B1-Inside \\
\hline 23 & B1-Flue \\
\hline 24 & Bl-Flue \\
\hline 25 & C3-Inside \\
\hline 26 & C3-End face \\
\hline 27 & C2-Inside \\
\hline 28 & C2-End face \\
\hline 29 & Cl-Inside \\
\hline 30 & $\mathrm{Cl}$-End face \\
\hline 31 & \\
\hline 32 & D3-Flue \\
\hline 33 & D3-Inside \\
\hline 34 & D3-Flue \\
\hline 35 & D3-End face \\
\hline 36 & D2-F1ue \\
\hline 37 & D2-Inside \\
\hline 38 & D2-F1ue \\
\hline 39 & $\mathrm{D}-2$ front \\
\hline 40 & D1-Flue \\
\hline 41 & Dl-Inside \\
\hline 42 & Dl-Flue \\
\hline 43 & D1-End face \\
\hline $50-55$ & Tree \\
\hline 56 & Ambient \\
\hline
\end{tabular}




\section{FIRE TEST 2}

Fire Test 2 employed both the same boxes and the source corner array used in the first fire test, as shown in Figure 6, with the exception that all boxes were rotated to expose the undamaged surface to the fire and the number of steel drums and their positioning. In Fire Test 2, 16 unsealed 208-1 (55-gal) DOT 7C steel drums were stacked into the inside corner of the array, four drums per level, four drums high, with each level separated by a $1.22-\mathrm{mm}(4-\mathrm{ft})$ square $\times 9.5 \mathrm{~mm}(3 / 8 \mathrm{in}$.) thick fire retardant plywood. All DOT $17 \mathrm{C}$ drums contained 90-mm rigid PVC liners except for the five drums reused from the first fire test; and these drums were positioned on the top of the stacks as shown in Figure 7. As in the first test, a lid was placed on each drum but the seal rings were omitted, rendering the drums unsealed. As shown in Figure 7, the source pan, in which the drums were placed, extends approximately $0.61 \mathrm{~m}(2 \mathrm{ft})$ under the inside ends of the boxes in stacks 3 and 4 . Unlike the first test, the source pan for this test was empty.

Chromel-alumel thermocouples were located inside each box on center, in all flue spaces, on the outside surface at selected boxes facing the fire, and on a thermocouple tree located in the source pan. The thermocouple locations for Fire Test 2 are shown in Figure 8 and described in Table II. 


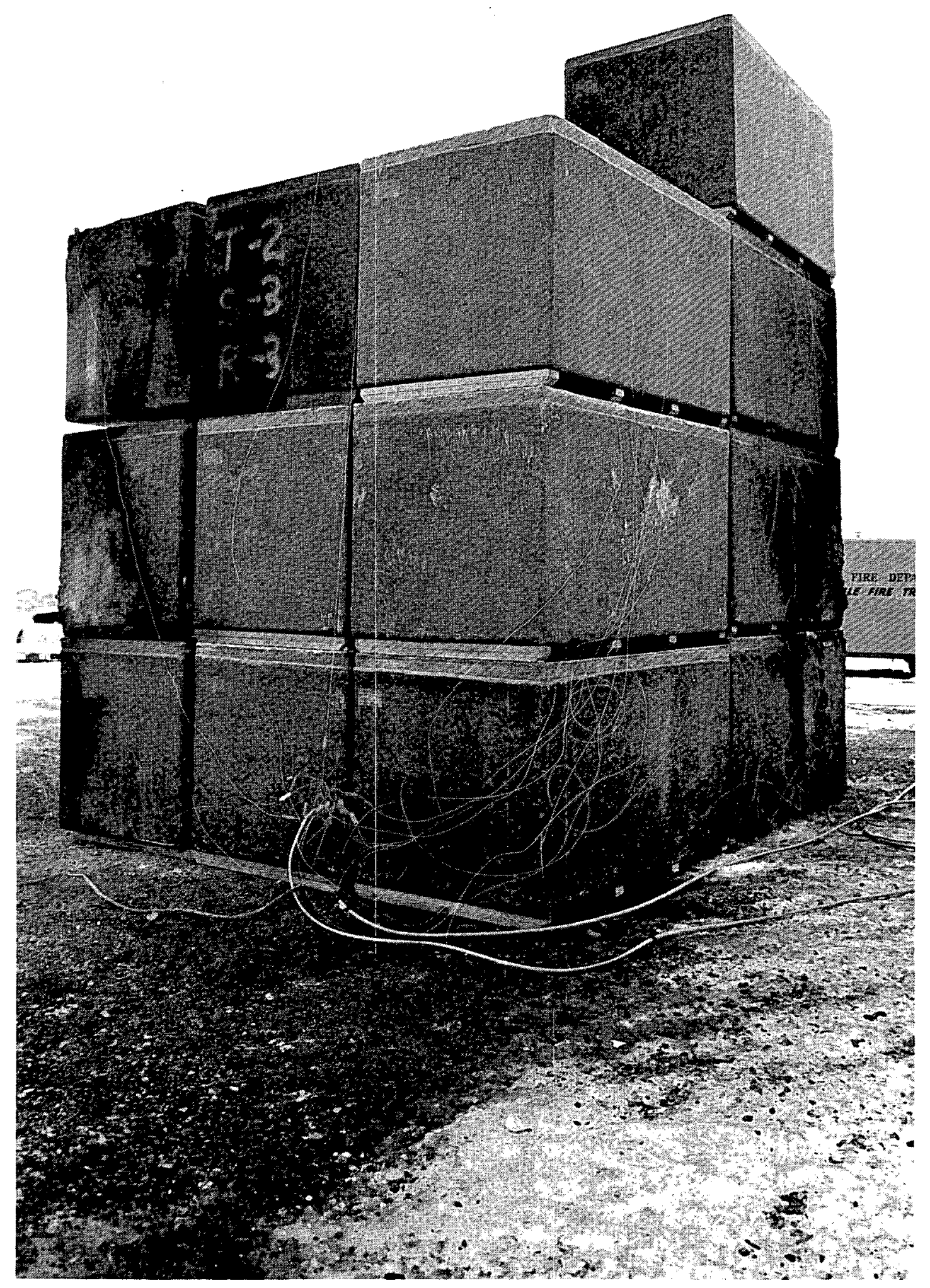

Fig. 6 Outside corner of test array - Fire Test 2. 


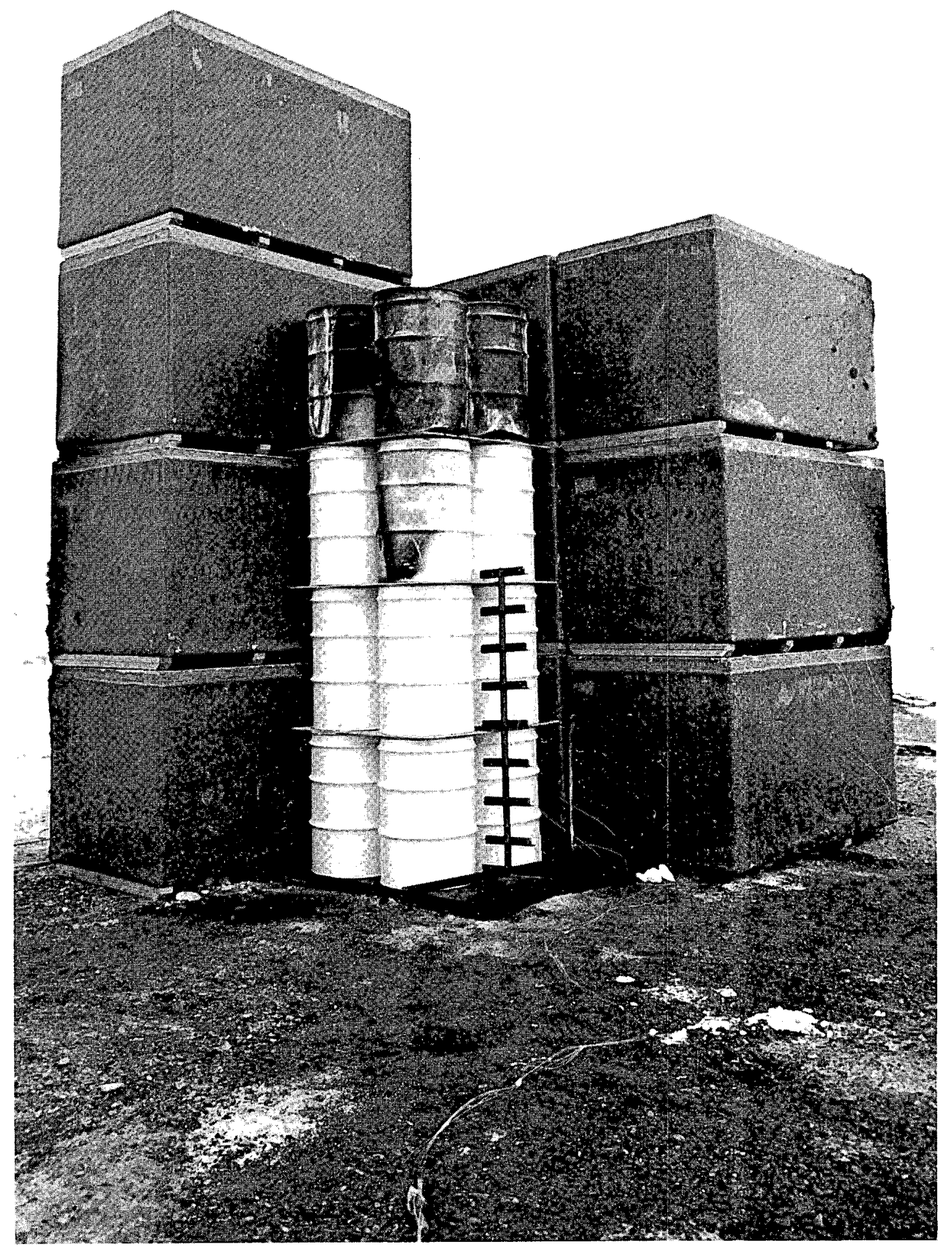

Fig. 7 Inside corner of test array - Fire Test 2. 


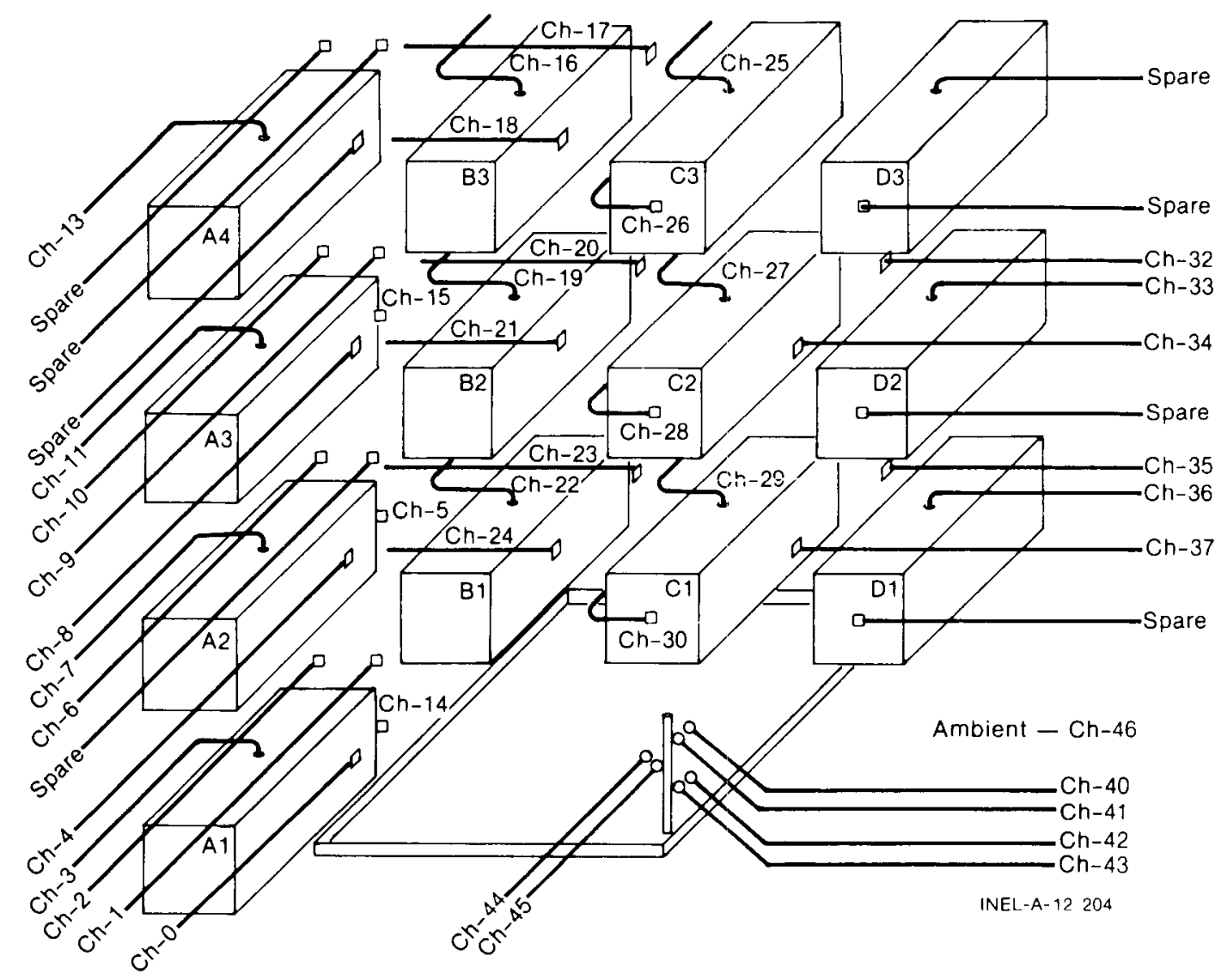

Fig. 8 Fire Test 2 TC locations.

TABLE II

FIRE TEST 2, TC IDENTIFICATION

Channel Number

0

1

2

3

4

5

6

7

8
TC Location

Al-Side

A1-F1ue

Al-Flue

A1-Inside

A2-Side

B2-End corner

A2-Flue

A2-Inside

A3-Side

A3-F1ue

A3-Flue

A3-Inside

A4-Side 


\section{Channel Number}

13

14

15

16

17

18

19

20

21

22

23

24

25

26

27

28

29

30

31

32

33

34

35

36

37

40-45

46
TC Location

A4-Flue

B1-End corner

B3-End corner

B3-Inside

B3-Flue

B3-F1ue

B2-Inside

B2-F1ue

B2-F1ue

B1-Inside

B1-Flue

B1-F1ue

C3-Inside

C3-End face

C2-Inside

C2-End face

Cl-Inside

Cl-End face

D2-F1ue

D2-Inside

D2-Flue

Dl-End face

D1-Inside

D1-Flue

Tree

Ambient 


\section{FIRE TEST PERFORMANCE}

\section{FIRE TEST 1}

The following final pretest preparations for Fire Test 1 were completed prior to 1400 hours on December 20, 1978:

(1) Approximately $600 \mathrm{lb}$ of mixed granulated and coarse salt placed in the source pan and smoothed out to completely fill the pan and overflow the outside edges of the pan

(2) Five 208-I (55-gal) DOT 17C steel drums with PVC liners were positioned on top of the salt and into the inside corner of DOT 7A FRP-coated box stacking array

(3) Following the completion of the container-stacking array, the final instrumentation continuity checks were completed

(4) At the completion of the instrumentation checkout, 56.78 I (15 gal) of \#2 diesel were poured into the source pan which completely saturated all the salt in the source pan.

At approximately 1400 hours on December 20,1978 the source was ignited initiating Fire Test 1 . The burn was allowed to continue until it was reasonably certain that sustained combustion of the DOT 7A FRP-coated boxes was achieved. After 40 min sustained combustion was thought to have been achieved on the boxes in rows 1 and 2 , stack 3 , and the fire was extinguished thereby saving the boxes from destruction so they could be reused for the second fire test.

Table III consists of a chronological listing of the visual observations made during Fire Test 1 and Figures 9 through 14 are selected pictorial views of the burn as it progressed to completion. Video tapes were also used to document the burn from start to finish.

The environmental conditions that existed at the burn site during the test were:

(1) Temperature: $-5.6^{\circ} \mathrm{C}\left(22^{\circ} \mathrm{F}\right)$

(2) Average relative humidity: $87 \%$

(3) Average wind velocity: $\sim 8.05 \mathrm{~km} / \mathrm{hr}(\sim 5 \mathrm{mph})$

(4) Wind direction: northeast ( $\sim 45$ degrees).

TABLE III

FIRE TEST 1

(Chronological Listing of Visual Observations)

Lapsed Time (min)

Observations

$0: 00$

Ignition of 非 diesel fuel and salt source.

$1: 00$ (Figure 9)

Fire starts to move into the flue spaces between barrels.

$2: 00$

Fire is visible in barrel flue spaces, flames about

$3 \mathrm{ft}$ high. 
Lapsed Time (min)

$3: 00$

4:00

$5: 00$

$6: 00$ (Figure 10)

$7: 00$

$8: 00$

$9: 00$

$10: 00$

$11: 00$

$12: 00$

$13: 00$

$14: 00$

$15: 00$

$16: 00$

$17: 00$

$18: 00$
Observations

Fire is approximately the same as $2 \mathrm{~min}$.

Drums begin releasing excess pressure, flames increase to approximately 4 to $5 \mathrm{ft}$ high.

Fire is approximately the same size, smoke beginning to exit from within the barrels from vaporization of the poly liners.

Drum popped, several drums smoking heavily, flames are approximately 6 to $7 \mathrm{ft}$ high, but still mainly within drum flue space.

Salt is popping and crackling, small flames are exiting from inside the drums, smoke light to moderate and black in color.

Fire conditions about the same. All five drums have popped.

Fire conditions about the same.

White wisps of smoke are released from the drums, flames have reduced in size; however, the fire is starting to progress toward the boxes.

Same conditions as 10:00 min.

Fire is about the same as 11:00 min, but more flame is being released from the drums due to vaporization of the PVC liners. Smoke density is light.

Fire is about the same -- small, slow, quiet flames -- black smoke increasing in denisty.

Fire conditions about the same.

Fire conditions about the same.

Fire conditions about the same, fire progressing out of drum flues toward boxes.

Fire conditions about the same.

Fire progressed to boxes in stacks 1 and 3 , flames beginning to increase in height 5 to $6 \mathrm{ft}$. Liners in drums are burning intensely. 
Lapsed Time (min)

$19: 00$

$20: 00$

$21: 00$

$22: 00$

$23: 00$

$24: 00$

$25: 00$

$26: 00$

$27: 00$

$28: 00$

$29: 00$

$30: 00$

$31: 00$

$32: 00-36: 00$

(Figure 11)
Observations

Fire is against the boxes in stacks 1 and 3 ; boxes in row 1 , stacks 1 and 3 are beginning to sweat.

No change.

No change.

No change.

Row 1, stack 1, flame flashing from vaporized resin commencing on the box face opposite the drum. Fire increasing slightly -- smoke density still light.

No change.

Row 1, stack 1: flames are visible along the box face.

Row 1, stack 3: flame flashing from vaporized resin commencing on the box face opposite the drum. Fire intensity increasing slightly. Smoke density still light to moderate but blackening in color.

Boxes in row 1 , stacks 1 and 3 are visibly burning along the face particularly in the vicinity of the drums .

Runners on box row 2, stacks 1 burning, face of boxes in row 1 stacks 1 and 3 are burning more intensly. Smoke density is moderate and black in color.

Fire continues to grow. Three fire sources are visible: (1) source fire, (2) fire from top of drums, (3) fire from the face of the boxes. Smoke black in color. Boxes in row 2, stacks 1 and 3 are beginning to flash due to resin vaporization.

Fire about the same.

No change.

Boxes in rows 1 and 2 , stacks 1 and 3 are burning along the face, still have a three source fire with flames 8 to $10 \mathrm{ft}$ high. Smoke density about the same. 


\begin{tabular}{|c|c|}
\hline Lapsed Time (min) & Observations \\
\hline $\begin{array}{l}32: 00-36: 00 \\
(\text { continued })\end{array}$ & $\begin{array}{l}\text { Fire about the same with flames } 8 \text { to } 10 \mathrm{ft} \text { high. } \\
\text { Box faces in rows } 1 \text { and } 2 \text {, stacks } 1 \text { and } 3 \text { burning } \\
\text { intensely. Fire was considered to be in sustained } \\
\text { combustion at the end of this time period. }\end{array}$ \\
\hline $37: 00$ (Figure 12) & $\begin{array}{l}\text { The Halon } 1211 \text { fire suppression system was armed } \\
\text { and the fire eye released the extinguishing agent } \\
\text { at this time. However, due to the slight breeze, } \\
\text { distance and misalignment, the Halon } 1121 \text { did not } \\
\text { extinguish the fire although it did reduce it } \\
\text { somewhat in size. }\end{array}$ \\
\hline $38: 00$ & The fire began to increase in intensity. \\
\hline 39:00 (Figure 13) & $\begin{array}{l}\text { The fire is about the same as it was at } 36 \mathrm{~min} \text {, } \\
\text { rows } 1 \text { and } 2 \text {, stacks } 1 \text { and } 3 \text { box faces burning. }\end{array}$ \\
\hline $40: 00$ & $\begin{array}{l}\text { The RWMC fire brigade was directed to extinguish } \\
\text { the fire. }\end{array}$ \\
\hline 41:00 (Figure 14) & $\begin{array}{l}\text { The fire was extinguished using an estimated } \\
94.61(25 \mathrm{gal}) \text { of water. }\end{array}$ \\
\hline
\end{tabular}




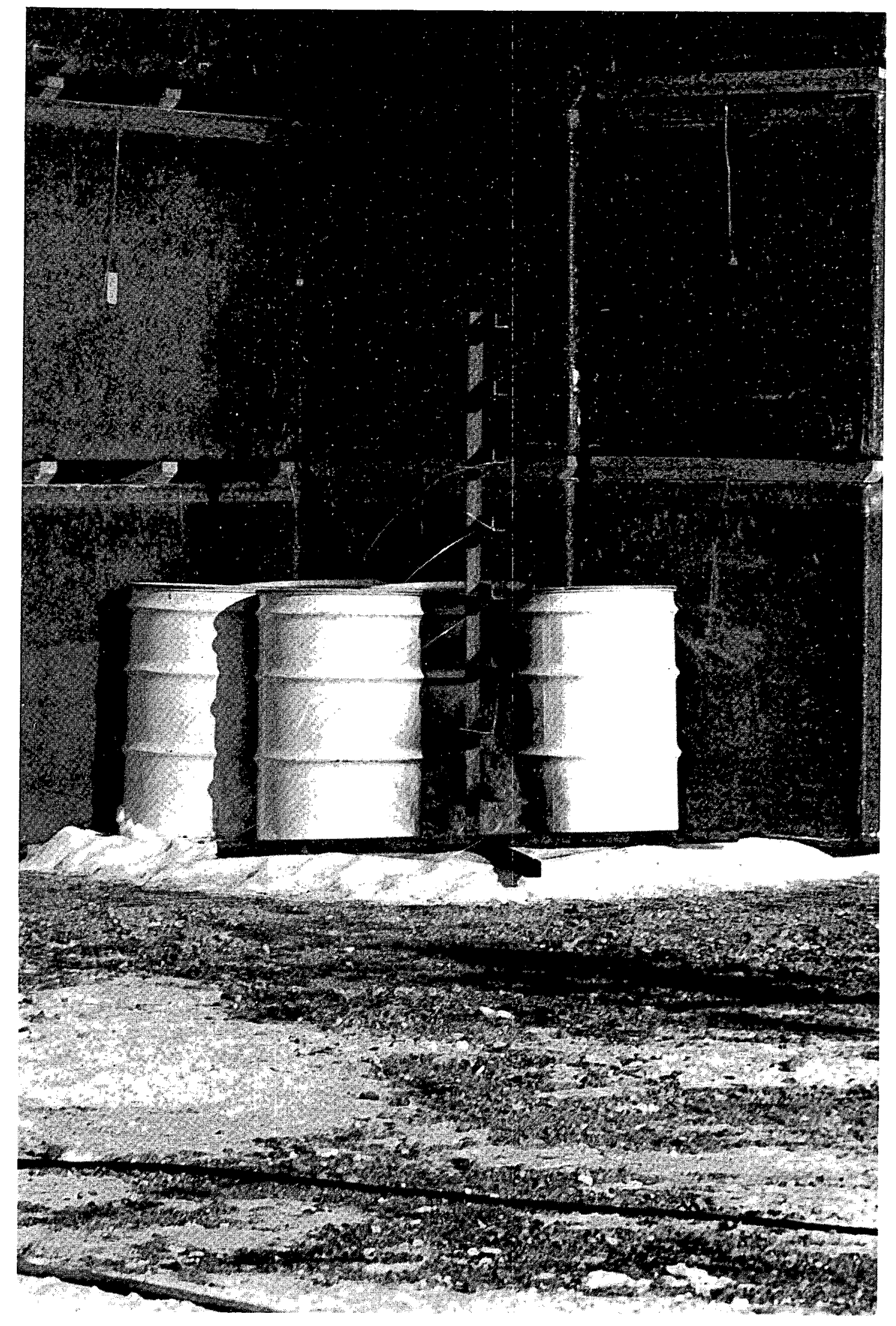

Fig. 9 Fire Test 1, time $1 \mathrm{~min}$. 


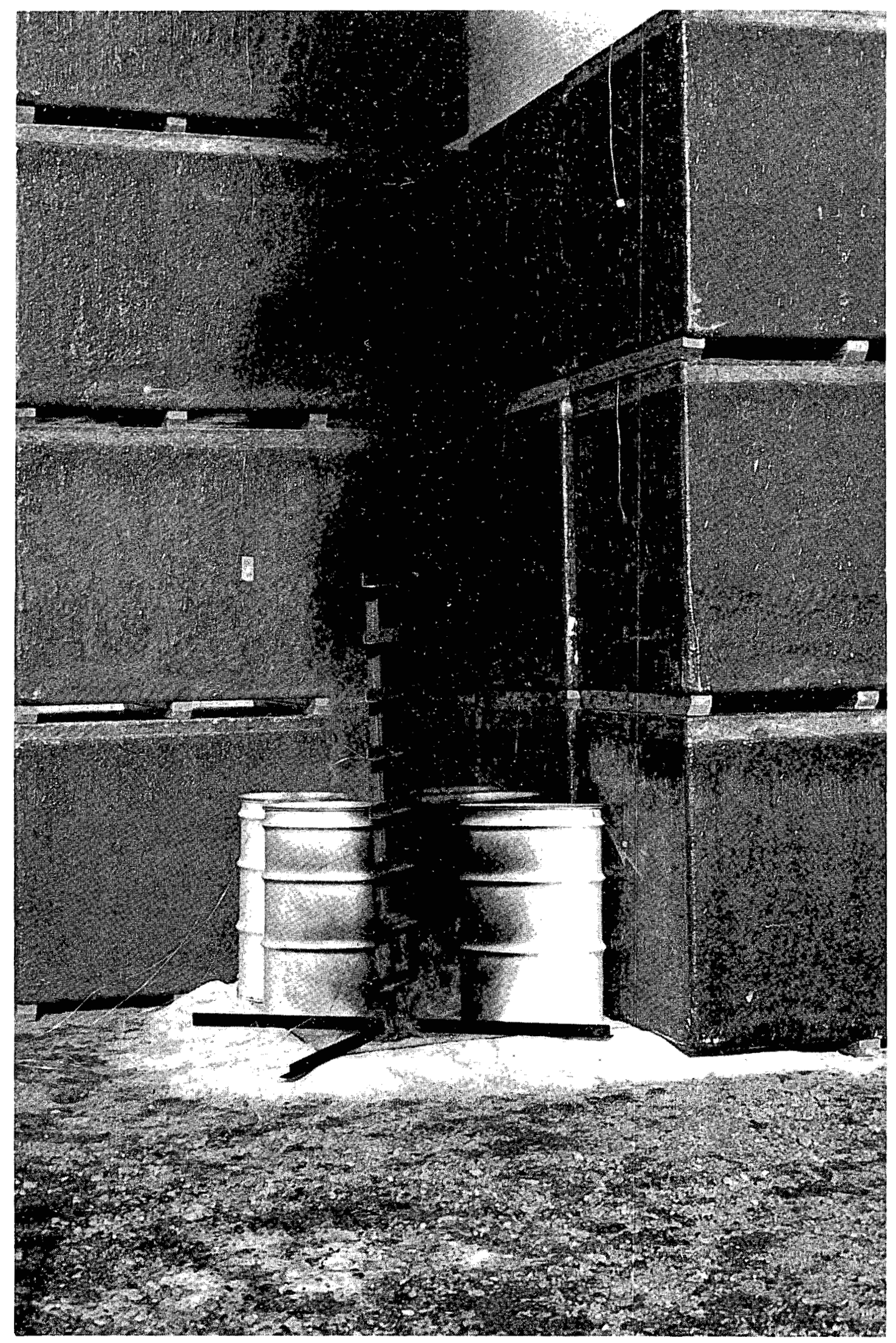

Fig. 10 Fire Test 1, time $6 \mathrm{~min}$. 


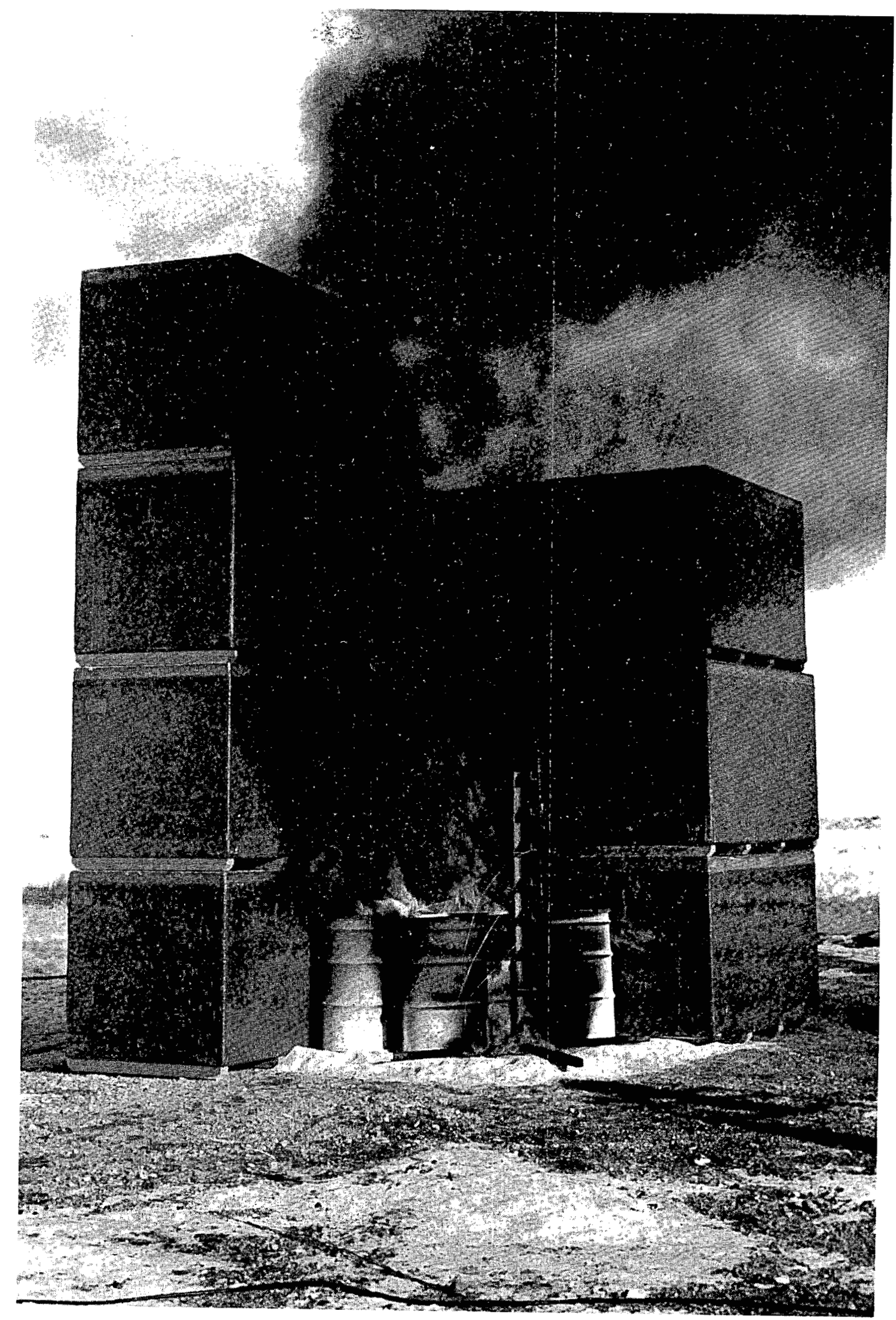

Fig. 11 Fire Test 1, time $32 \mathrm{~min}$. 


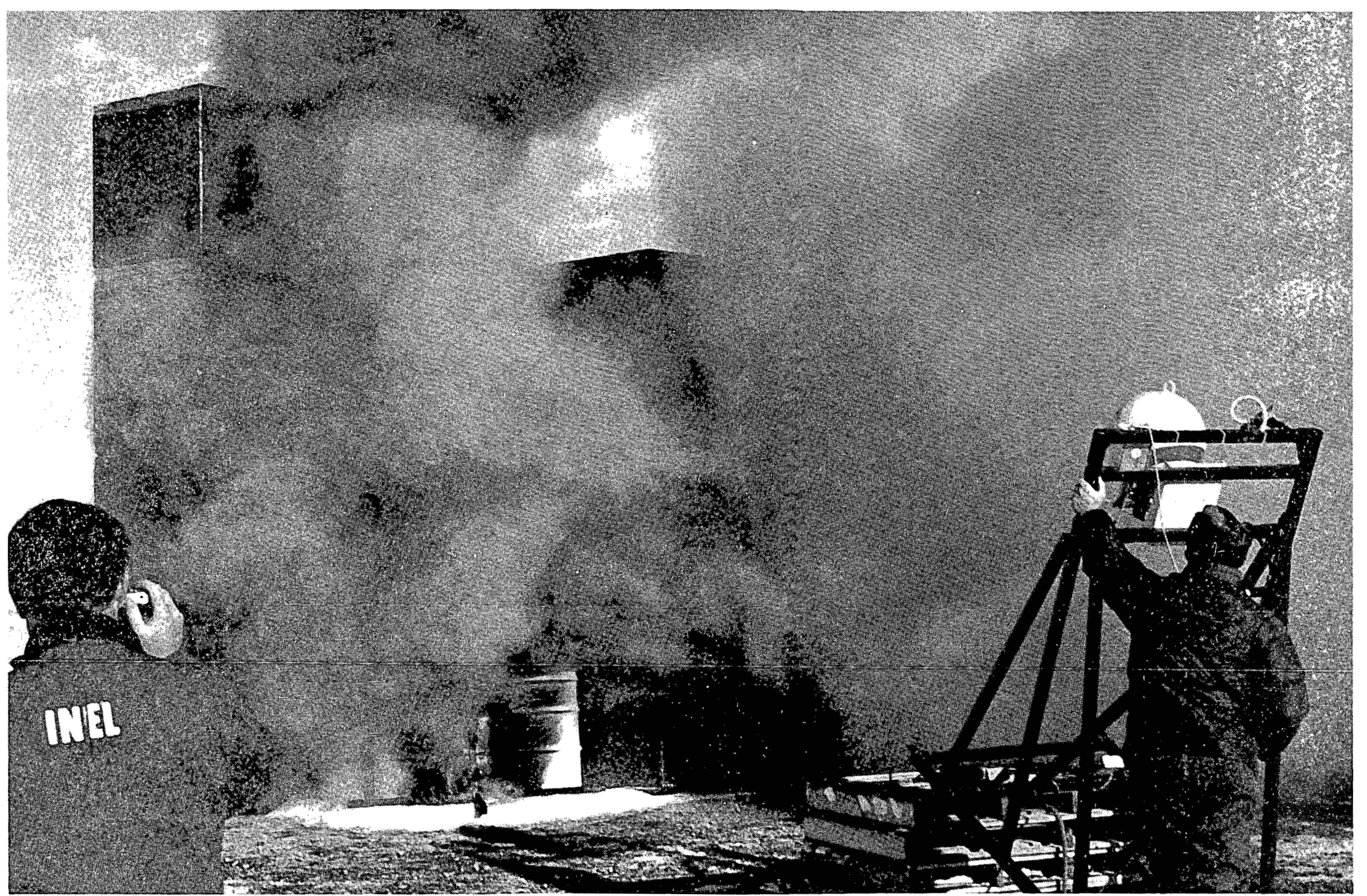

Fig. 12 Fire Test 1, time $37 \mathrm{~min}$ (Halon System).

(1) 


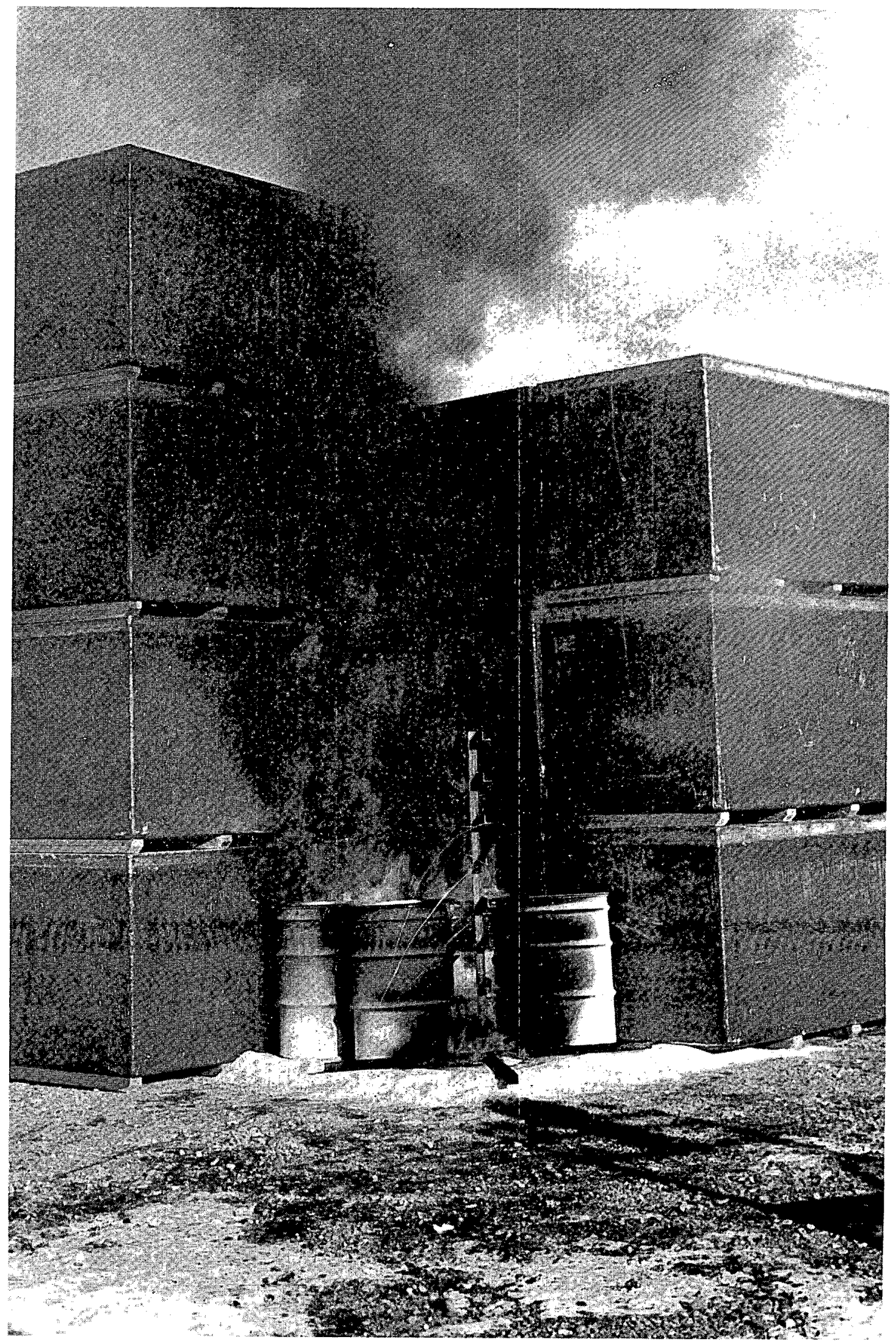

Fig. 13 Fire Test 1, time $39 \mathrm{~min}$. 


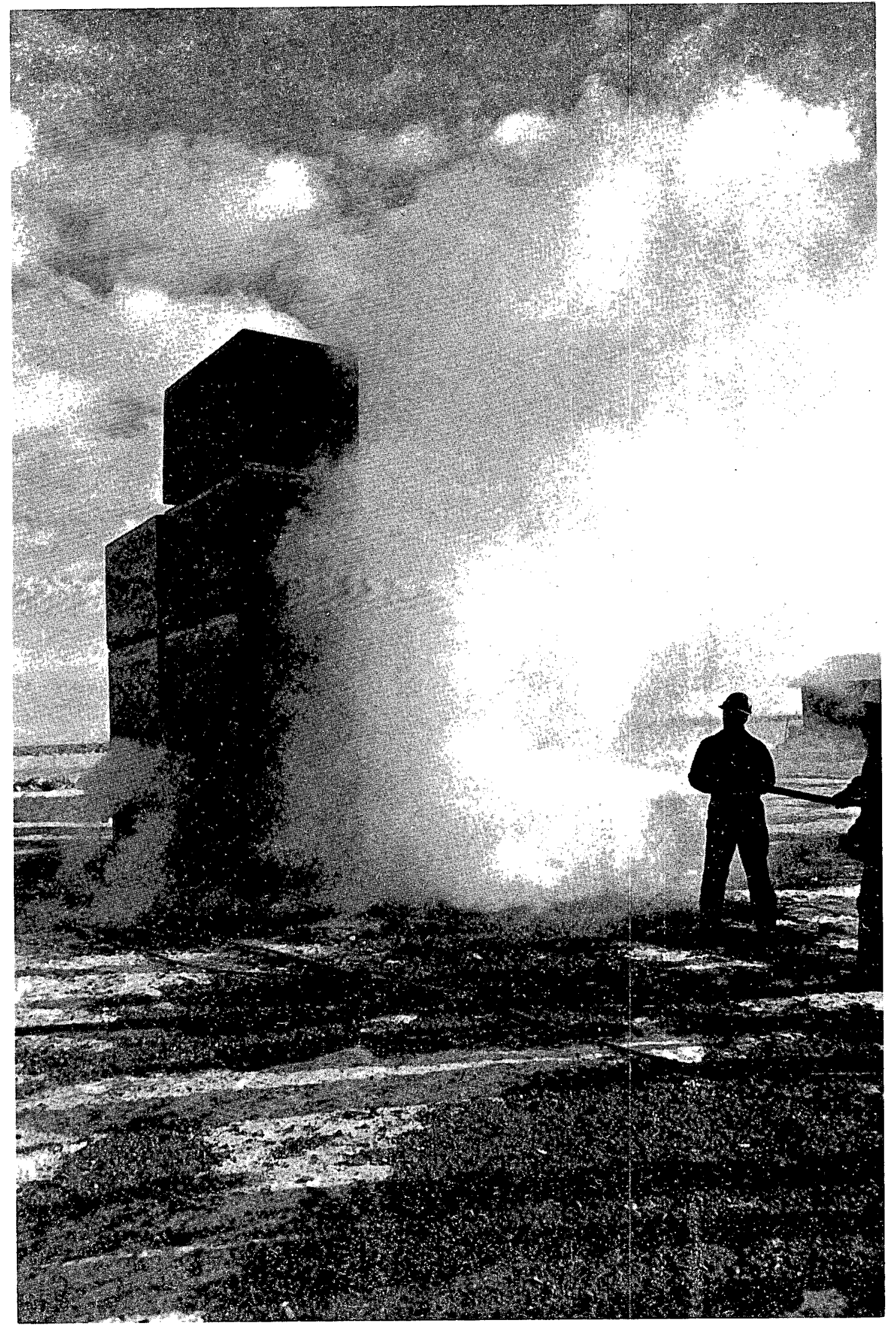

Fig. 14 Fire Test 1, time $41 \mathrm{~min}$. 


\section{FIRE TEST 2}

Fire Test 2 used the same DOT 7A FRP-coated boxes that were used in the first fire test, except they were rotated 180 degrees so that undamaged surfaces would be exposed to the fire. The second fire test also employed the same box stacking configuration as the first fire test with the main difference between the two configurations being the number of DOT $17 \mathrm{C}$ steel drums employed.

The following final pretest preparations for Fire Test 2 were completed prior to 1400 hours on December 21, 1978.

(1) The source pan was emptied of both the salt and remaining \#2 diesel from the first fire test and repositioned into the inside corner of the restacked DOT 7A FRP-coated boxes

(2) Sixteen 208-1 (55-gal) DOT 17C steel drums were stacked into the inside corner of the boxes; four drums per level and four drums high. A piece of fire retardant plywood $1.22 \mathrm{~m}(4 \mathrm{ft})$ square $\times 0.95 \mathrm{~cm}(0.375 \mathrm{in}$. $)$ thick separated each level of drums

(3) Following the completion of the container stacking array, the final instrumentation checkout was completed

(4) At the completion of instrumentation checkout, 15.141 (4 gal) of \#2 diesel was poured into the source pan.

At approximately 1405 hours on December 21,1978 , the source was ignited initiating Fire Test 2 . Since this was to be the last test performed, it had been decided that the burn would be allowed to burn until it either destroyed the boxes or self extinguished. This burn lasted for approximately $75 \mathrm{~min}$ before it burned itself out.

Table IV consists of a chronological listing of the visual observations made during Fire Test 2 and Figures 15 through 23 are selected pictorial views of the burn as it progressed to its conclusion. Video tapes were also used to document the burn from start to finish.

The environmental conditions that existed at the burn site during the test were:

(1) Temperature: $-5.6^{\circ} \mathrm{C}\left(22^{\circ} \mathrm{F}\right)$ average

(2) Average relative humidity: $87 \%$

(3) Wind velocity: approximately $8.05 \mathrm{~km} / \mathrm{hr}(\sim 5 \mathrm{mph})$

(4) Wind directon: northeast (approximately 45 degrees). 
$\underline{\text { TABLE IV }}$

FIRE TEST 2

(Chronologica1 Listing of Visual Observations)

\section{Lapsed Time (min)}

$0: 00$

$1: 00$ (Figure 15)

2:00 (Figure 16)

3:00 (Figure 17)

$4: 00$

$5: 00$

$6: 00$

7:00 (Figure 18)

$8: 00$

$9: 00$

$10: 00$

$11: 00$
Observations

Ignition of 非 2 diese1 fuel source.

Smal1, quiet fire -- outer corner of source pan.

Flames spread all over the outer edges and corner of source pan, starting into the drum flue spaces and against box row 1 , stack 4. Smoke density light to moderate.

Skids on box in row 1, stack 4 starting to periodically flash. Flames increase to approximately $7 \mathrm{ft}$ in height. Fire spread around pan perimeter and against box row 1 , stack 1 . Smoke density the same.

Row 1, stack 4 box face beginning to flash flame from resin vaporization. Skids of box row 2, stack 4 burning.

Lids on the drums begin releasing, fire appears to have progressed through the barrel flue spaces back against the boxes in the corner.

Fire and smoke about the same, face on box row 1 , stack 1 burning.

Fire mostly along box facings in stacks $1,2,3$, and 4. Skid on box row 2 , stack 4 beginning to flash.

Fire about the same, skid on box row 2, stack 4 burning.

Fire concentrated mainly in stacks 3 and 4, drums still releaving, smoke light to moderate. Fire retardant barrier burning.

Flames are intense between the boxes in row 1 , stacks 3 and 4 and the first leve 1 of drums.

Fire is intense at the base of the boxes row 1 , stacks 3 and 4 . 
Lapsed Time (min)

12:00 (Figure 19)

$13: 00$

$14: 00$

$15: 00$

$16: 00$

$17: 00$

$18: 00$

$19: 00$

20:00 (Figure 20)

$21: 00$

$22: 00$

$23: 00$

$24: 00$

$25: 00$

$26: 00$
Observations

Fire still concentrated along stacks 3 and 4, source flame in pan diminishing. Resin vaporized flame along boxes -- drums still releaving. Flames still visible in drum flue spaces.

No change.

No change.

Source fire appears gone. Flames concentrated on the box faces, rows 1 and 2, stacks 3 and 4. Main intensity appears directly opposite the drum facings.

No change.

Fire remains about the same, but appears to be slowly losing some intensity.

Fire burning from underneath box row 1 , stack 4 . Face of boxes in rows 1 and 2 , stacks 3 and 4 burning. Fire concentrated mainly along the box faces opposite the drums.

Fire beginning to diminish in intensity on box faces rows 1 and 2 , stacks 3 and 4 , between the box faces and drum faces.

Fire quiet, dying down; flame still coming from under box in row 1 , stack 4 . White smoke being emitted from under box row 1 , stack 4 .

No change except fire continues to die down.

Boxes in rows 1 and 2 , stacks 3 and 4 still involved but fire continues to die down. Smoke and flame still under box row 1 , stack 4 .

No change.

Fire continues to die down.

Fire continues to die down. Boxes in rows 1 and 2 , stacks 3 and 4 involved.

Fire continues to ' 1 ose intensity. 
$\underline{\text { Lapsed Time (min) }}$

$27: 00$

$28: 00$

$29: 00$

$30: 00$

31:00 (Figure 21)

$32: 00$ to $39: 00$

40:00 to $44: 00$

(Figure 22)

$45: 00$ to $47: 00$

$48: 00$

49:00 to $59: 00$

(Figure 23)

$60: 00$ to $69: 00$

$70: 00$

$75: 00$

$75: 30$
Observations

Fire subsided to a narrow flame along the box face in rows 1 and 2 and stack 3 . Small flame and smoke persist from under box in row 1 , stack 4 .

No change.

No change.

No change.

Fire continues to subside on the box faces of rows 1 and 2 , stack 3 . No flame visible under box row 1 , stack 4 .

Fire continues to subside -- small narrow flame between the drum faces in levels 1 and 2 and box faces rows 1 and 2 , stack 3 .

Sma11 narrow flame persists on the face of box row 1 , stack 3 opposite the drum face.

Small flames are visible within the burned fiberglass, probably wood fire. Very quiet fire.

Inside corner of skid on box row 1 , stack 1 still has a very small flickering flame similar to a candle.

Flames on the box face row 1 , stack 3 appear to have gone out. Skid on box row 1, stack 1 still f1ickering.

Skid still flickering but very small. No flame has reappeared from any of the boxes.

Very small flame continues to flash (goes out then reappears) on skid box row 1 , stack 1 . No other flames apparent al though the skids on box row 2, stacks 3 and 4 continue to smolder.

All flames are out, no $\mathrm{flame}$ is apparent anywhere. Small wisps of white smoke periodically emitted from the smoldering skids on boxes row 2 , stacks 3 and 4 .

Test terminated. 


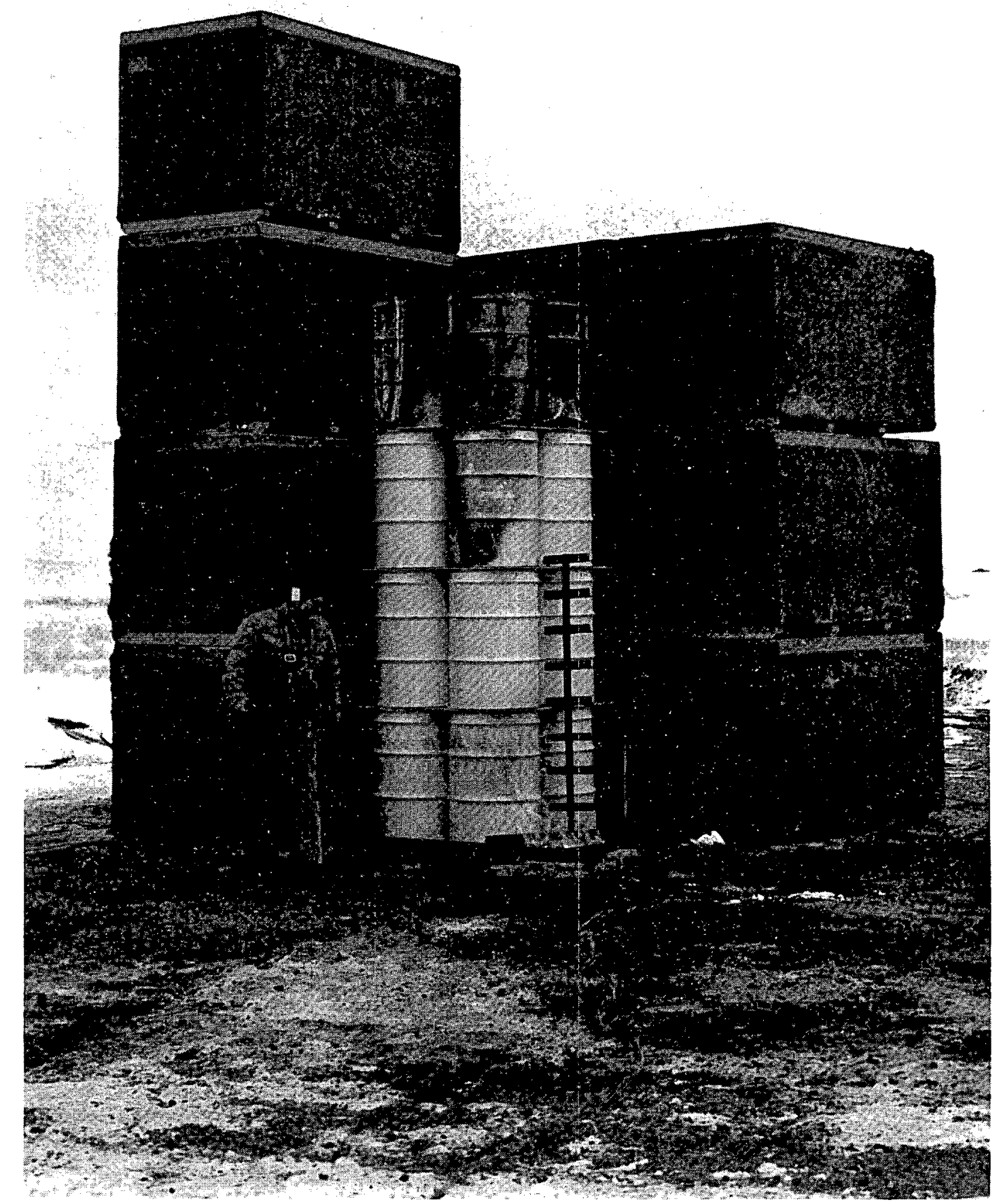

Fig. 15 Fire Test 2, time $1 \mathrm{~min}$. 


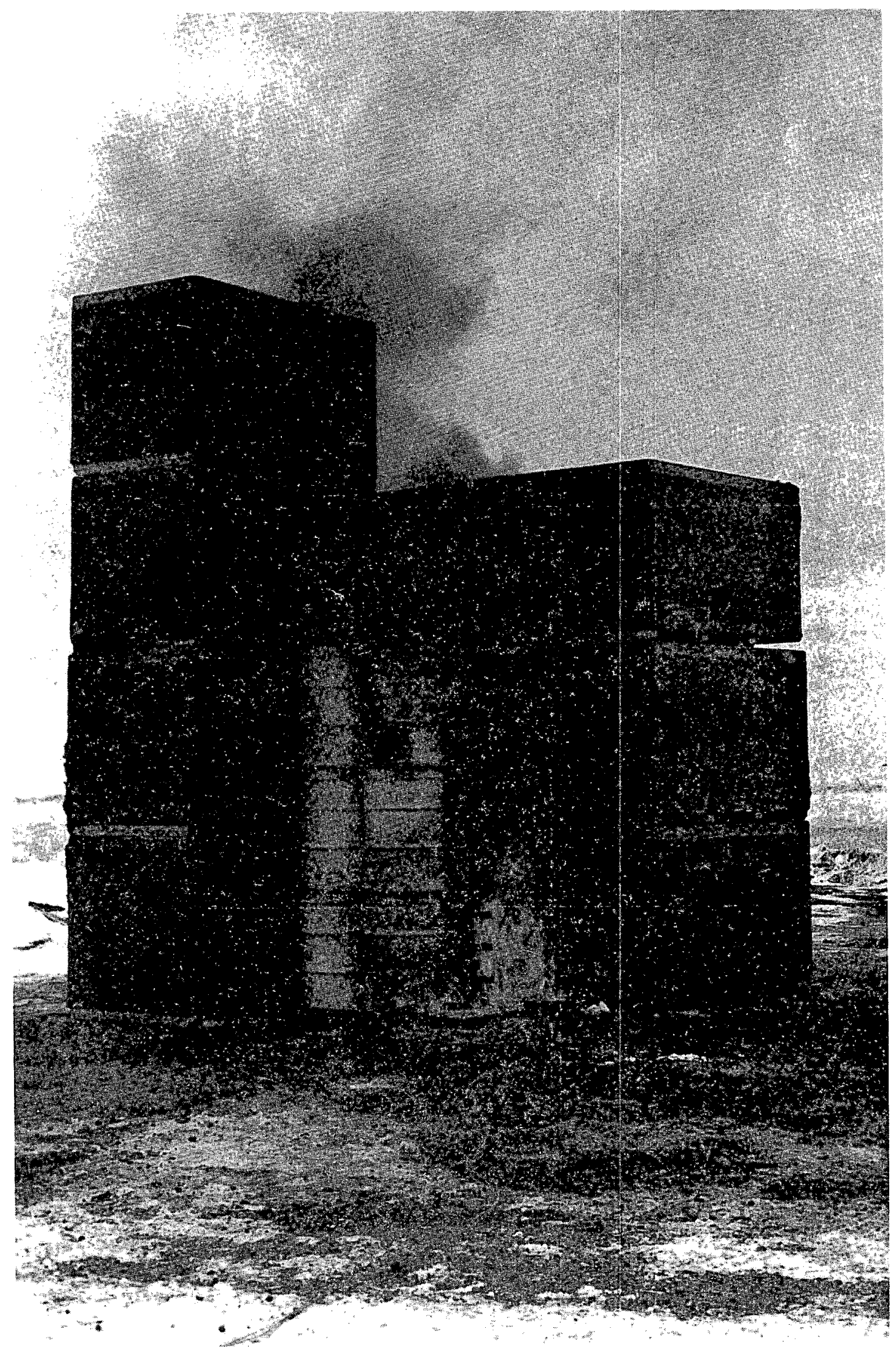

Fig. 16 Fire Test 2, time $2 \mathrm{~min}$. 


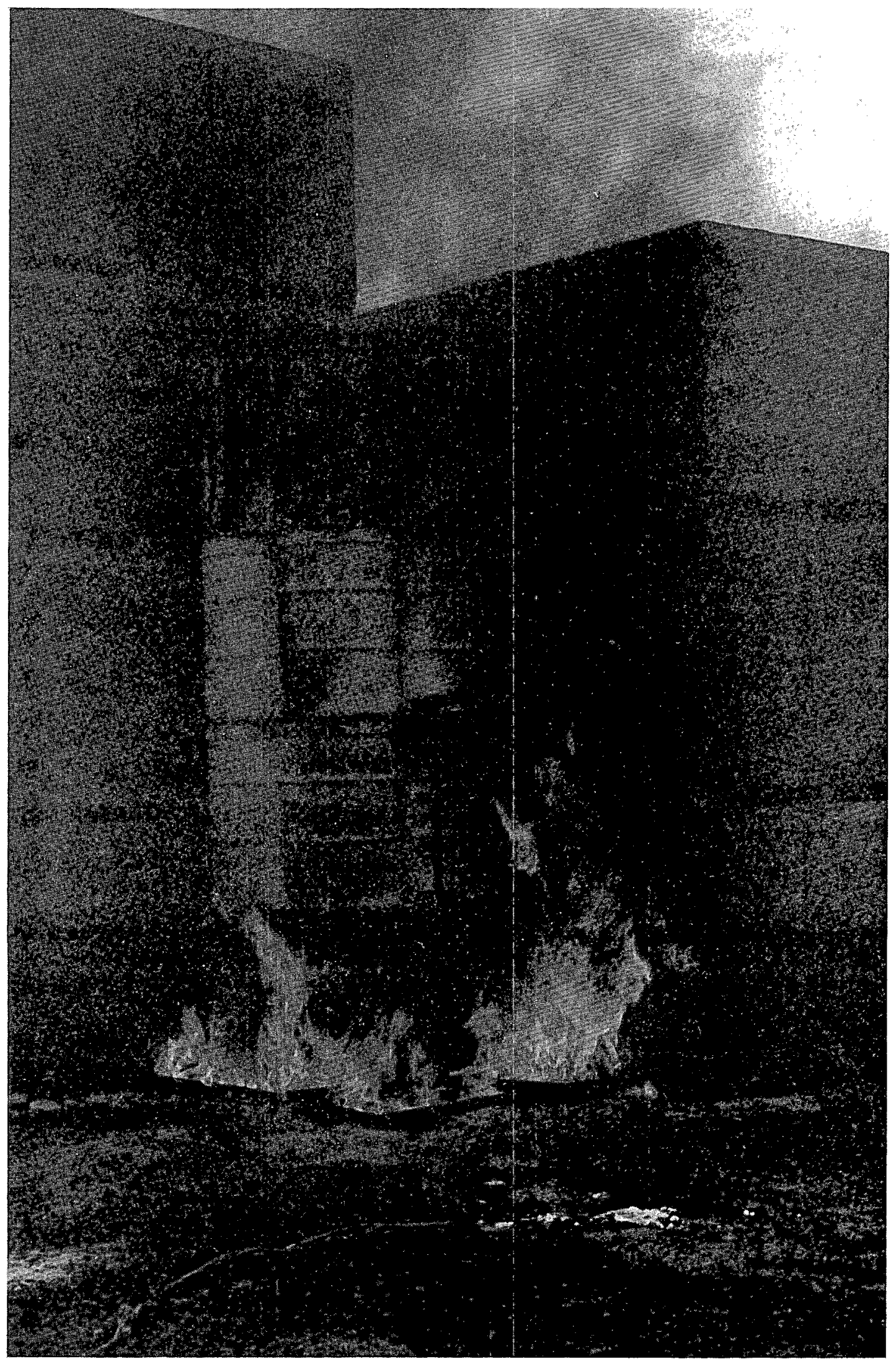

Fig. 17 Fire Test 2, time $3 \mathbf{~ m i n}$. 


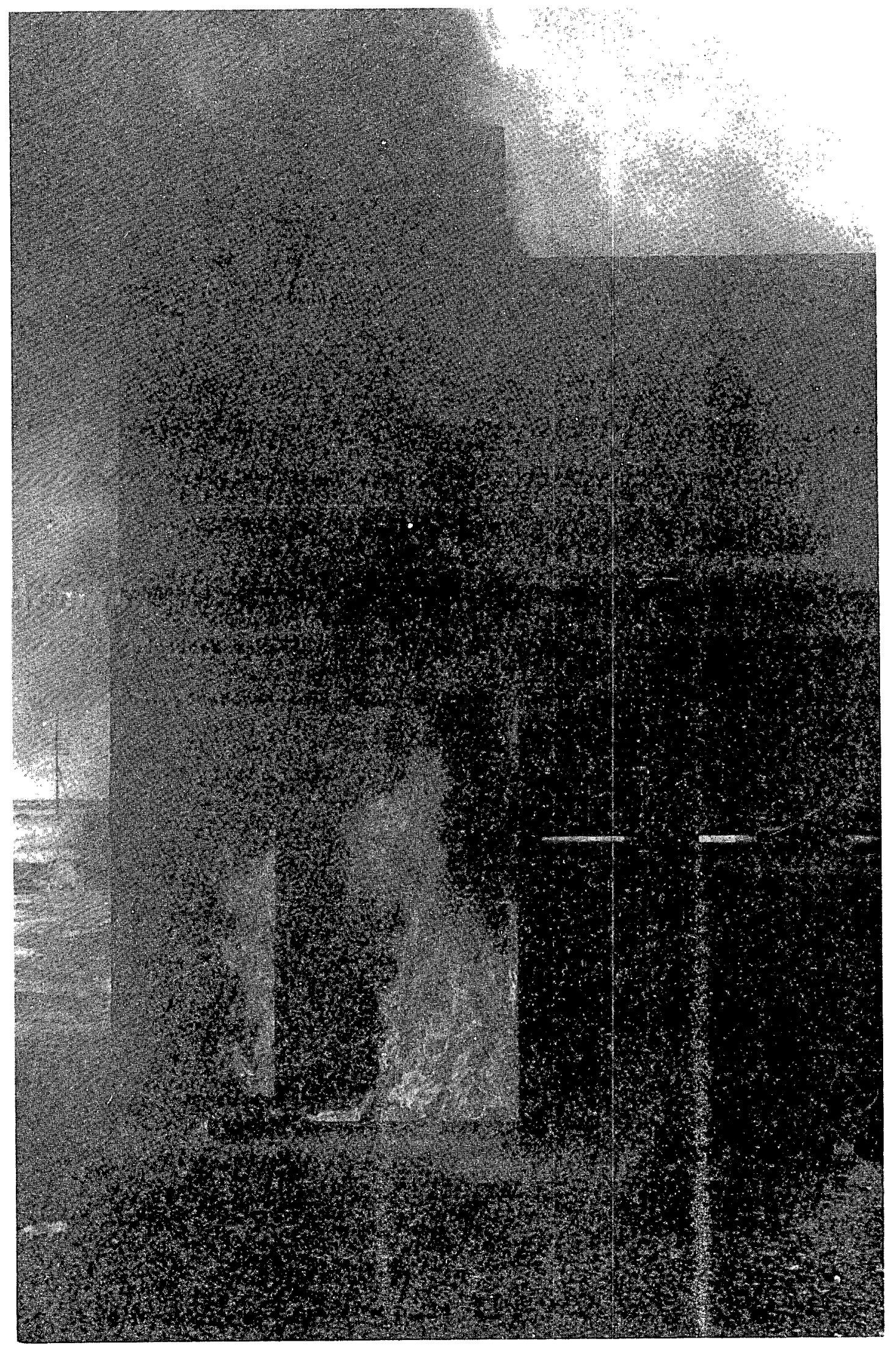

Fig. 18 Fire Test 2, time $7 \mathrm{~min}$. 


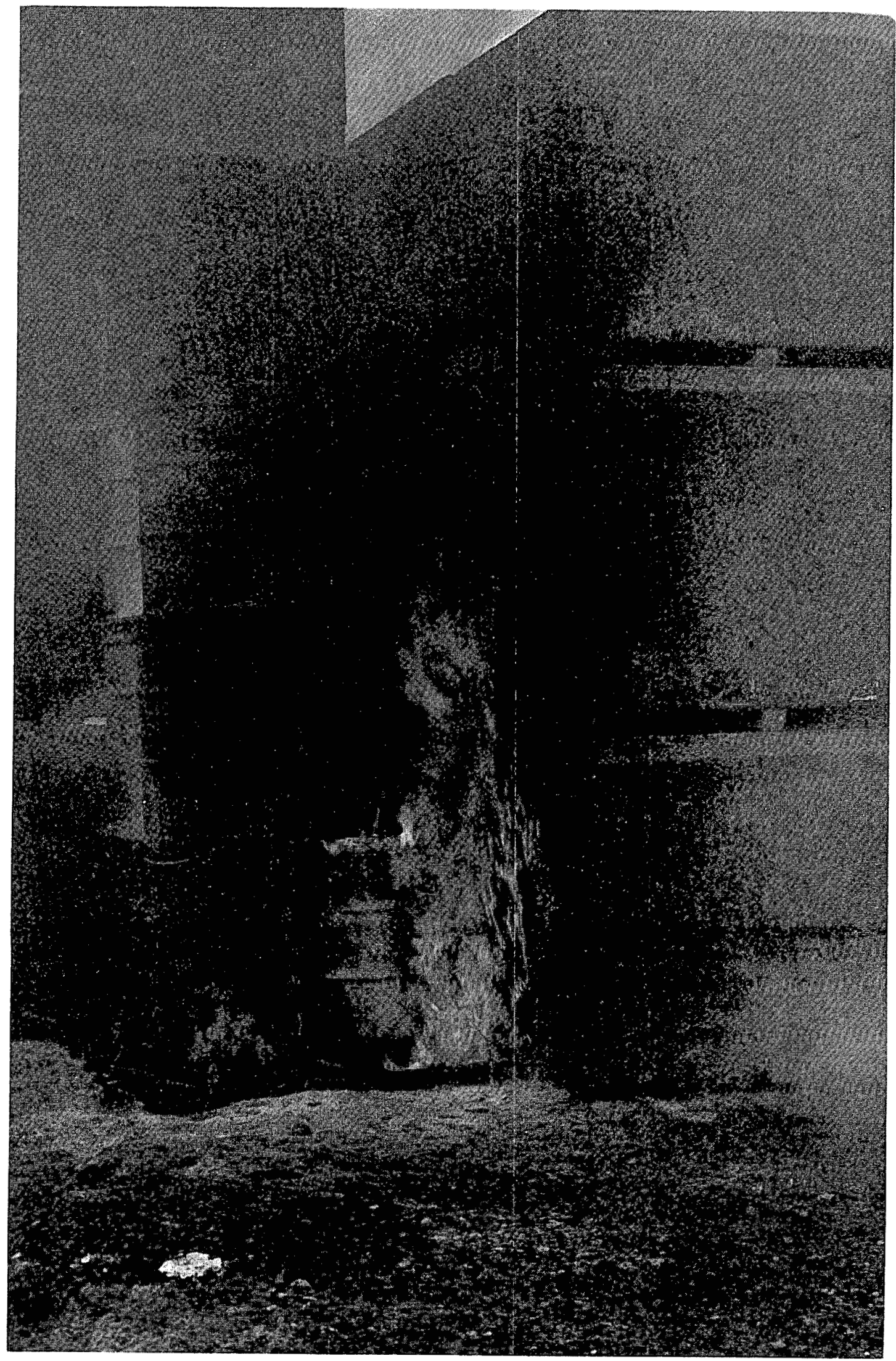

Fig. 19 Fire Test 2, time $12 \mathrm{~min}$. 


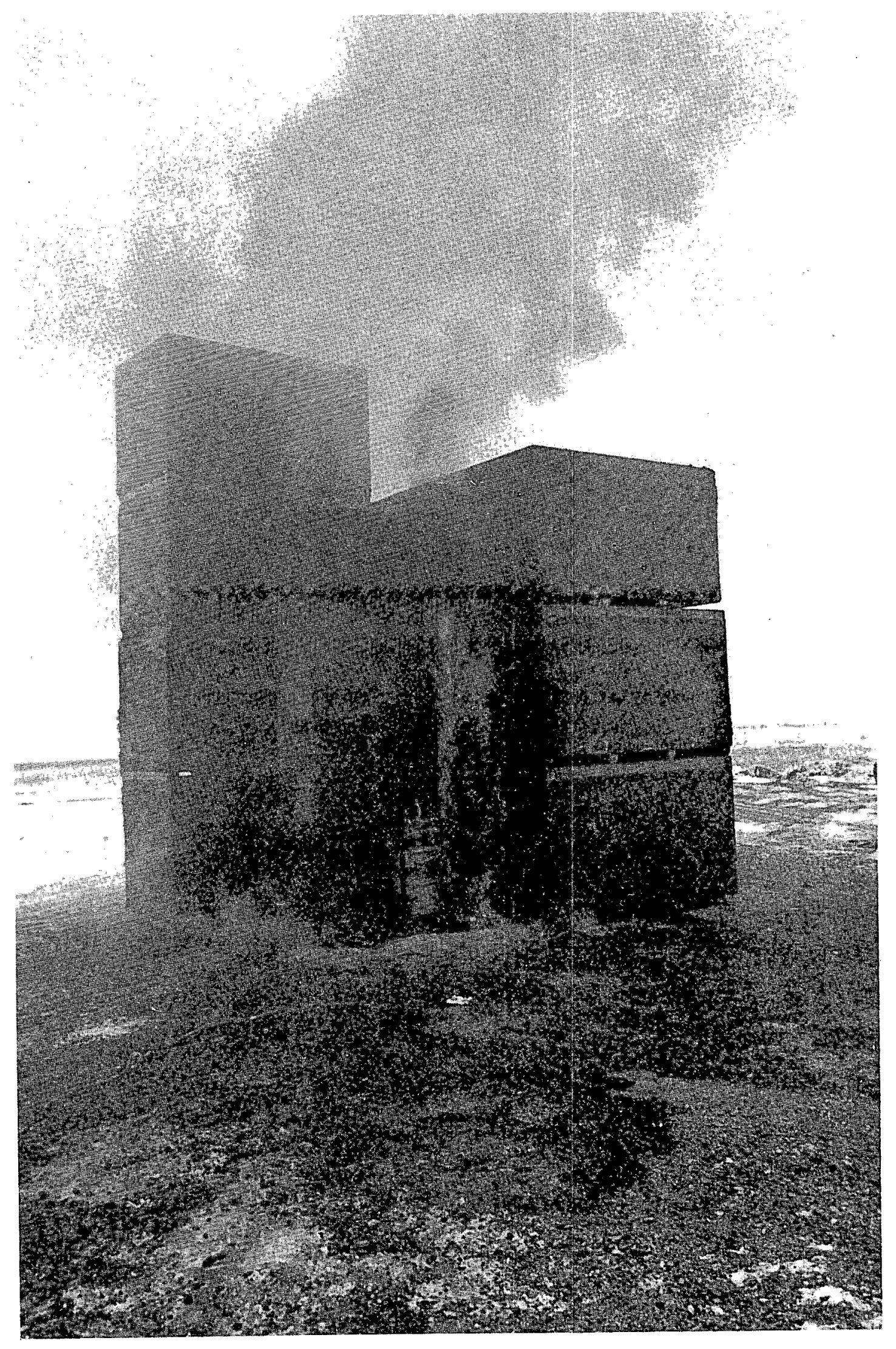

Fig. 20 Fire Test 2, time $20 \mathrm{~min}$. 


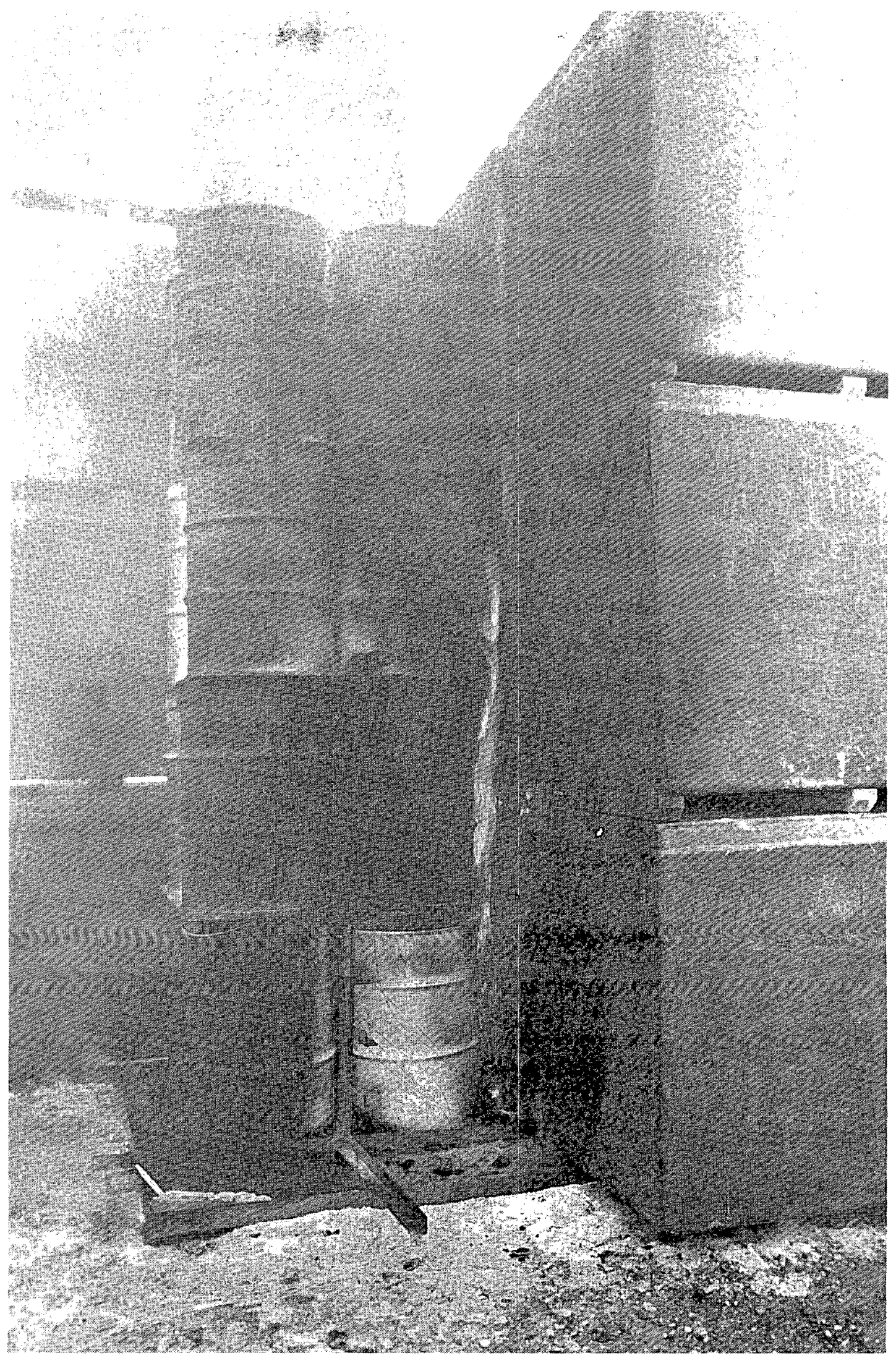

Fig. 21 Fire Test 2, time $31 \mathrm{~min}$. 


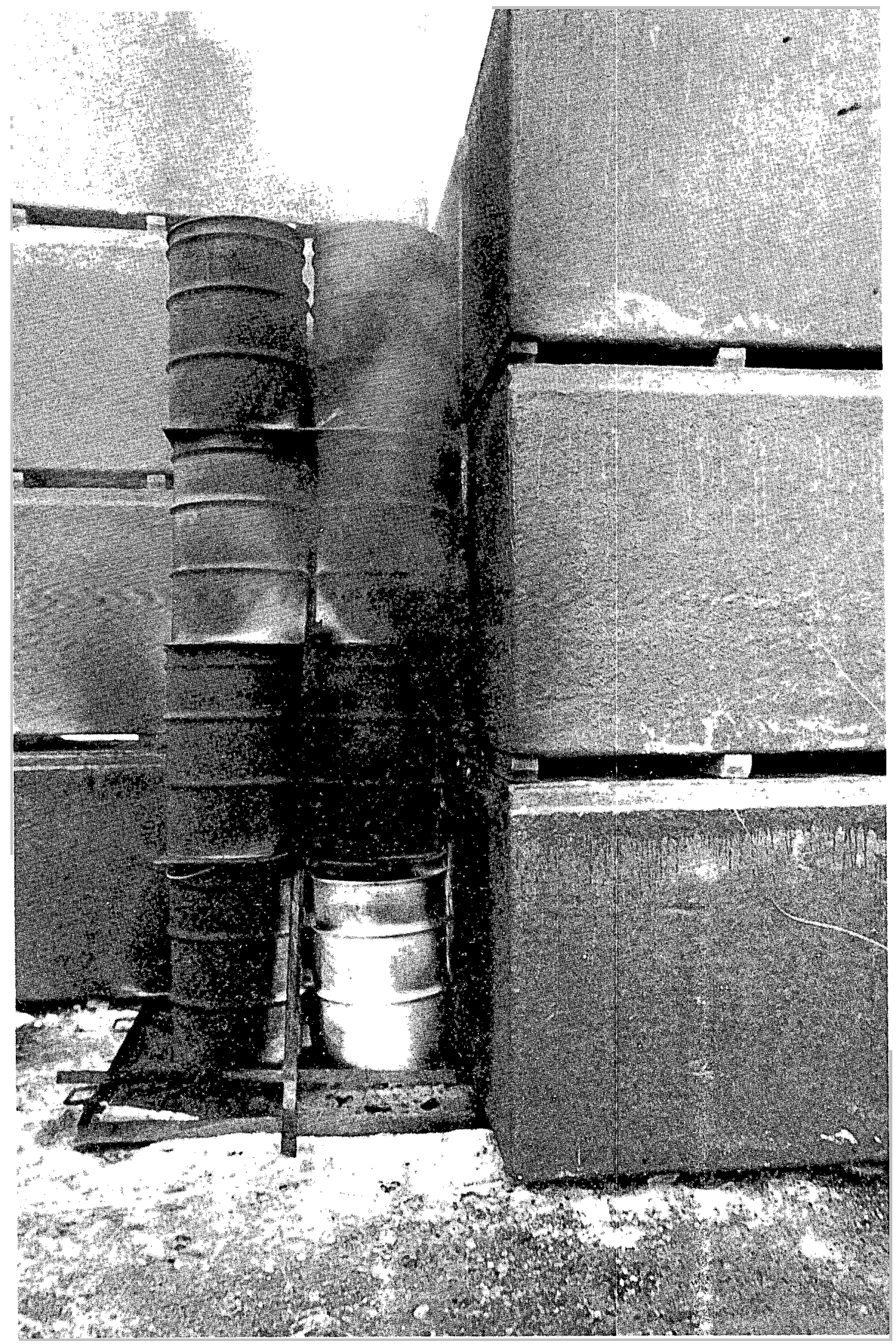

Fig. 22 Fire Test 2, time $40 \mathrm{~min}$. 


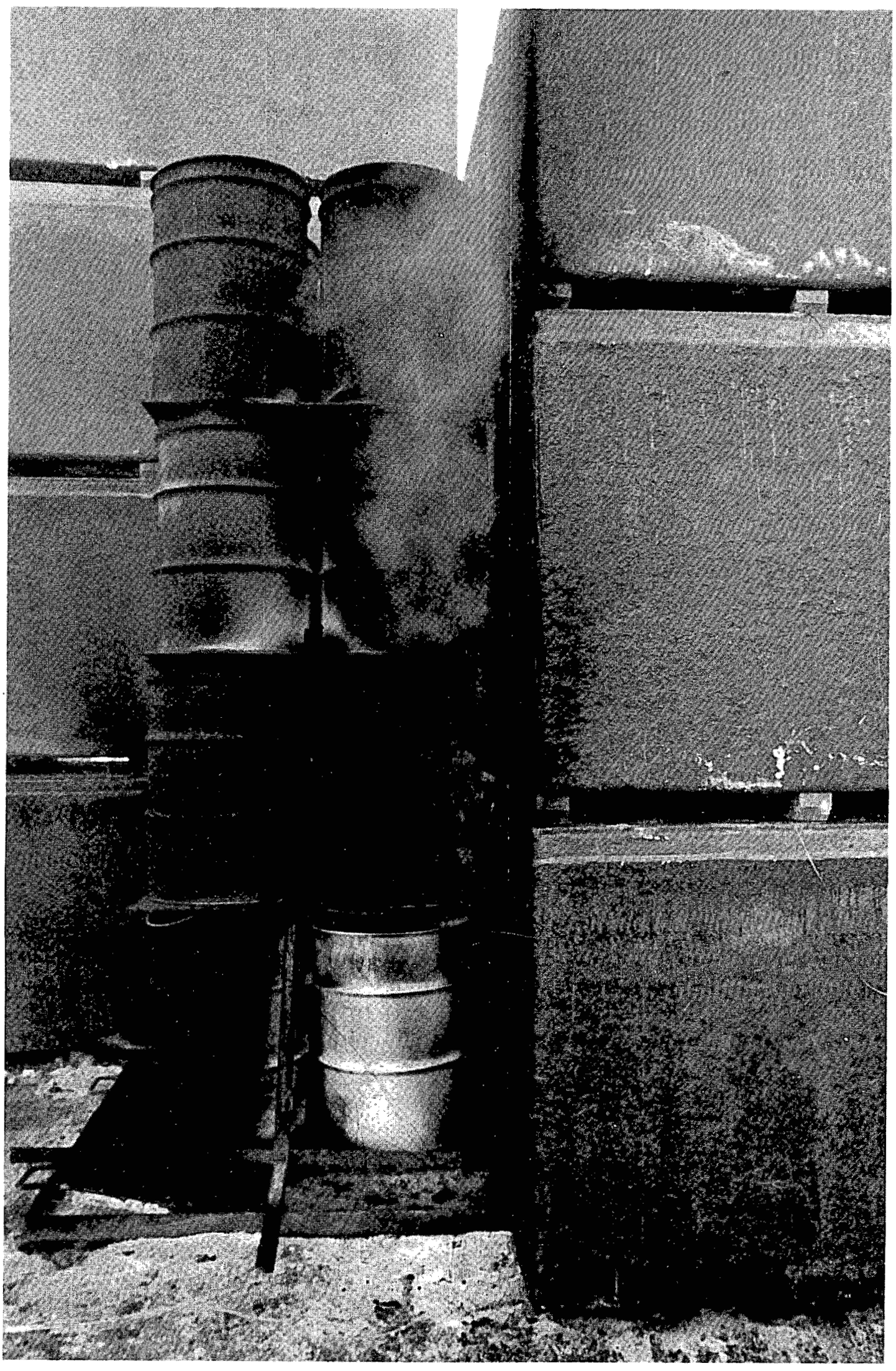

Fig. 23 Fire Test 2, time $50 \mathrm{~min}$. 


\section{FIRE TEST RESULTS}

Since TC (thermocouple) data collected during both fire tests were recorded and graphed in fahrenheit, this report will present this data accordingly rather than convert it to celsius. The TC data collected for each test were analyzed to separate insignificant temperature data from the significant data. However, for persons interested in raw data, all TC data obtained during both tests are contained on file at the EG\&G Waste Management Program-Operations office, and can be obtained upon request.

\section{FIRE TEST 1}

The source used for this test was a salt pad saturated with 56.81 (15 gal) of $\# 2$ diesel fuel. Table V, Fire Test 1 TC Data Summation, was used to determine the significant TC data obtained during the test. Significant TC data is data whose maximum temperature is greater than $250^{\circ} \mathrm{F}$ or data from TCs located in areas deemed significant for comparison purposes and/or flue effects. Using this criteria and Table V, Table VI presents TCs which are considered significant temperature data for Fire Test 1. Figures 24 to 48 show TC temperature data for Fire Test 1.

TABLE V

FIRE TEST 1, TC DATA SUMMATION

\begin{tabular}{|c|c|c|c|}
\hline \multicolumn{4}{|c|}{ Unit of Measure $\left({ }^{\circ} F\right)$} \\
\hline $\begin{array}{l}\text { Channel } \\
\text { Number }\end{array}$ & $\begin{array}{c}\text { Number of } \\
\text { Samples } \\
\end{array}$ & $\begin{array}{l}\text { Minimum } \\
\text { Value }\end{array}$ & $\begin{array}{l}\text { Maximum } \\
\text { Value } \\
\end{array}$ \\
\hline$A-0$ & 85 & 28.7 & 1377.6 \\
\hline$A-1$ & 84 & 19.6 & 75.5 \\
\hline$A-2$ & 84 & 19.9 & 69.4 \\
\hline$A-3$ & 84 & 39.8 & 68.0 \\
\hline A- 4 & 84 & 48.4 & 523.5 \\
\hline$A-5$ & 85 & 19.1 & 121.3 \\
\hline$A-6$ & 85 & 14.9 & 51.7 \\
\hline$A-7$ & 85 & 49.6 & 73.3 \\
\hline$A-8$ & 85 & 51.1 & 238.3 \\
\hline$A-9$ & 85 & 23.3 & 47.0 \\
\hline$A-10$ & 85 & 19.5 & 38.1 \\
\hline$A-11$ & 85 & 49.7 & 57.9 \\
\hline$A-12$ & 85 & 60.8 & 137.8 \\
\hline$A-13$ & 85 & 58.5 & 60.4 \\
\hline$A-14$ & 85 & 24.5 & 621.2 \\
\hline$A-15$ & 85 & 40.6 & 1165.7 \\
\hline$A-16$ & 85 & 34.7 & 36.8 \\
\hline$A-17$ & 85 & 26.3 & 31.6 \\
\hline
\end{tabular}


TABLE V (continued)

Unit of Measure (OF)

\begin{tabular}{|c|c|c|c|}
\hline $\begin{array}{l}\text { Channe1 } \\
\text { Number }\end{array}$ & $\begin{array}{c}\text { Number of } \\
\text { Samples } \\
\end{array}$ & $\begin{array}{l}\text { Minimum } \\
\text { Value }\end{array}$ & $\begin{array}{l}\text { Maximum } \\
\text { Value } \\
\end{array}$ \\
\hline$A-18$ & 85 & 26.2 & 53.9 \\
\hline$A-19$ & 85 & 29.6 & 31.2 \\
\hline$A-20$ & 85 & 20.2 & 22.8 \\
\hline$A-21$ & 85 & 20.7 & 34.1 \\
\hline$A-22$ & 86 & 22.2 & 27.4 \\
\hline$A-23$ & 85 & 20.5 & 23.8 \\
\hline$A-24$ & 86 & 21.7 & 27.1 \\
\hline$A-25$ & 85 & 34.4 & 47.8 \\
\hline$A-26$ & 85 & 51.3 & 579.6 \\
\hline$A-27$ & 85 & 36.6 & 52.3 \\
\hline$A-28$ & 85 & 45.1 & 615.6 \\
\hline$A-29$ & 86 & 29.2 & 61.5 \\
\hline$A-30$ & 85 & 23.3 & 1277.2 \\
\hline$A-31$ & 85 & ---- & 0.0 \\
\hline$A-32$ & 85 & 26.7 & 43.8 \\
\hline$A-33$ & 85 & 56.9 & 61.7 \\
\hline$A-34$ & 85 & 28.9 & 51.5 \\
\hline$A-35$ & 85 & 46.7 & 129.2 \\
\hline$A-36$ & 85 & 23.6 & 27.2 \\
\hline$A-37$ & 85 & 53.9 & 60.1 \\
\hline$A-38$ & 85 & 23.8 & 56.9 \\
\hline$A-39$ & 85 & 39.7 & 126.2 \\
\hline$A-40$ & 85 & 22.1 & 39.5 \\
\hline$A-41$ & 86 & 40.7 & 63.6 \\
\hline$A-42$ & 85 & 22.9 & 34.8 \\
\hline$A-43$ & 85 & 42.8 & 78.8 \\
\hline A-44 & 85 & ---- & 0.0 \\
\hline$A-45$ & 85 & $-\cdots$ & 0.0 \\
\hline$A-46$ & 85 & ---- & 0.0 \\
\hline$A-47$ & 85 & --- & 0.0 \\
\hline$A-48$ & 85 & ---- & 0.0 \\
\hline
\end{tabular}


TABLE V (cont inued)

\begin{tabular}{|c|c|c|c|}
\hline \multicolumn{4}{|c|}{ Unit of Measure $\left({ }^{\circ} F\right)$} \\
\hline $\begin{array}{l}\text { Channe 1 } \\
\text { Number }\end{array}$ & $\begin{array}{c}\text { Number of } \\
\text { Samples } \\
\end{array}$ & $\begin{array}{l}\text { Minimum } \\
\text { Value }\end{array}$ & $\begin{array}{l}\text { Maximum } \\
\text { Value }\end{array}$ \\
\hline$A-49$ & 85 & ---- & 0.0 \\
\hline$A-50$ & 85 & 31.1 & 1081.9 \\
\hline$A-51$ & 85 & 33.3 & 806.4 \\
\hline$A-52$ & 85 & 31.8 & 551.8 \\
\hline$A-53$ & 85 & 31.0 & 466.8 \\
\hline$A-54$ & 85 & 34.1 & 351.3 \\
\hline$A-55$ & 86 & 30.7 & 216.2 \\
\hline$A-56$ & 85 & ---- & 69.4 \\
\hline$A-57$ & 85 & --- & 0.0 \\
\hline$A-58$ & 85 & ---- & 0.0 \\
\hline
\end{tabular}

TABLE VI

SIGNIFICANT TEMPERATURE DATA FOR FIRE TEST 1

Channe1 Number

0

1

3

4

5

7

11

14

22

24

15

19

21

30
Location

Box Al side face

Box Al/B1 flue

Box A, inside

Box A2 side face

Box A2/B2 flue

Box A2 inside

Box A3 inside

Box $B 1$ end face

Box $B 1$ inside

Box $B 1 / C 1$ flue

Box B2 end face

Box B2 inside

Box B2/C 2 flue

Box $\mathrm{Cl}$ end face

\section{Figure}

24

25

26

27

28

29

30

31

32

33

34

35

36

37 
TABLE VI (continued)

\begin{tabular}{cllc}
\hline Channe1 Number & \multicolumn{1}{c}{ Location } & Figure \\
\cline { 2 - 3 } 29 & Box C1 inside & 38 \\
42 & Box C1/D1 f1ue & 39 \\
28 & Box C2 end face & 40 \\
27 & Box C2 inside & 41 \\
38 & Box C2/D2 f1ue & 42 \\
26 & Box C3 end face & 43 \\
25 & Box C3 inside & 44 \\
34 & Box C3/D3 f1ue & 45 \\
50 & TC Tree & 46 \\
52 & TC Tree & 47 \\
54 & TC Tree & 48 \\
\hline
\end{tabular}

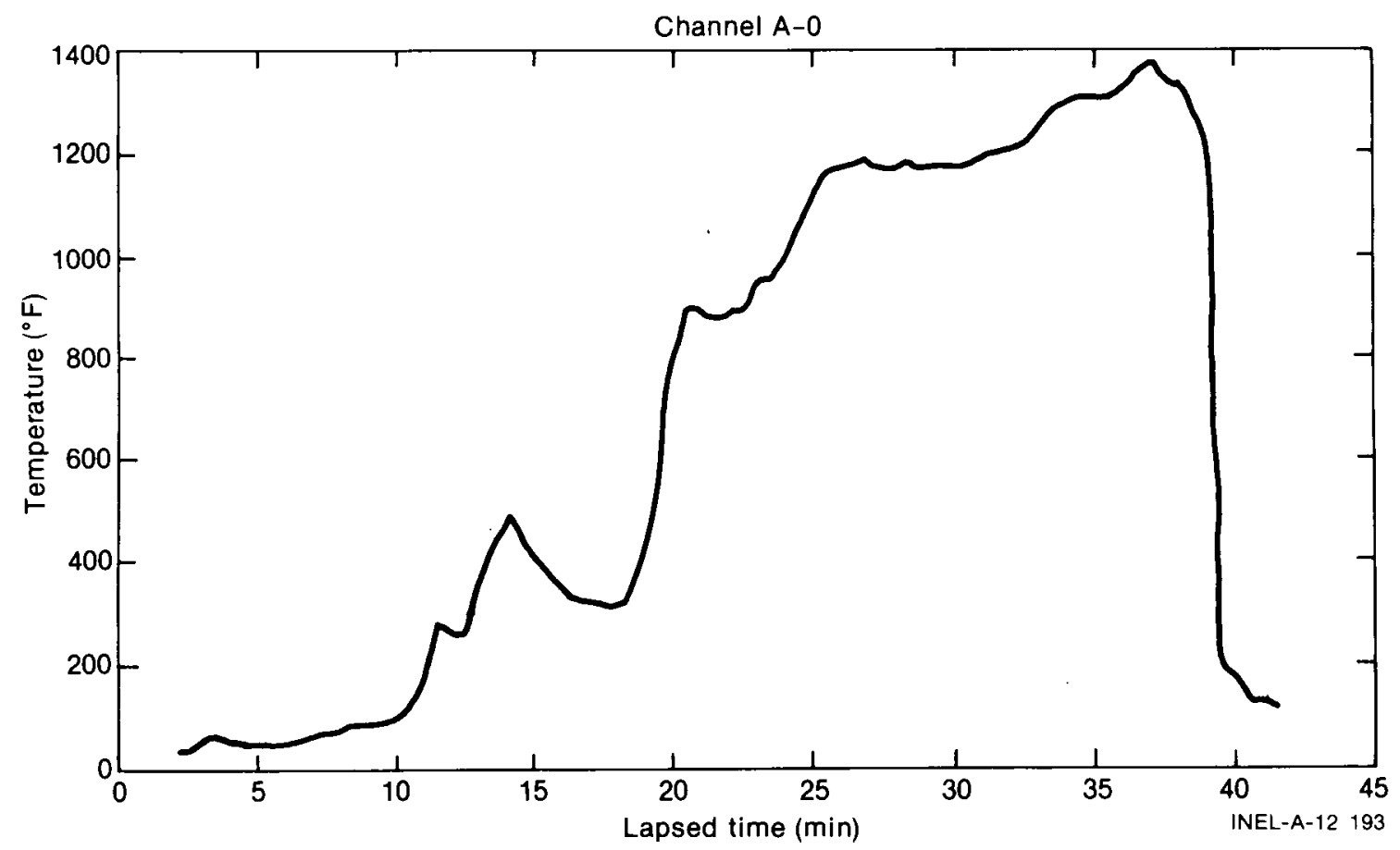

Fig. 24 Box A1 side face. 


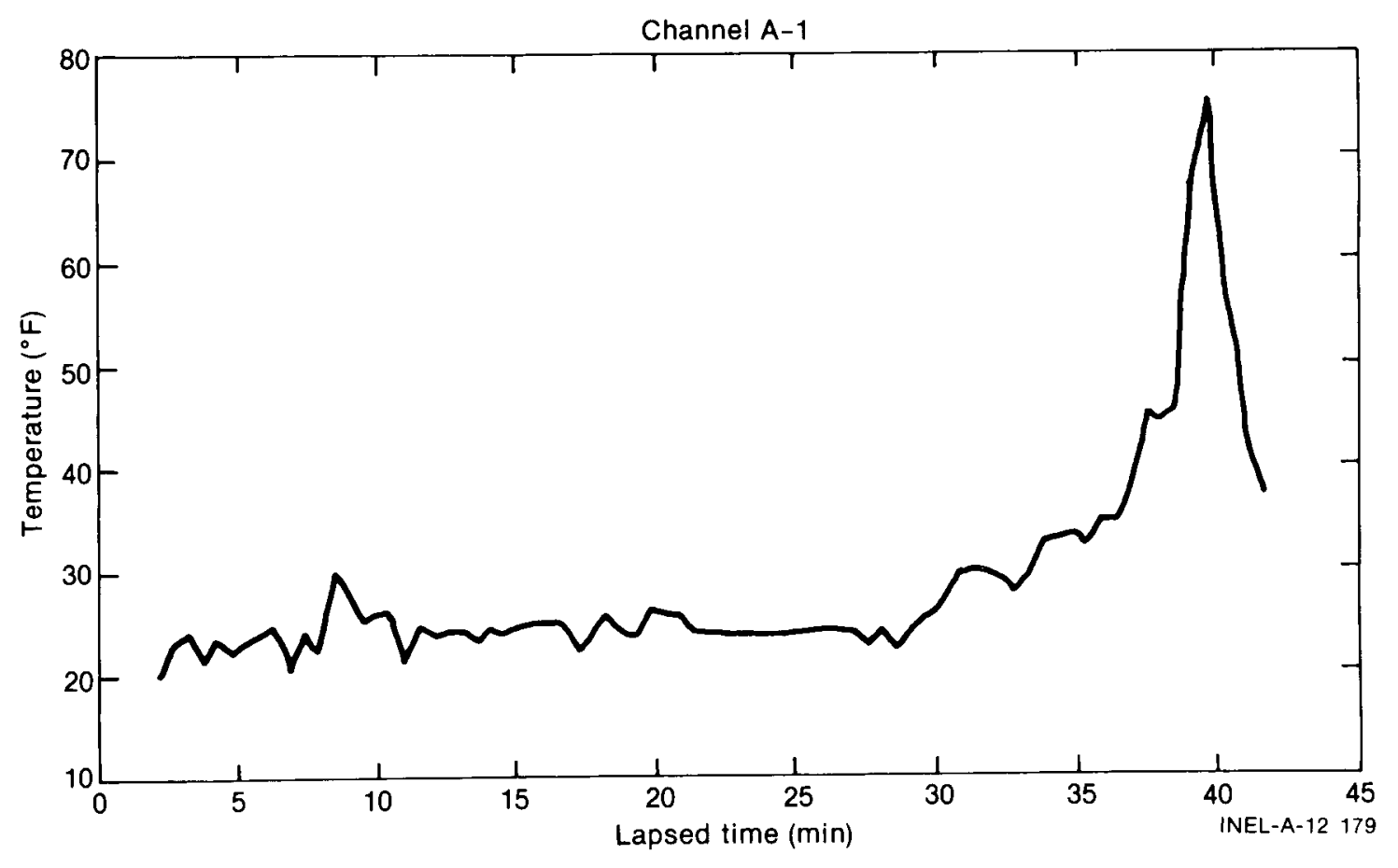

Fig. 25 Box A1/B1 flue.

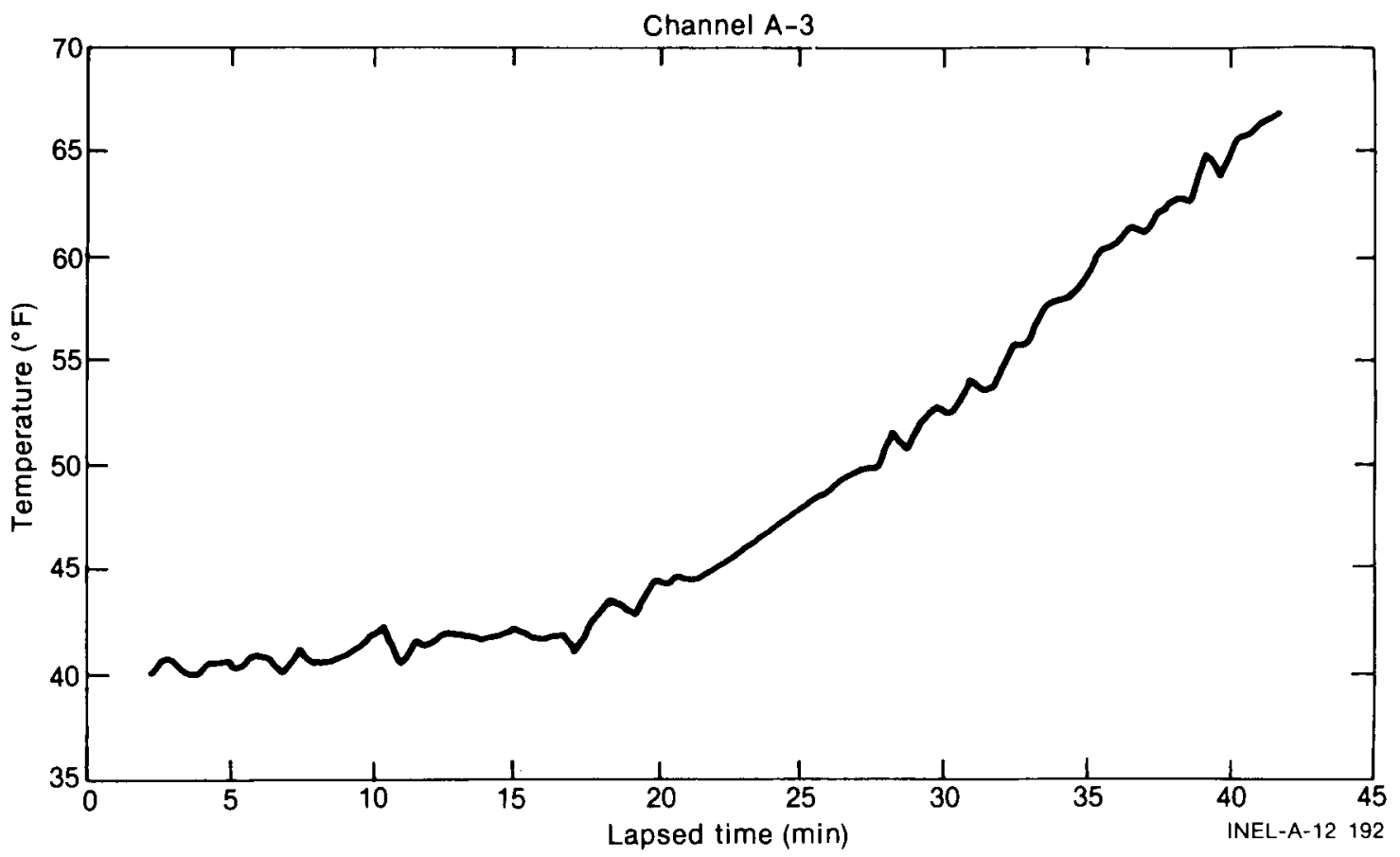

Fig. 26 Box A1 inside. 


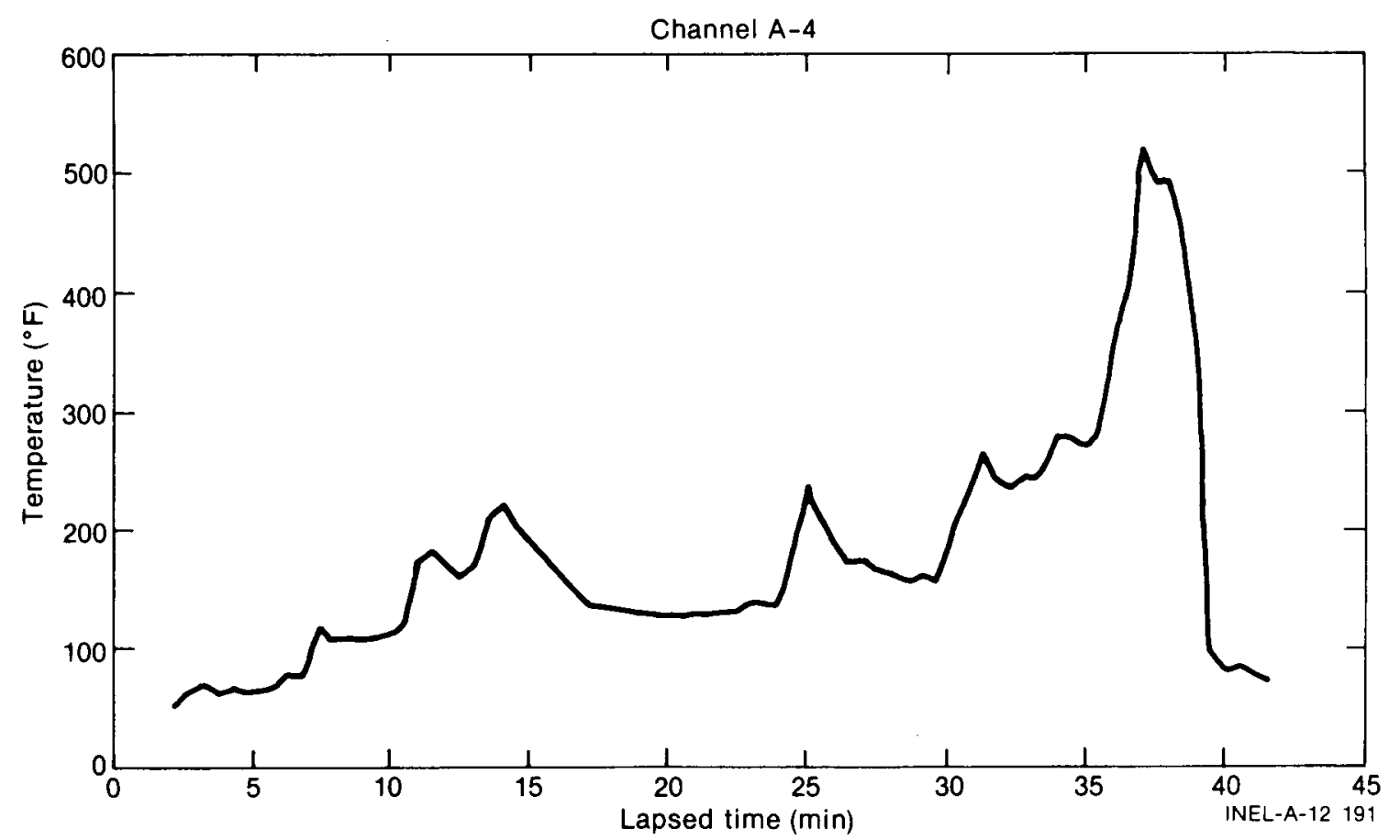

Fig. 27 Box A2 side face.

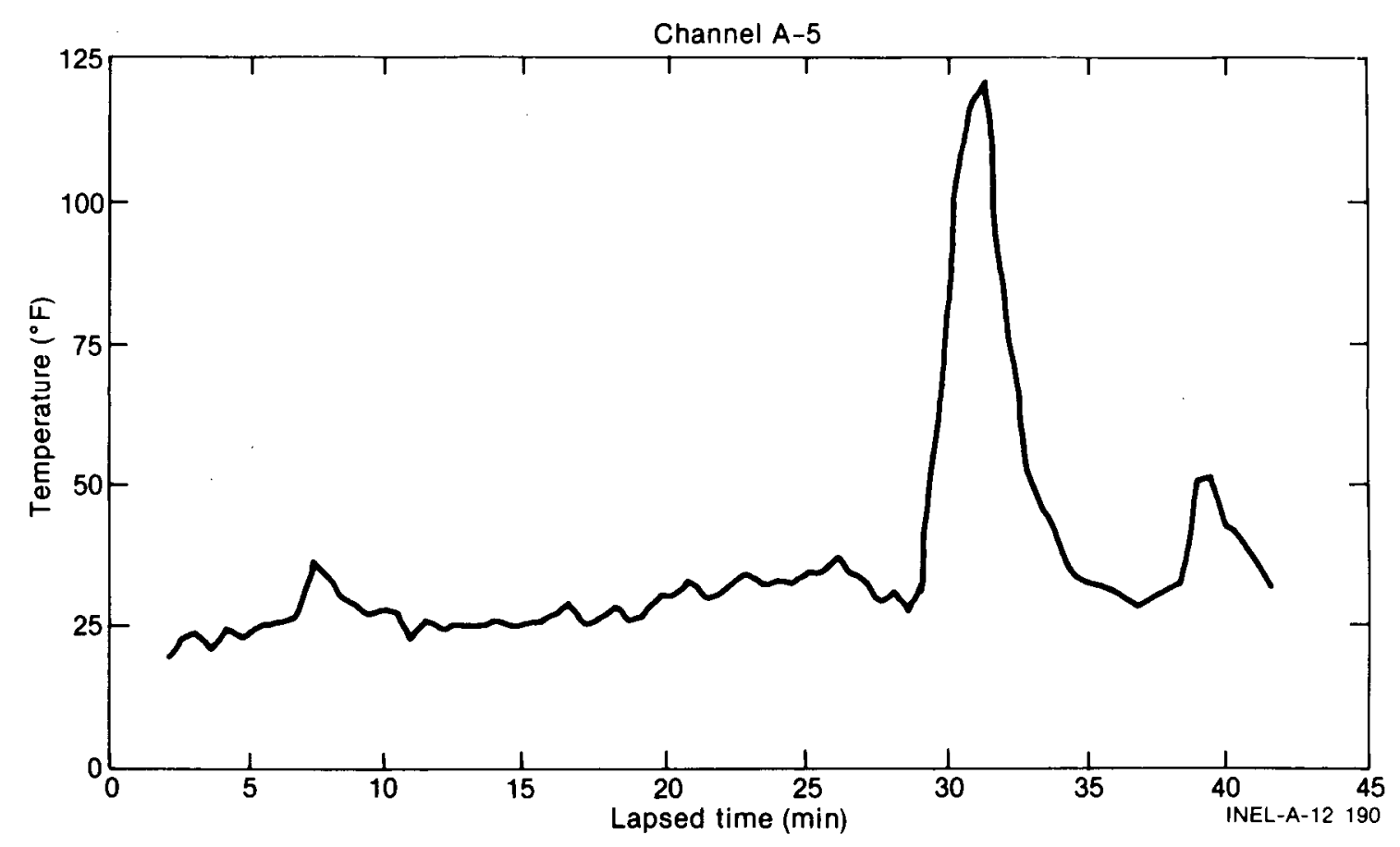

Fig. 28 Box A2/B2 flue. 


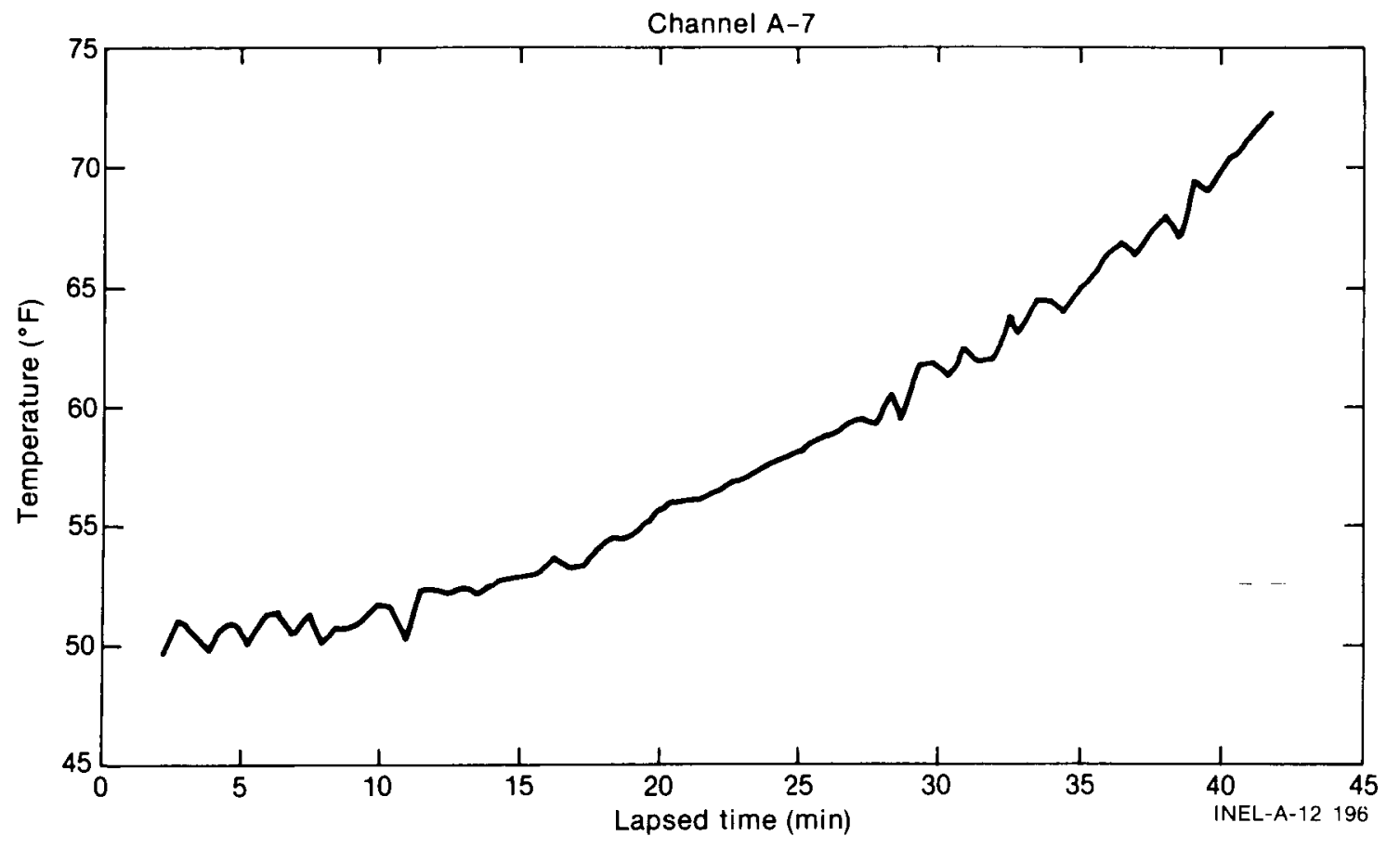

Fig. 29 Box A2 inside.

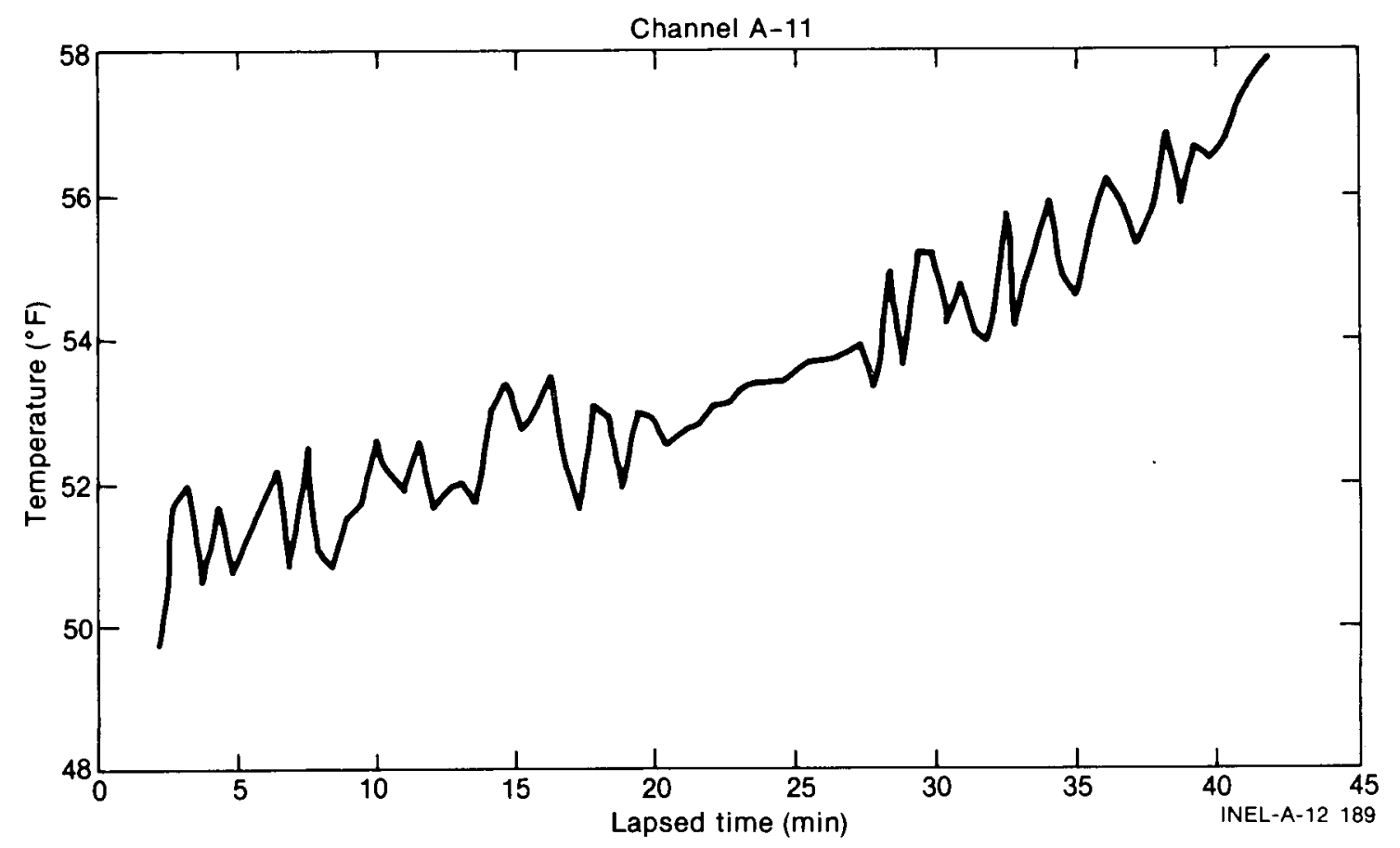

Fig. 30 Box A3 inside. 


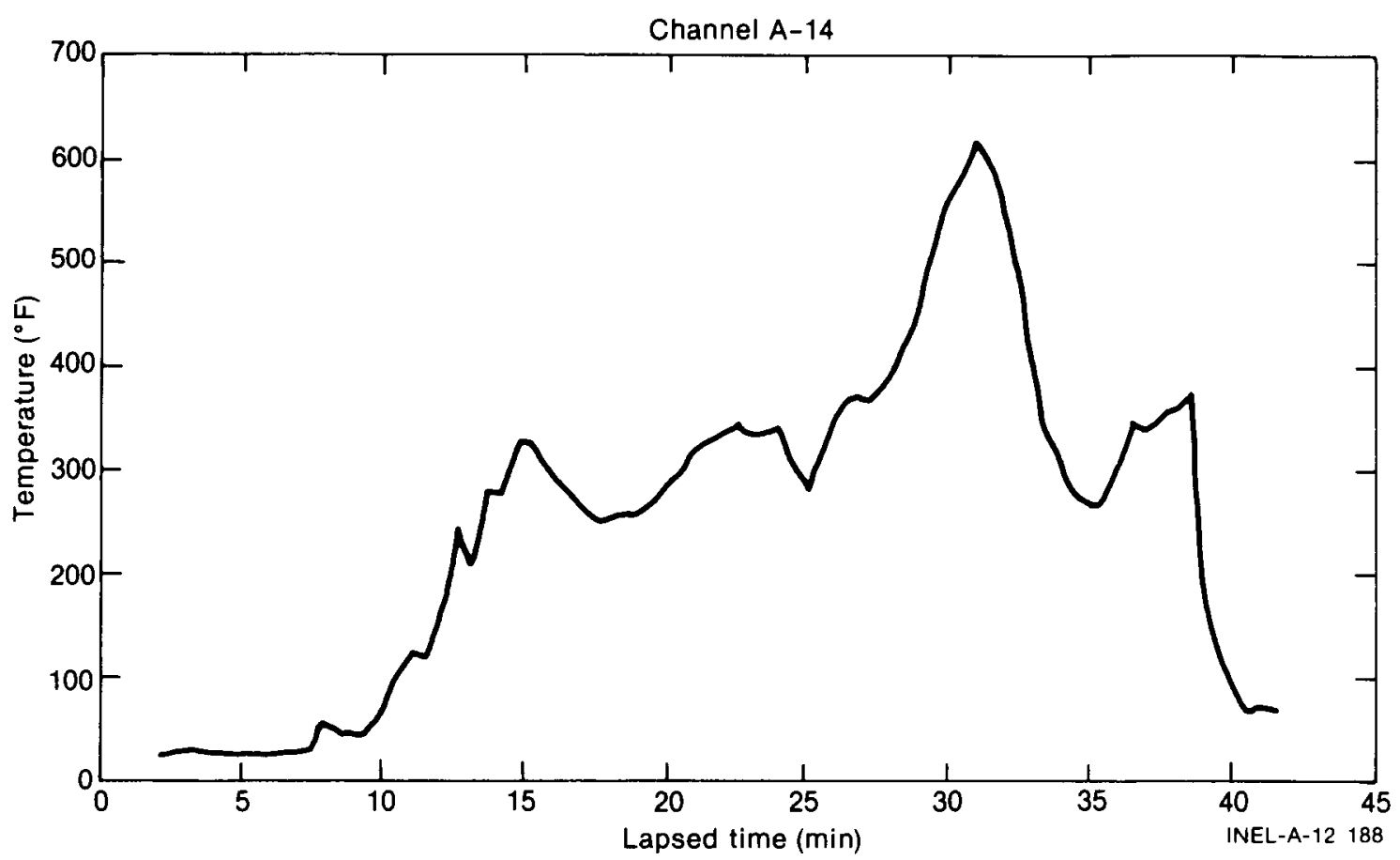

Fig. 31 Box B2 end corner.

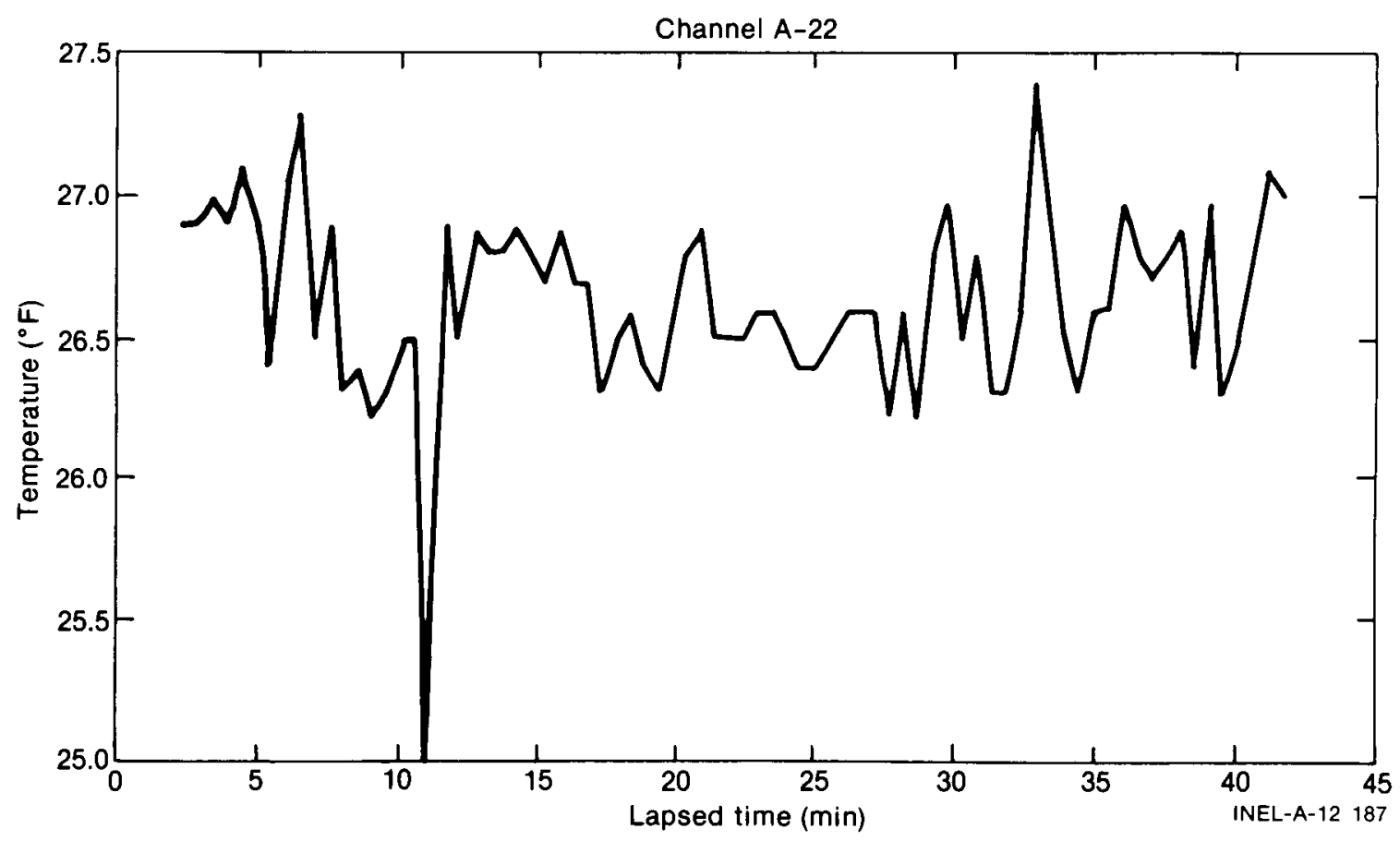

Fig. 32 Box B1 inside. 


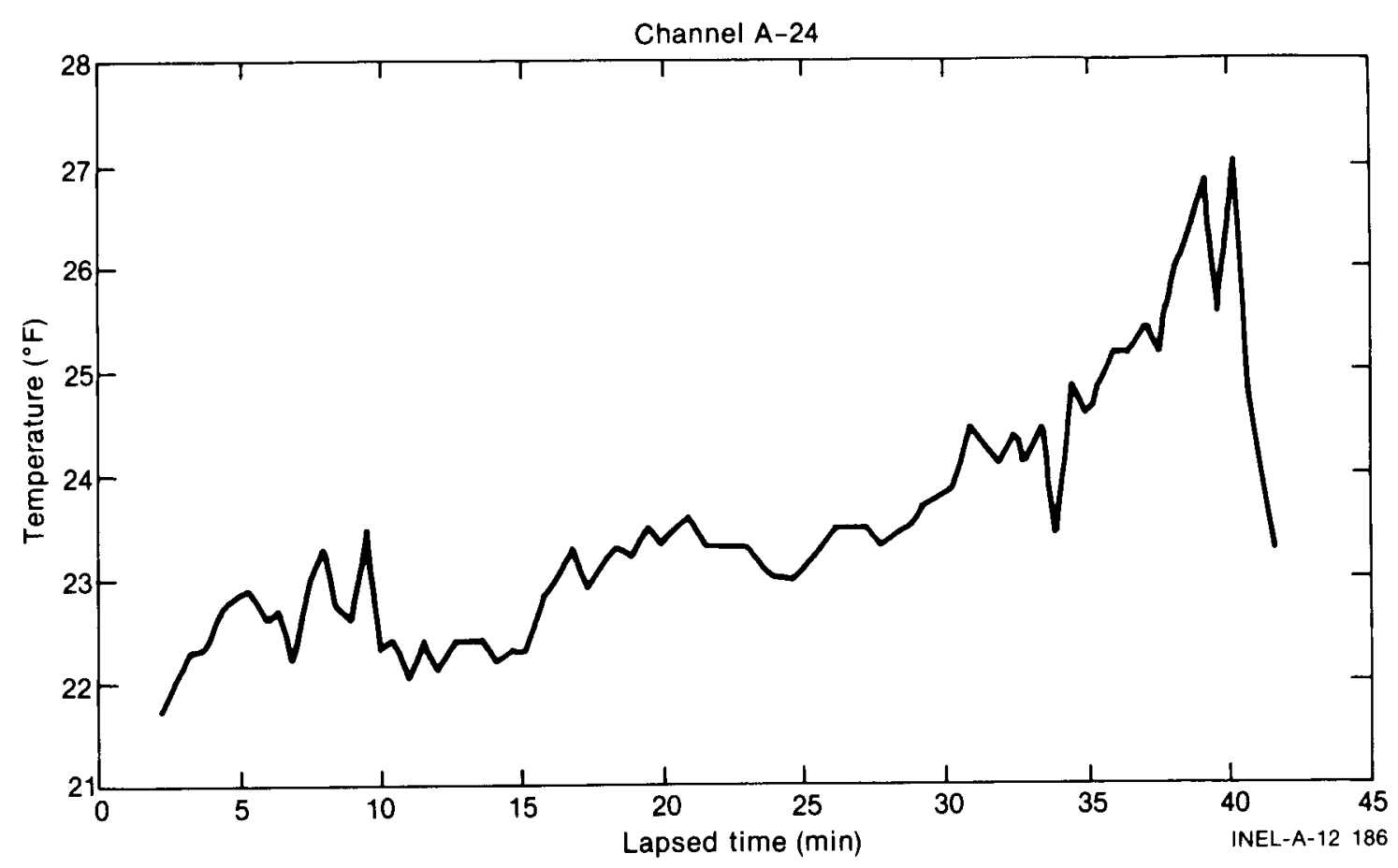

Fig. 33 Box B1/C1 flue.

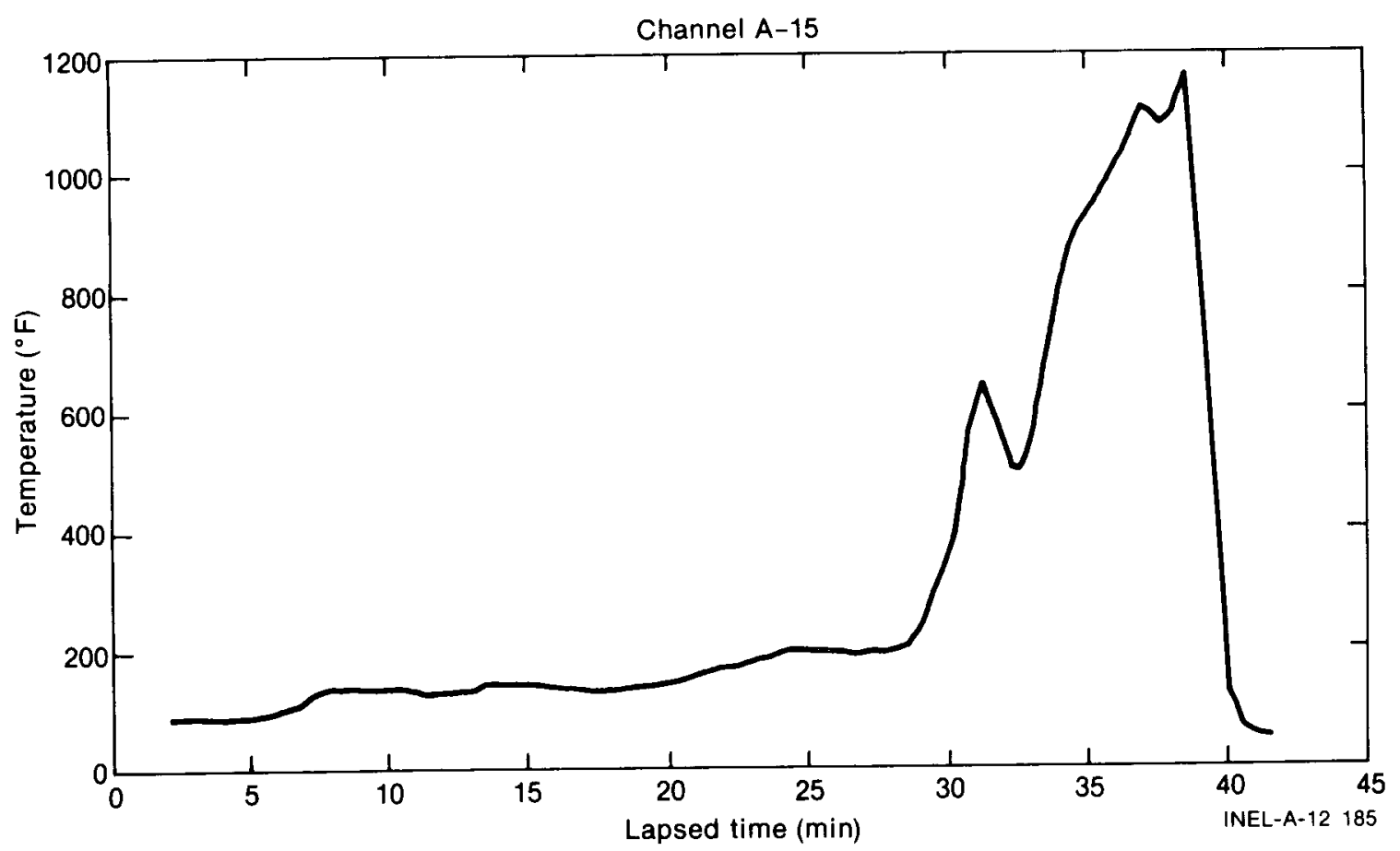

Fig. 34 Box B3 end corner. 


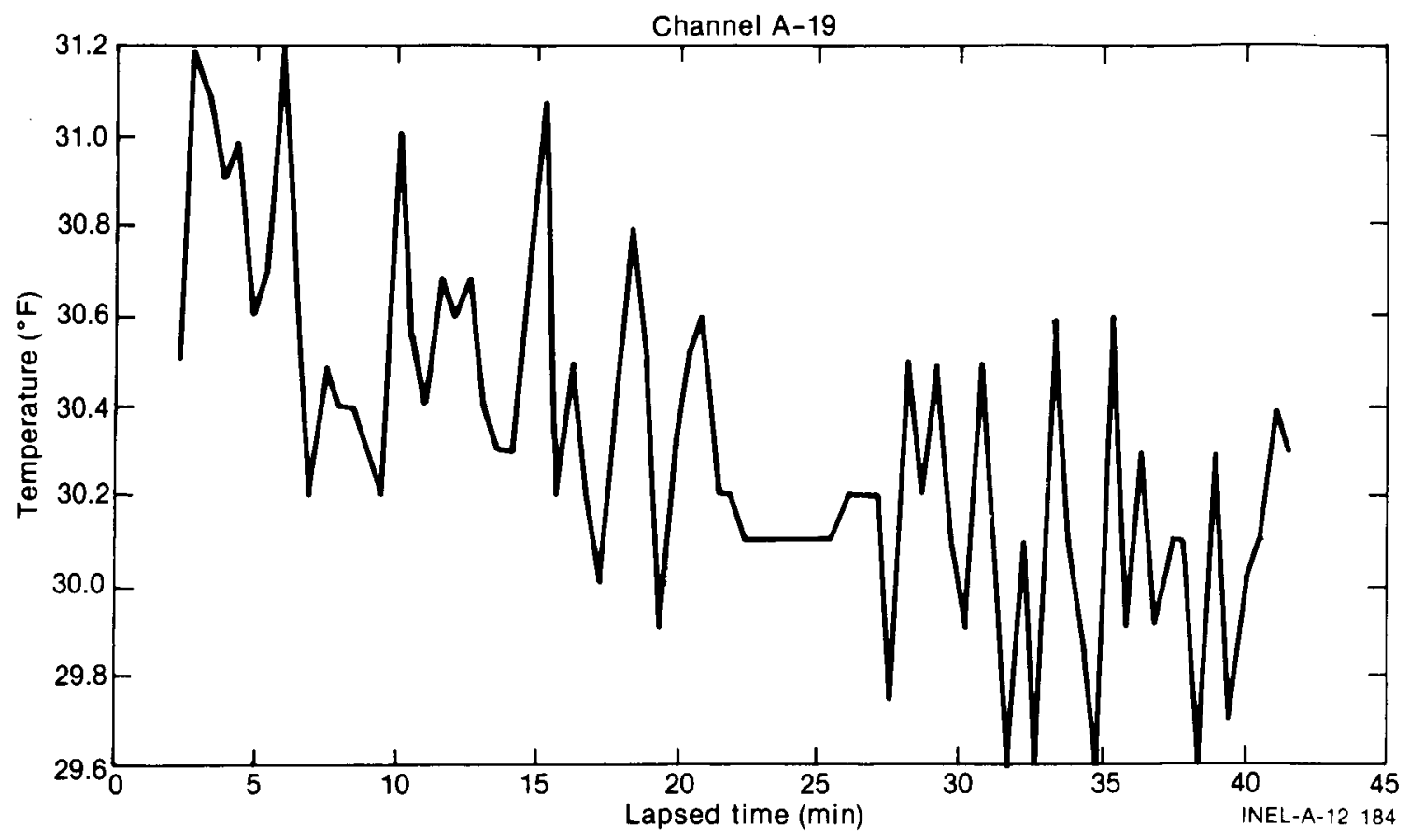

Fig. 35 Box B2 inside.

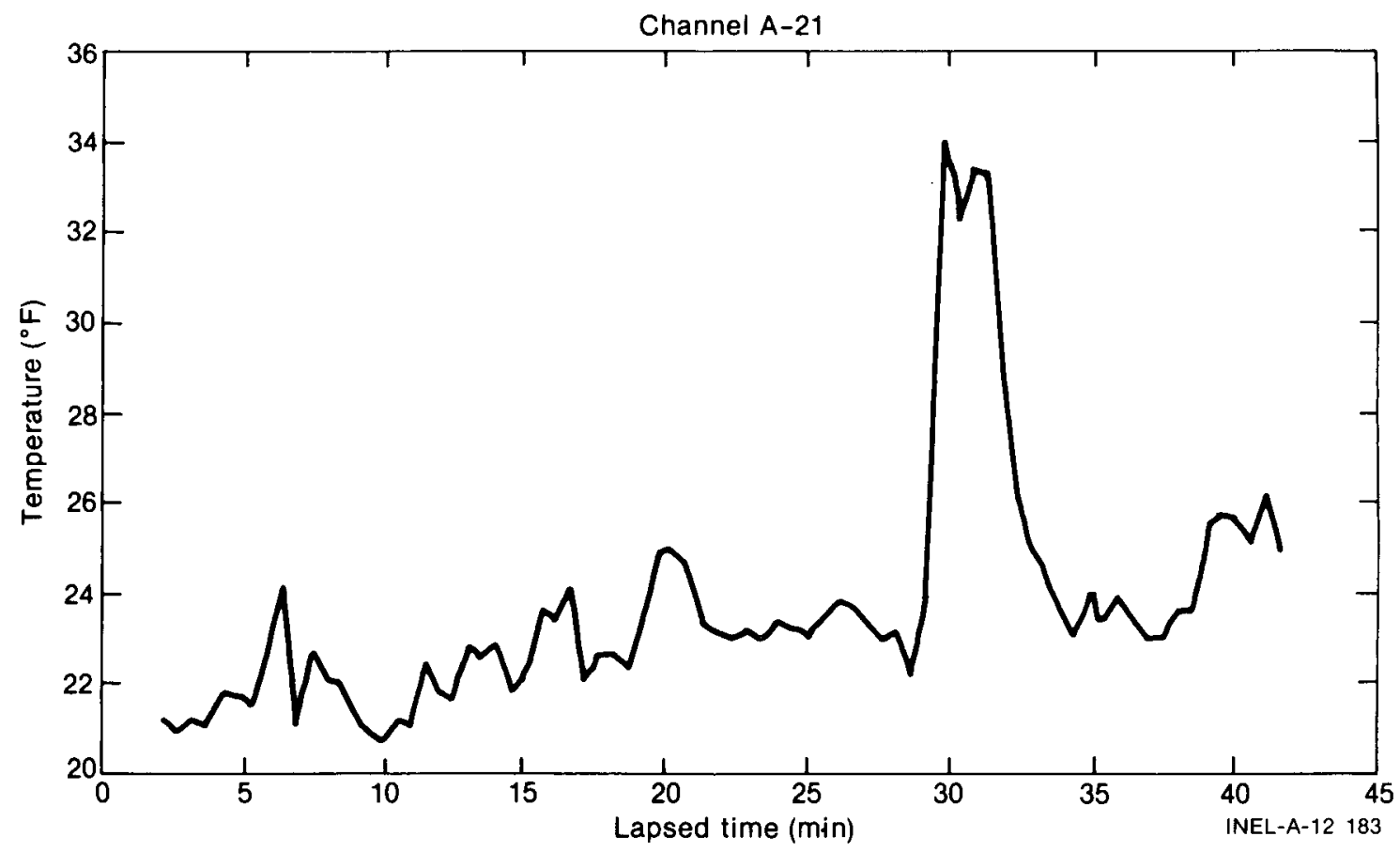

Fig. 36 Box B2/C2 flue. 


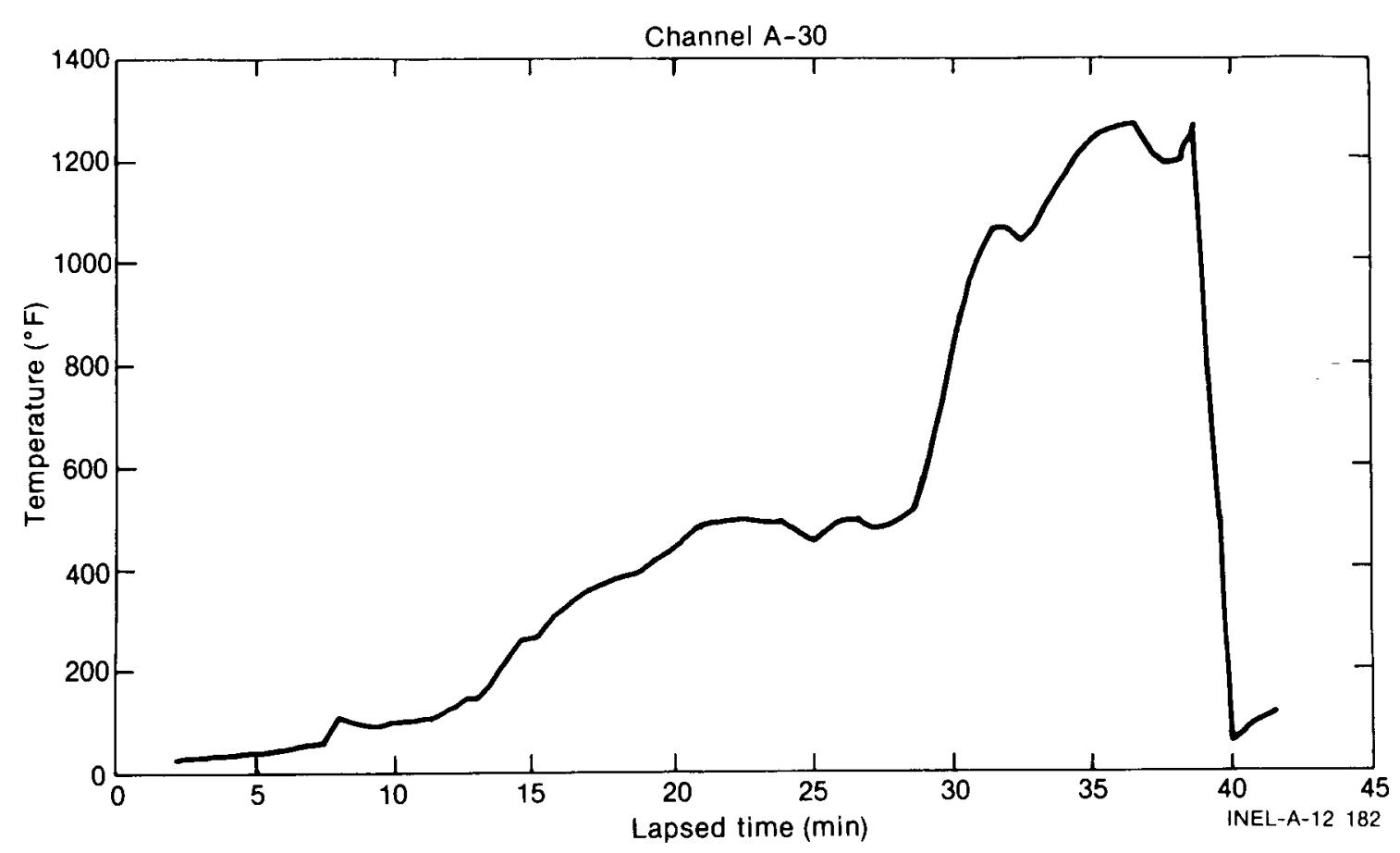

Fig. 37 Box C1 end face.

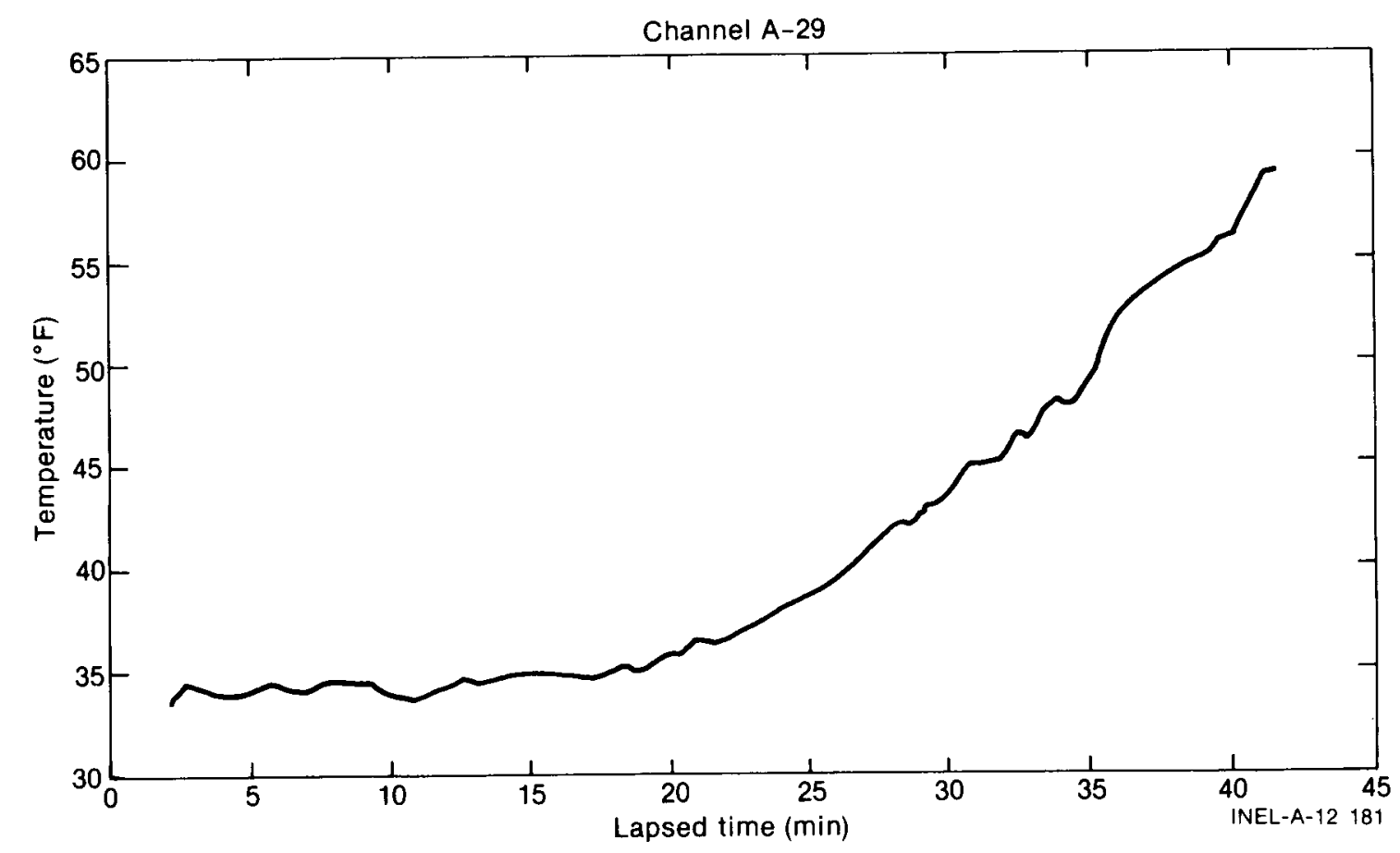

Fig. 38 Box C1 inside. 


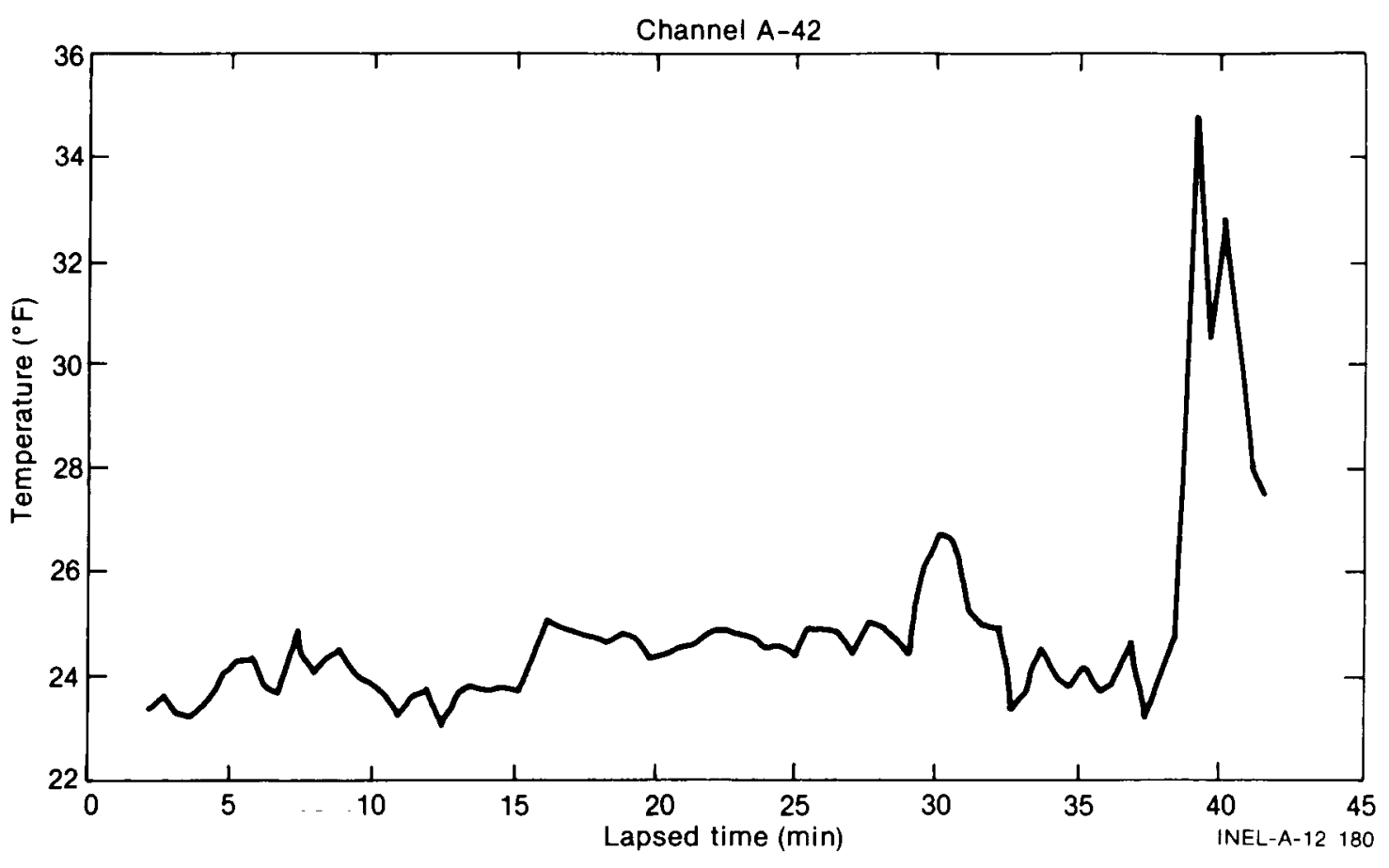

Fig. 39 Box C1/D1 flue.

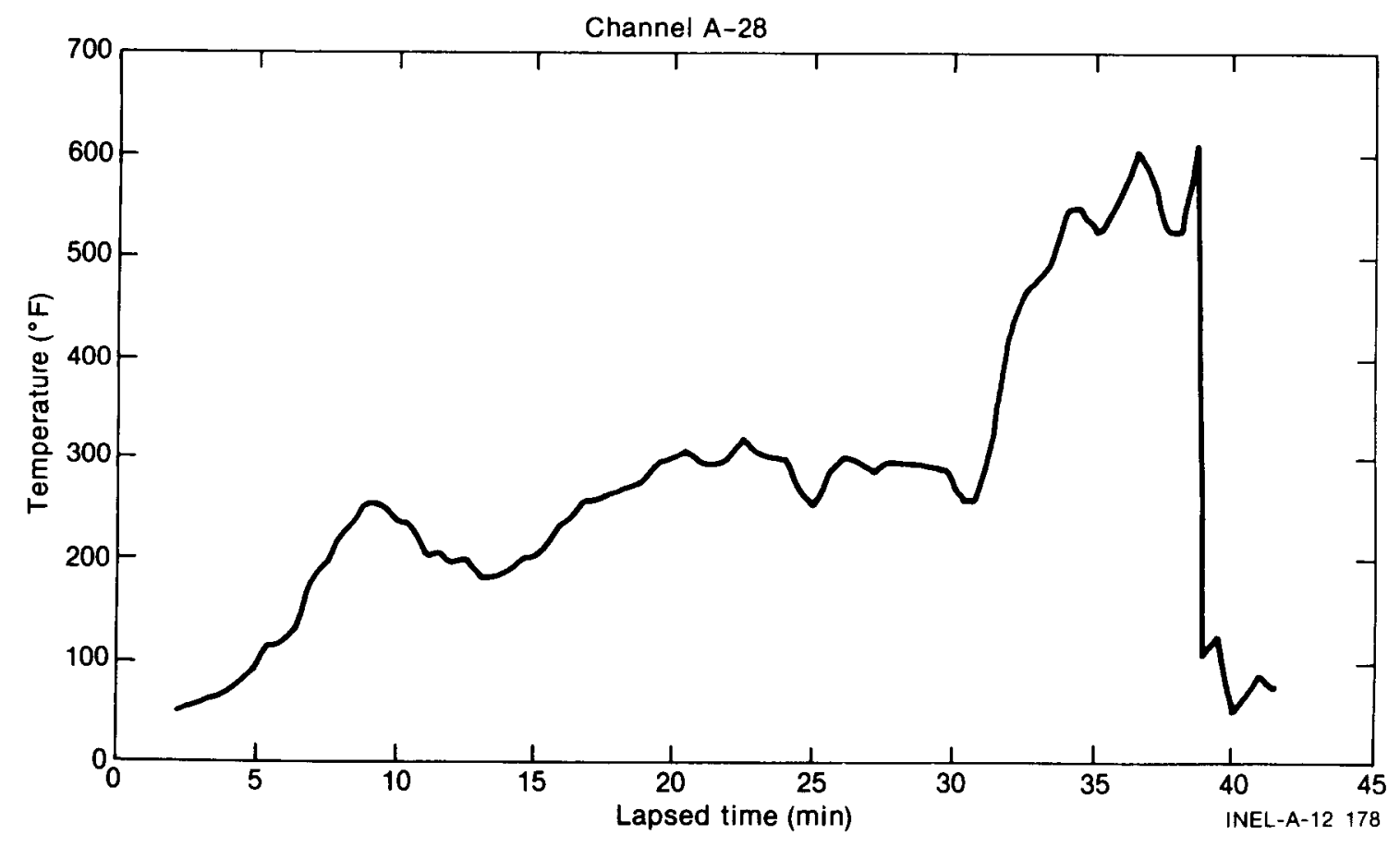

Fig. 40 Box $\mathrm{C} 2$ end face. 


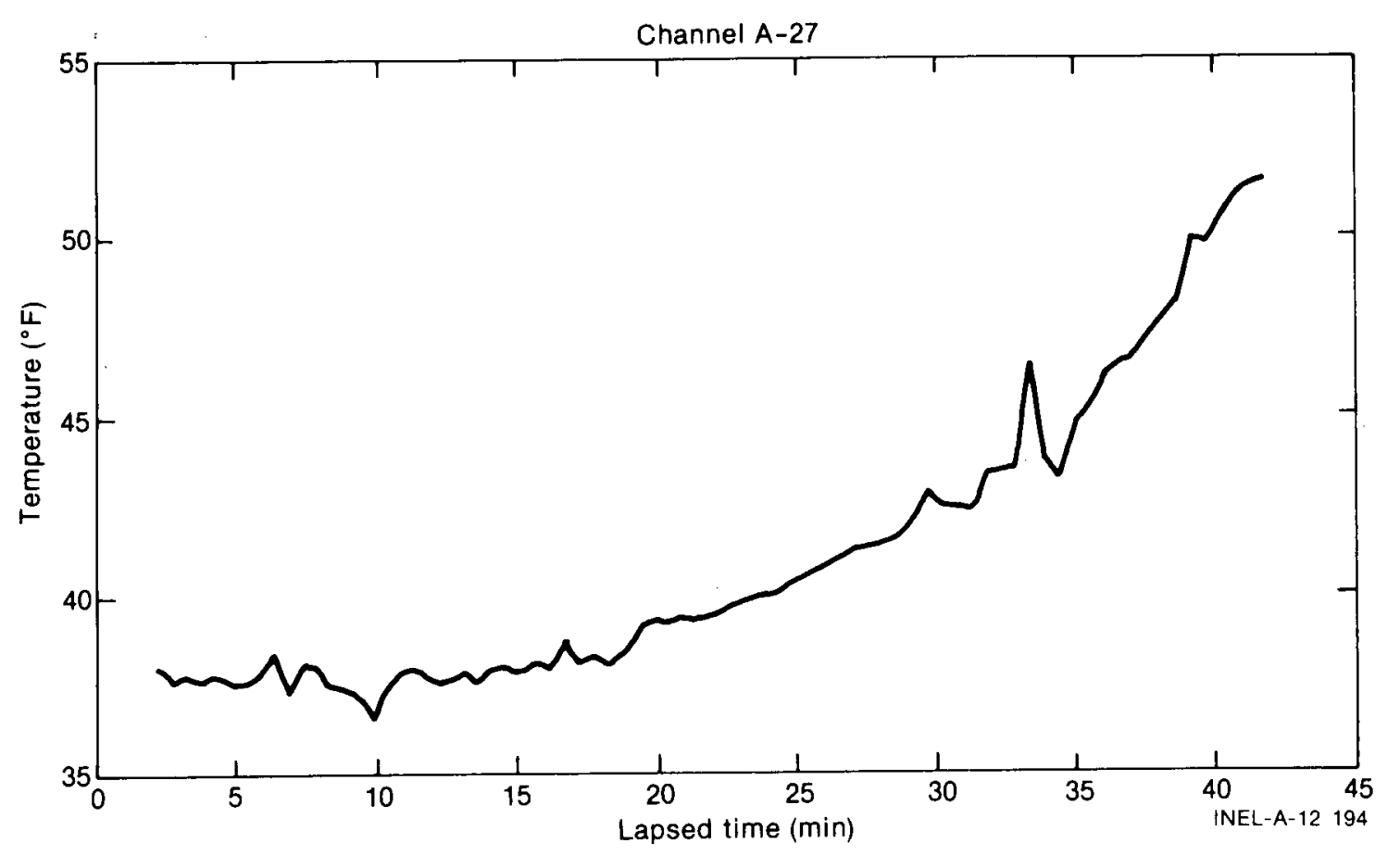

Fig. 41 Box C2 inside.

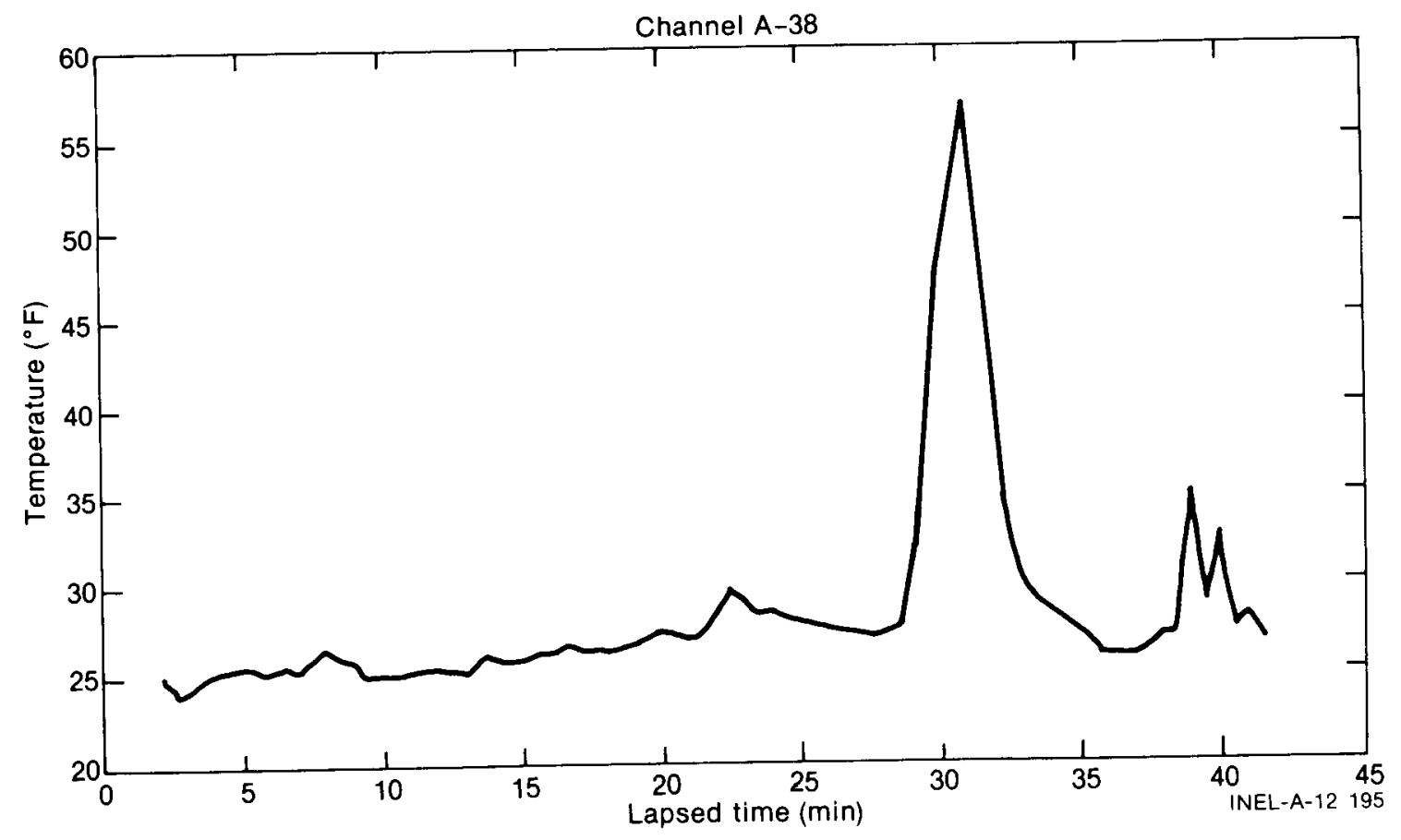

Fig. 42 Box C2/D2 flue. 


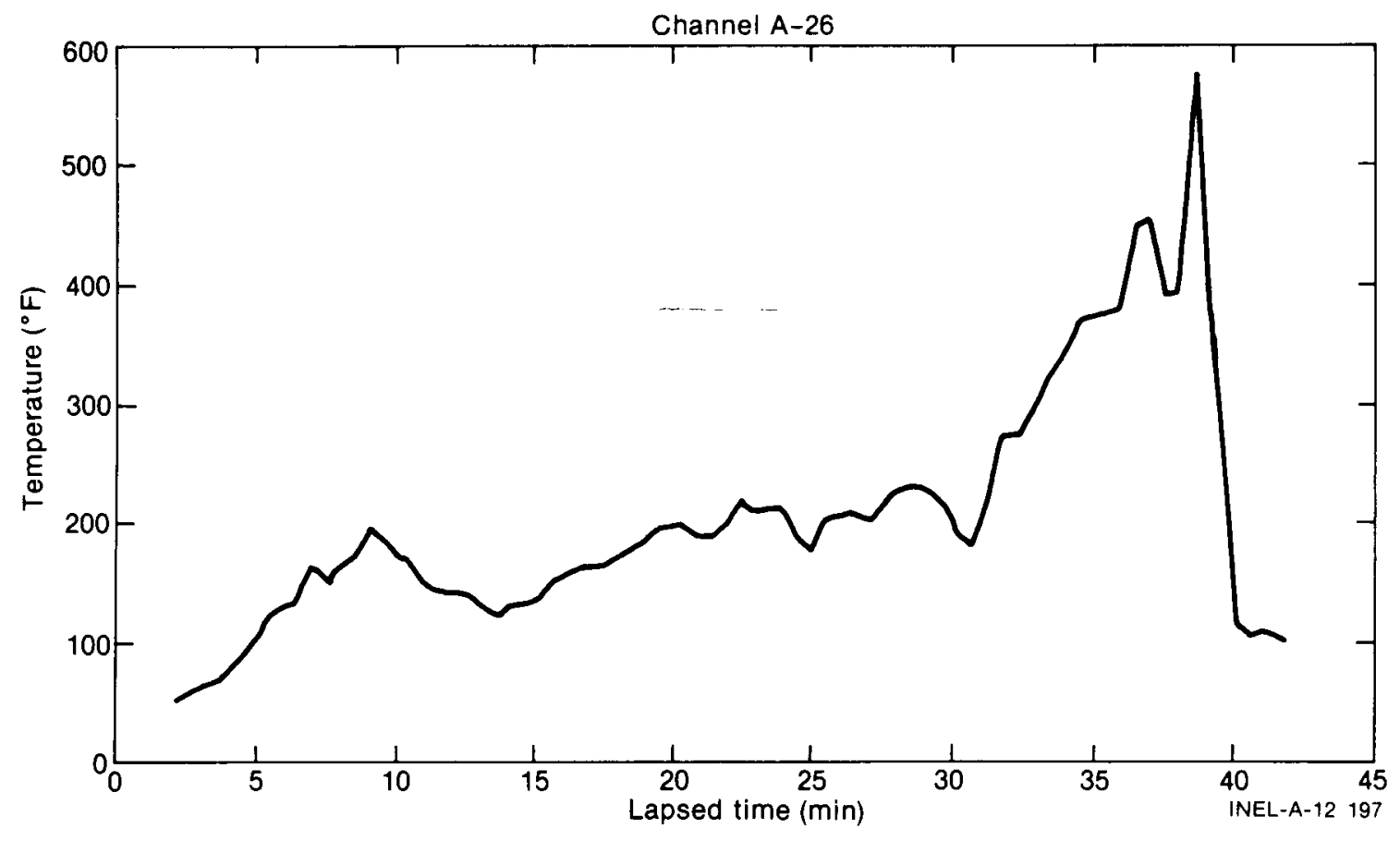

Fig. 43 Box C3 end face.

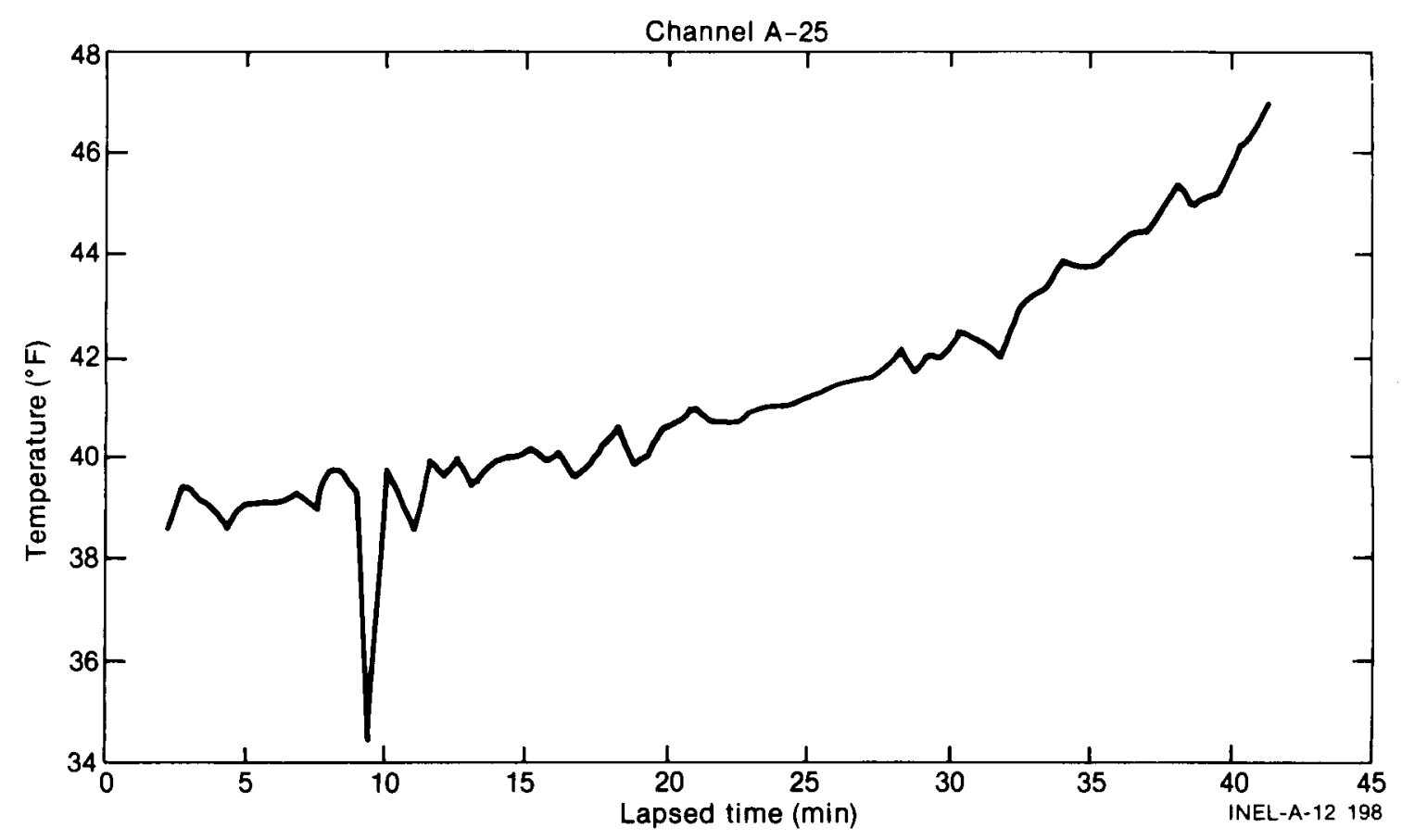

Fig. 44 Box C3 inside. 


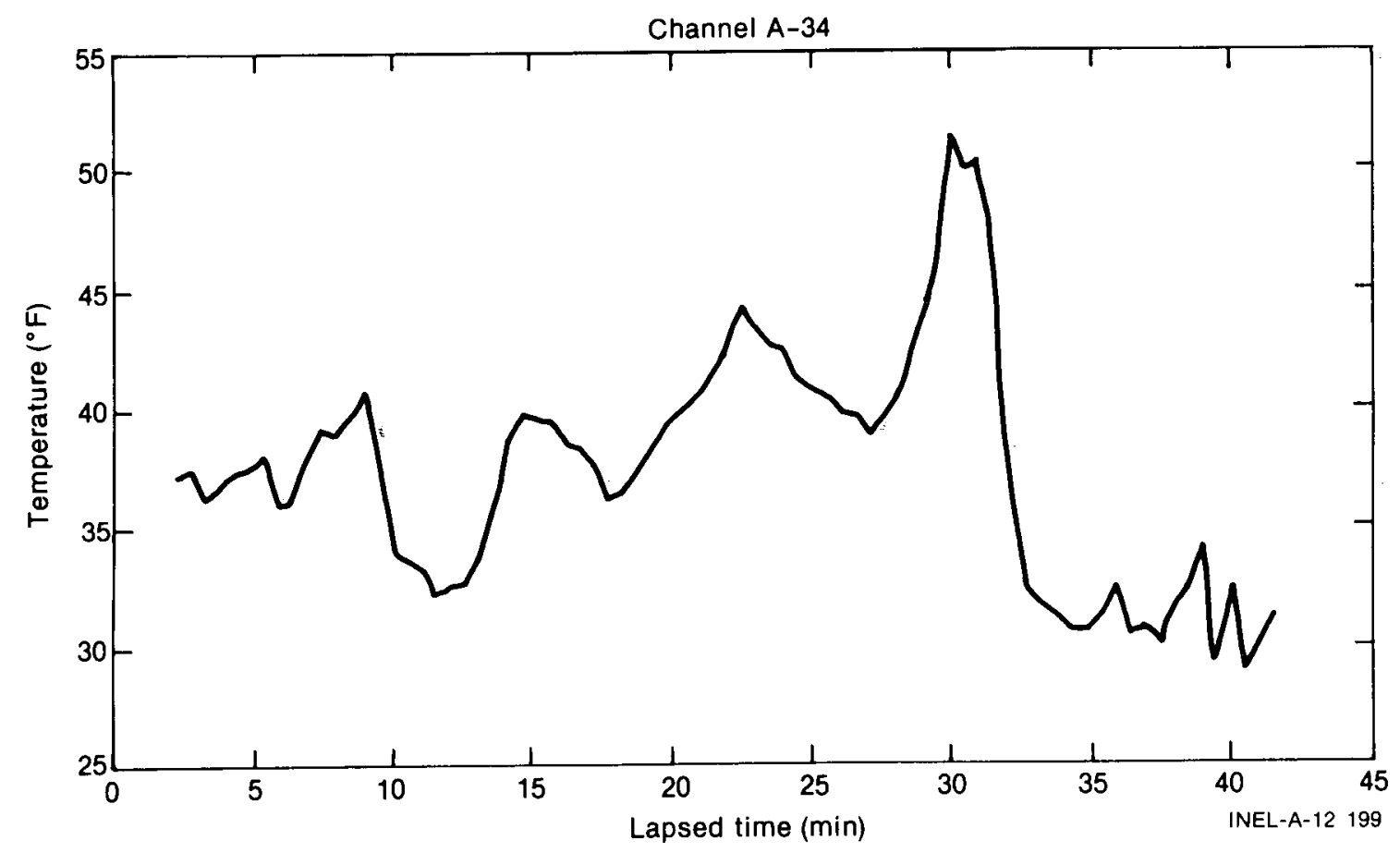

Fig. 45 Box C3/D3 flue.

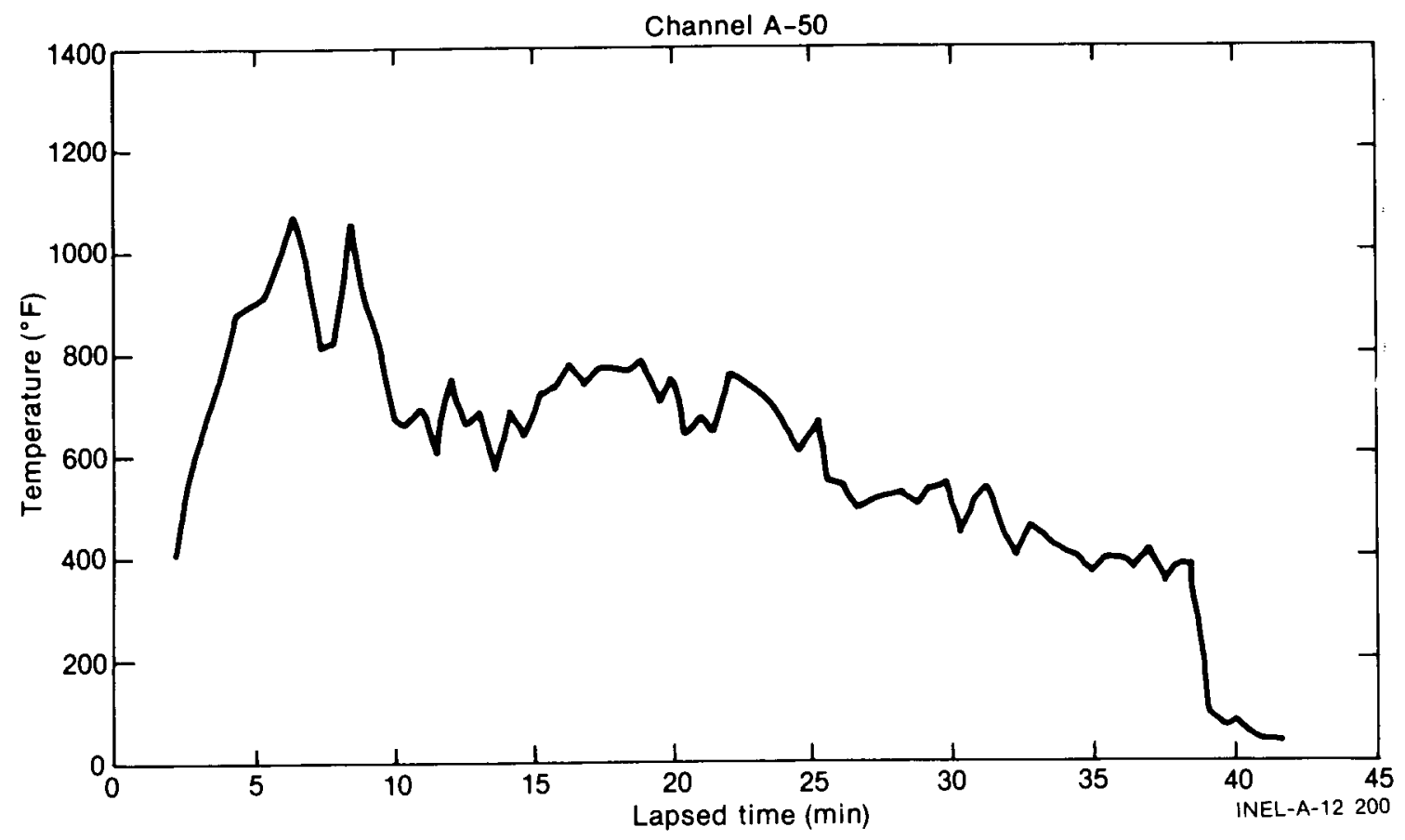

Fig. 46 TC TREE. 


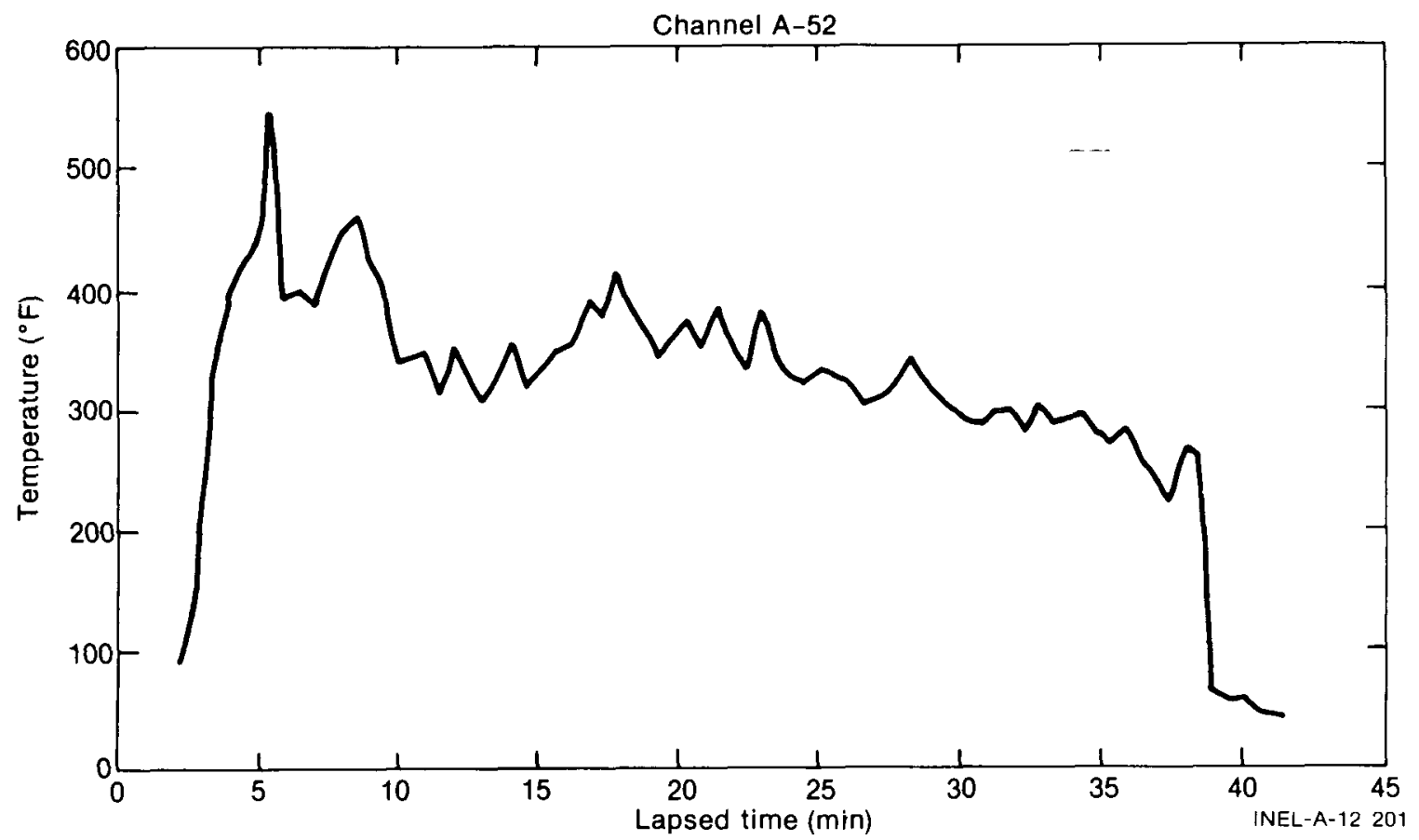

Fig. 47 TC TREE.

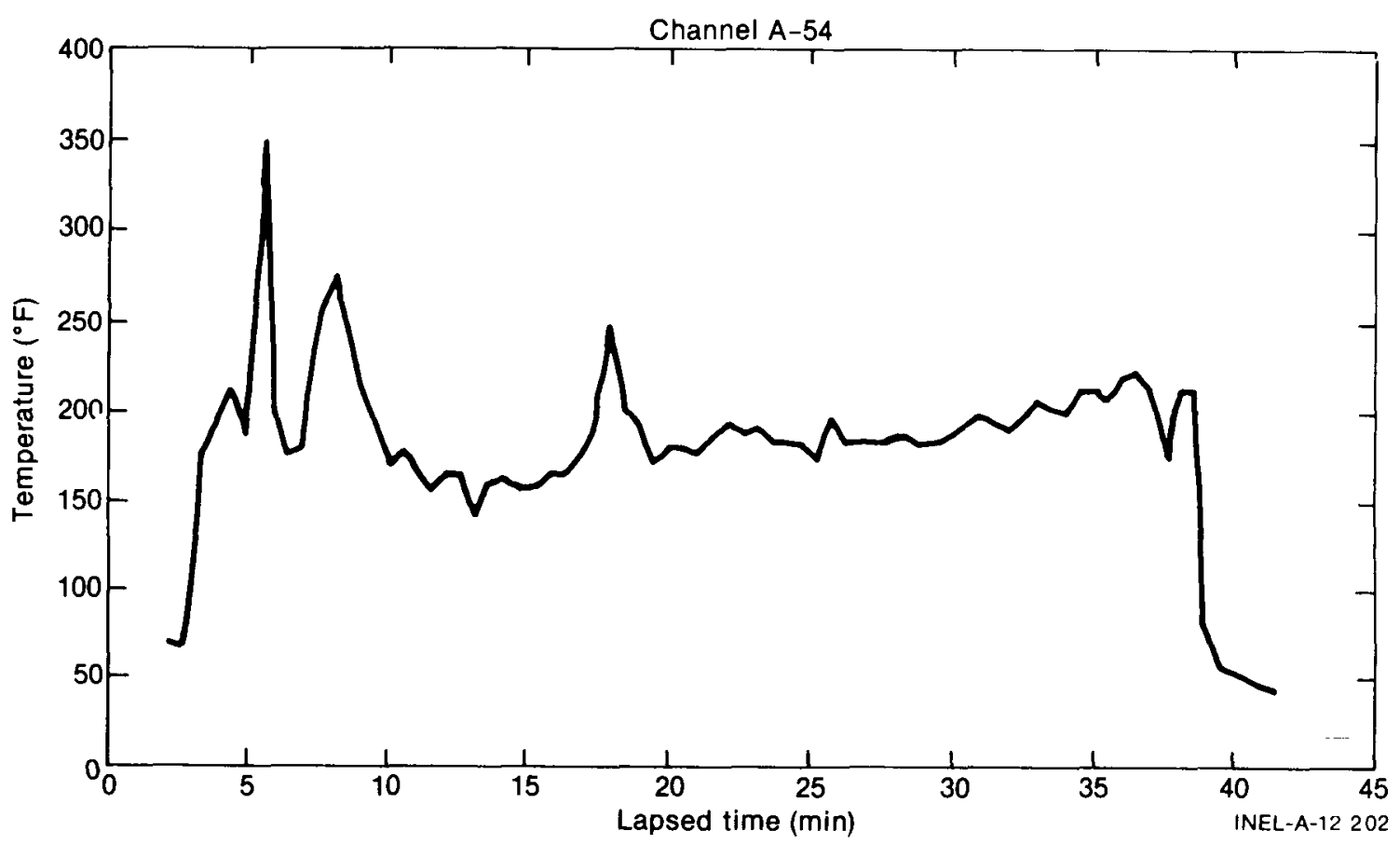

Fig. 48 TC TREE.

The fire test was extinguished using water at approximately 41 min into the test. The source was not consumed during this test. An estimated 94.61 ( $25 \mathrm{gal})$ of water was used to extinguish the fire.

At the completion of the test, a damage assessment was completed. Figures 49 through 52 were selected to display the damage to the waste containers resulting from Fire Test 1 . The overall damage that resulted from the fire can be seen.in Figure 49. The drums were knocked over to ensure the fire was extinguished. 


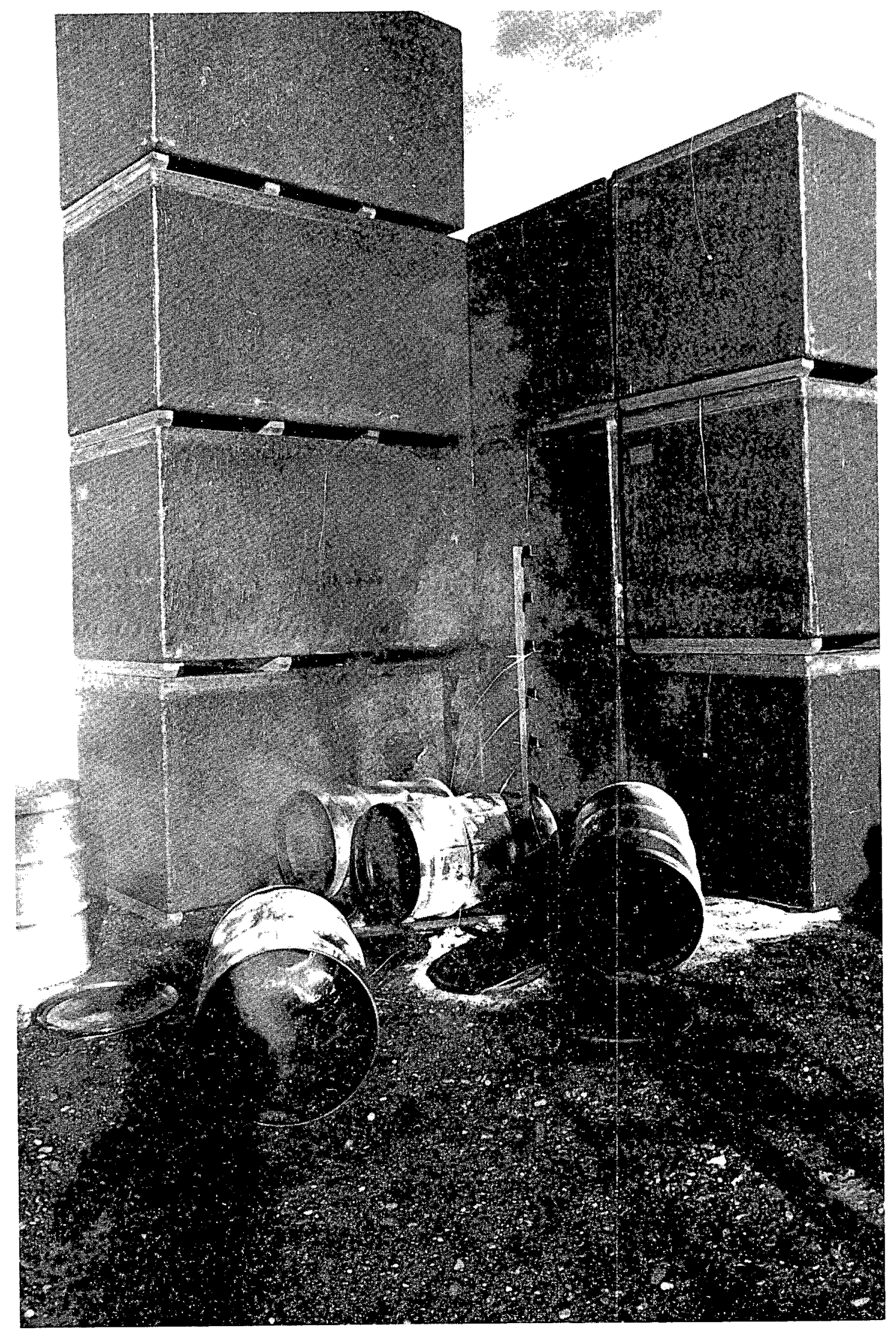

Fig. 49 Fire Test 1, inside corner after test. 


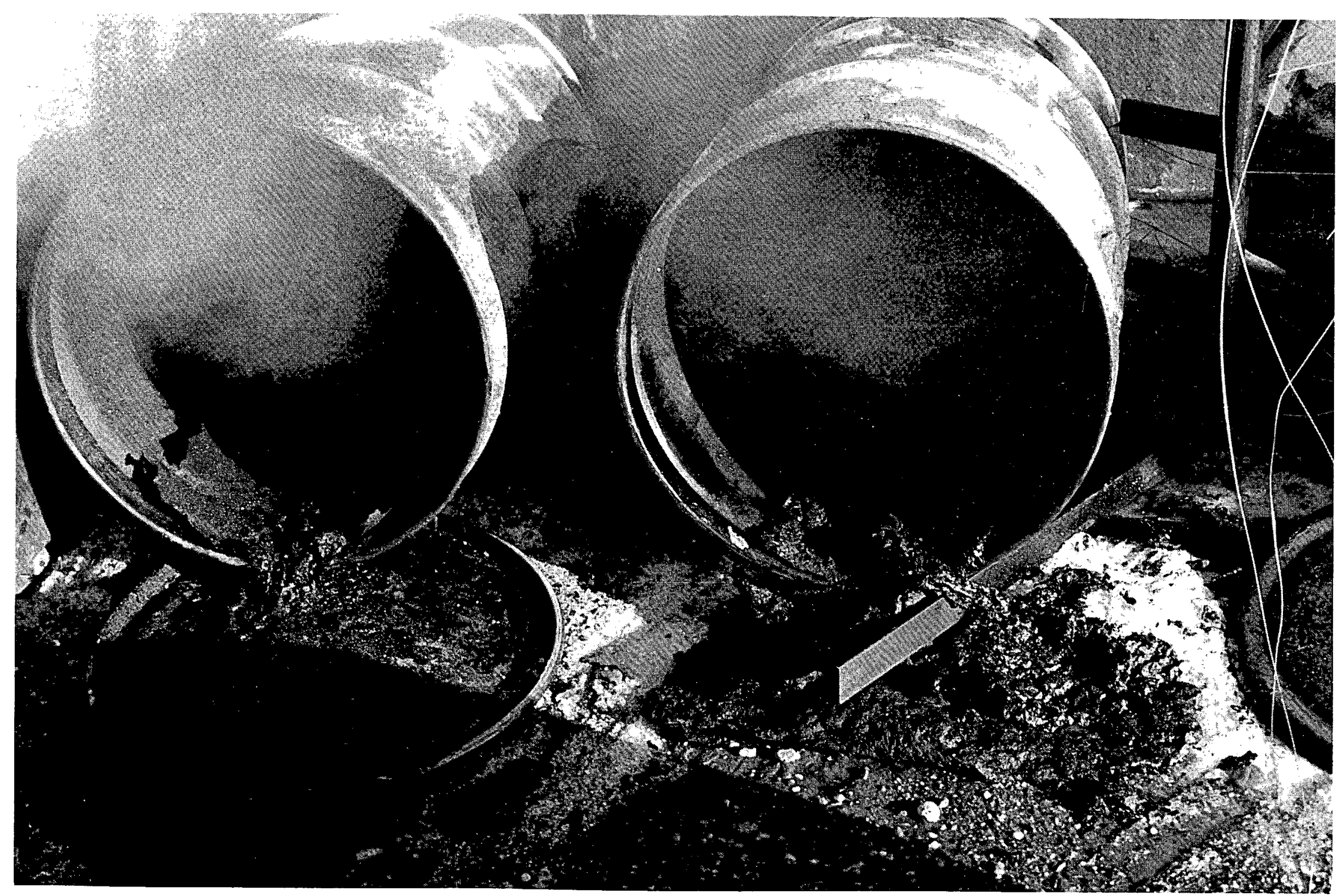

Fig. 50 Fire Test 1, rigid PVC liner remains after test. 


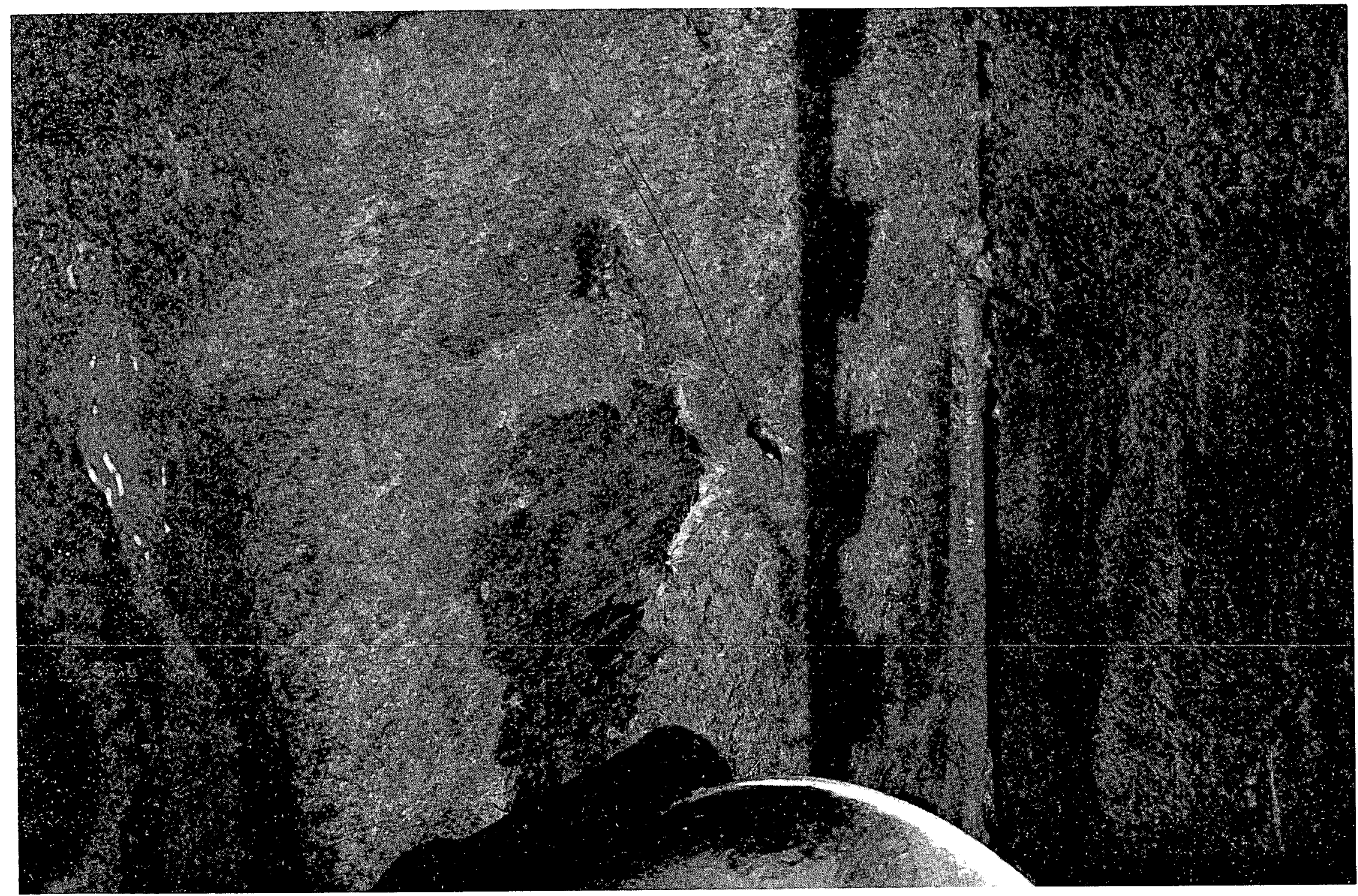

Fig. 51 Fire Test 1, inside corner view of boxes in row 1, stacks 1, 2, and 3 after test.

1 


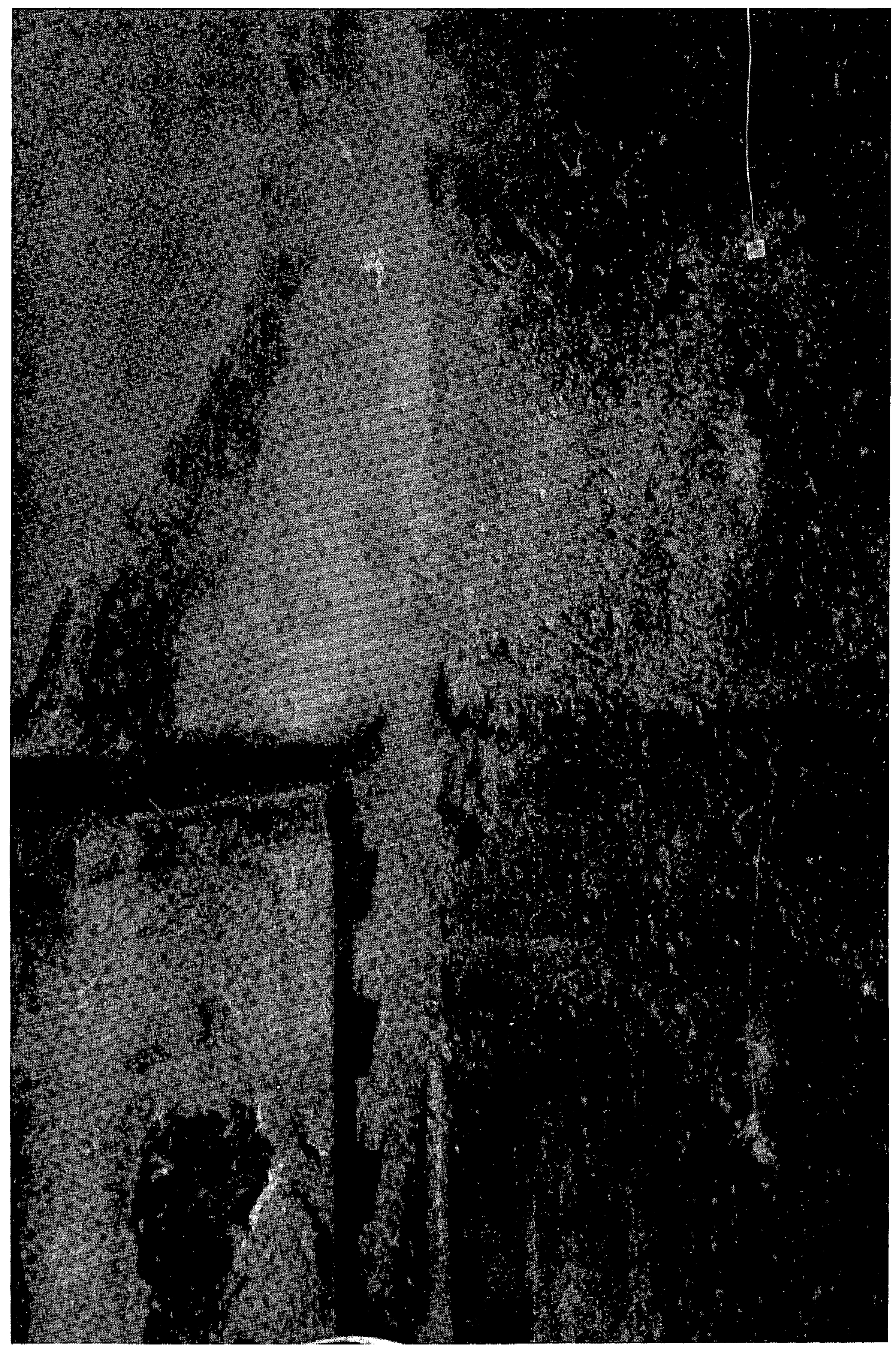

Fig. 52 Fire Test 1, inside corner view of boxes in rows 1 and 2, stacks 1, 2, and 3 after test. 
Figure 50 reveals the condition of the 90 -mm rigid poly liners followed the fire. Figure 51 reveals the portion of side facing of box A1, row 1, stack 1; this box was the only box where the FRP was completely missing and the plywood possessed an alligator char appearance. Figure 52 reveals the fire damage to the inside corner. In this photo, the skids between the boxes in rows 1 and 2 show heavy deep char. The box skids were not covered with FRP (roving strand fiber reinforced polyester).

Following the test, the source pan was cleaned of salt and unburned fuel in preparation for the second fire test. The salt removed from the pan revealed that a significant amount of \#2 diesel was still present; that is, it was estimated that only 20 to $40 \%$ of the source fuel had been consumed.

\section{FIRE TEST 2}

The source used for this test was 15.11 ( 4 gal) of \#2 diesel in an otherwise empty steel source pan. Table VII, Fire Test 2 TC Data Summation, was used to determine the significant TC data obtained during the test. Significant TC data are data which have a maximum temperature greater than $250^{\circ} \mathrm{F}$ or data from TCs located in areas deemed significant for comparison purposes or flue effects. Using this criteria and Table VII, the following Table VIII, presents TCs that are considered significant temperature data for Fire Test 2. Figures 53 to 71 show TC temperature data for Fire Test 2.

The second fire test was allowed to burn itself out, which it did approximately $75 \mathrm{~min}$ into the test. The ignition source was consumed in approximately $15 \mathrm{~min}$.

At the completion of the test a damage assessment was completed. Figures 72 through 75 were selected to display the damage to waste containers resulting from Fire Test 2. Figure 72 reveals the damage sustained at the mating corners of the DOT 7A boxes located in rows 1 and 2 , stacks 3 and 4 , and the fire retardant plywood separator between the drums in rows 1 and 2 . Figure 73 is a close up view of what remained of the fire retardant plywood between rows 1 and 2 in the outside drum stack. The fire retardant plywood separating the drums in row 2 from row 3 was scorched and revealed some burning along the edge facing the boxes in stacks 3 and 4 . Figure 74 reveals the overall condition of the DOT 7A FRP-coated boxes on the inside of the corner after the drums were removed. Figure 75 exposes the breech observed in the upper right side corner of the box in row 1, stack 3 . This breech was discovered in the process of extinguishing the embers remaining in the box skids on row 2, stacks 3 and 4 . This is also the same corner displayed in Figure 72. The above figures also reveal the deterioration of the box skids exposed to the fire. The box skids were not covered with FRP.

TABLE VII

FIRE TEST 2, TC DATA SUMMATION

\begin{tabular}{cccc}
\multicolumn{4}{c}{ Unit of Measure $\left({ }_{F}\right)$} \\
Channe1 Number & $\begin{array}{c}\text { Number of } \\
\text { Samples }\end{array}$ & $\begin{array}{c}\text { Minimum } \\
\text { Value }\end{array}$ & $\begin{array}{c}\text { Maximum } \\
\text { Value }\end{array}$ \\
\cline { 2 - 3 } A- 0 & 169 & 19.8 & 145.3 \\
A- & 168 & 17.3 & 22.5 \\
A- 2 & 168 & 17.2 & 21.5 \\
A- 3 & 168 & 19.3 & 42.9 \\
A- 4 & 168 & 20.0 & 69.0 \\
A- 5 & 169 & 8.9 & 33.7 \\
A- 6 & 169 & 14.8 & 50.4 \\
A- 7 & 169 & 26.1 & 30.2
\end{tabular}


TABLE VII (continued)

Unit of Measure (OF)

\begin{tabular}{|c|c|c|c|}
\hline Channel Number & $\begin{array}{c}\text { Number of } \\
\text { Samples } \\
\end{array}$ & $\begin{array}{c}\text { Minimum } \\
\text { Value } \\
\end{array}$ & $\begin{array}{c}\text { Maximum } \\
\text { Value } \\
\end{array}$ \\
\hline$A-8$ & 169 & -15.0 & 27.2 \\
\hline$A-9$ & 169 & 18.5 & 23.6 \\
\hline$A-10$ & 169 & 18.3 & 22.6 \\
\hline$A-11$ & 169 & 20.8 & 33.9 \\
\hline$A-12$ & 169 & 25.2 & 45.5 \\
\hline$A-13$ & 169 & 34.1 & 37.4 \\
\hline Broken $A-14$ & 169 & 19.2 & 327.0 \\
\hline$A-15$ & 169 & 18.9 & 21.6 \\
\hline$A-16$ & 169 & 24.7 & 26.8 \\
\hline$A-17$ & 169 & 19.6 & 22.8 \\
\hline$A-18$ & 169 & 19.7 & 22.9 \\
\hline$A-19$ & 171 & 18.8 & 23.3 \\
\hline$A-20$ & 170 & 17.3 & 19.9 \\
\hline$A-21$ & 170 & 14.7 & 21.1 \\
\hline$A-22$ & 169 & 20.6 & 22.7 \\
\hline$A-23$ & 169 & 17.5 & 19.9 \\
\hline$A-24$ & 169 & 17.1 & 19.1 \\
\hline$A-25$ & 170 & 22.4 & 26.0 \\
\hline$A-26$ & 169 & 22.1 & 120.0 \\
\hline$A-27$ & 169 & 18.5 & 35.3 \\
\hline$A-28$ & 169 & 17.7 & 239.2 \\
\hline$A-29$ & 169 & 18.6 & 84.1 \\
\hline$A-30$ & 169 & 19.5 & 1374.4 \\
\hline$A-31$ & 169 & 29.3 & 39.2 \\
\hline$A-32$ & 169 & 11.8 & 20.9 \\
\hline$A-33$ & 169 & 24.4 & 46.7 \\
\hline$A-34$ & 169 & 17.6 & 20.3 \\
\hline$A-35$ & 169 & 17.9 & 20.0 \\
\hline$A-36$ & 169 & 25.8 & 63.8 \\
\hline$A-37$ & 169 & 16.8 & 21.4 \\
\hline Void A-38 & 169 & ---- & 0.0 \\
\hline Void A-39 & 169 & --- & 0.0 \\
\hline
\end{tabular}




\begin{tabular}{|c|c|c|c|}
\hline \multicolumn{4}{|c|}{ Unit of Measure $\left(O_{F}\right)$} \\
\hline Channel Number & $\begin{array}{c}\text { Number of } \\
\text { Samples } \\
\end{array}$ & $\begin{array}{c}\text { Minimum } \\
\text { Value } \\
\end{array}$ & $\begin{array}{c}\text { Maximum } \\
\text { Value } \\
\end{array}$ \\
\hline$A-40$ & 169 & 20.3 & 1452.8 \\
\hline$A-41$ & 169 & 20.0 & 1435.2 \\
\hline$A-42$ & 169 & 19.6 & 1352.7 \\
\hline$A-43$ & 169 & 21.6 & 1233.5 \\
\hline$A-44$ & 169 & 20.8 & 722.1 \\
\hline$A-45$ & 169 & 19.7 & 612.3 \\
\hline$A-46$ & 169 & 17.8 & 20.9 \\
\hline$A-47$ & 169 & ---- & 0.0 \\
\hline$A-48$ & 169 & ---- & 0.0 \\
\hline$A-\dot{4} 9$ & 169 & ---- & 0.0 \\
\hline$A-50$ & 169 & $---\infty$ & 0.0 \\
\hline
\end{tabular}

TABLE VIII

SIGNIFICANT TEMPERATURE DATA FOR FIRE TEST 2

Channel Number

0

3

4

5

7

22

25

26

27

28

34

29

30

37

\section{Location}

Box Al side face

Box Al inside

Box A2 side face

Box B2 End corner

Box A2 inside

Box B1 inside

Box C3 inside

Box C 3 end face

Box C2 inside

Box C2 end face

Box C2/D2 flue

Box $\mathrm{Cl}$ inside

Box $\mathrm{Cl}$ end face

Box C1/D1 flue

\section{Figure}

53

54

55

56

57

58

59

60

61

62

63

64

65

66 
TABLE VIII (continued)

\begin{tabular}{clll}
\hline Channe1 Number & \multicolumn{1}{c}{ Location } & Figure \\
\cline { 2 - 3 } 33 & Box D2 inside & 67 \\
36 & Box D1 inside & 68 \\
40 & TC Tree & 69 \\
42 & TC Tree & 70 \\
44 & TC Tree & 71 \\
\hline
\end{tabular}

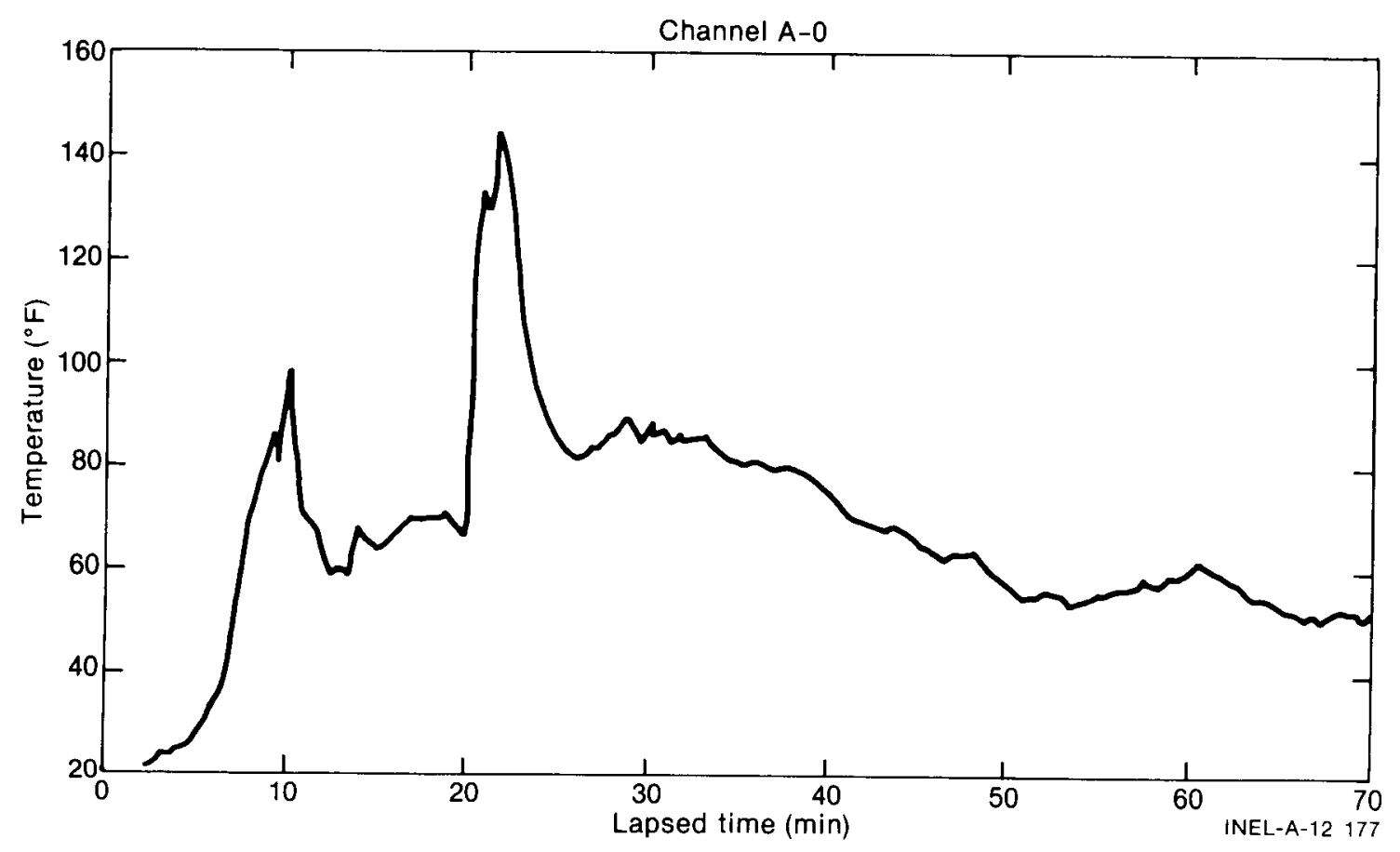

Fig. 53 Box A1 side face. 


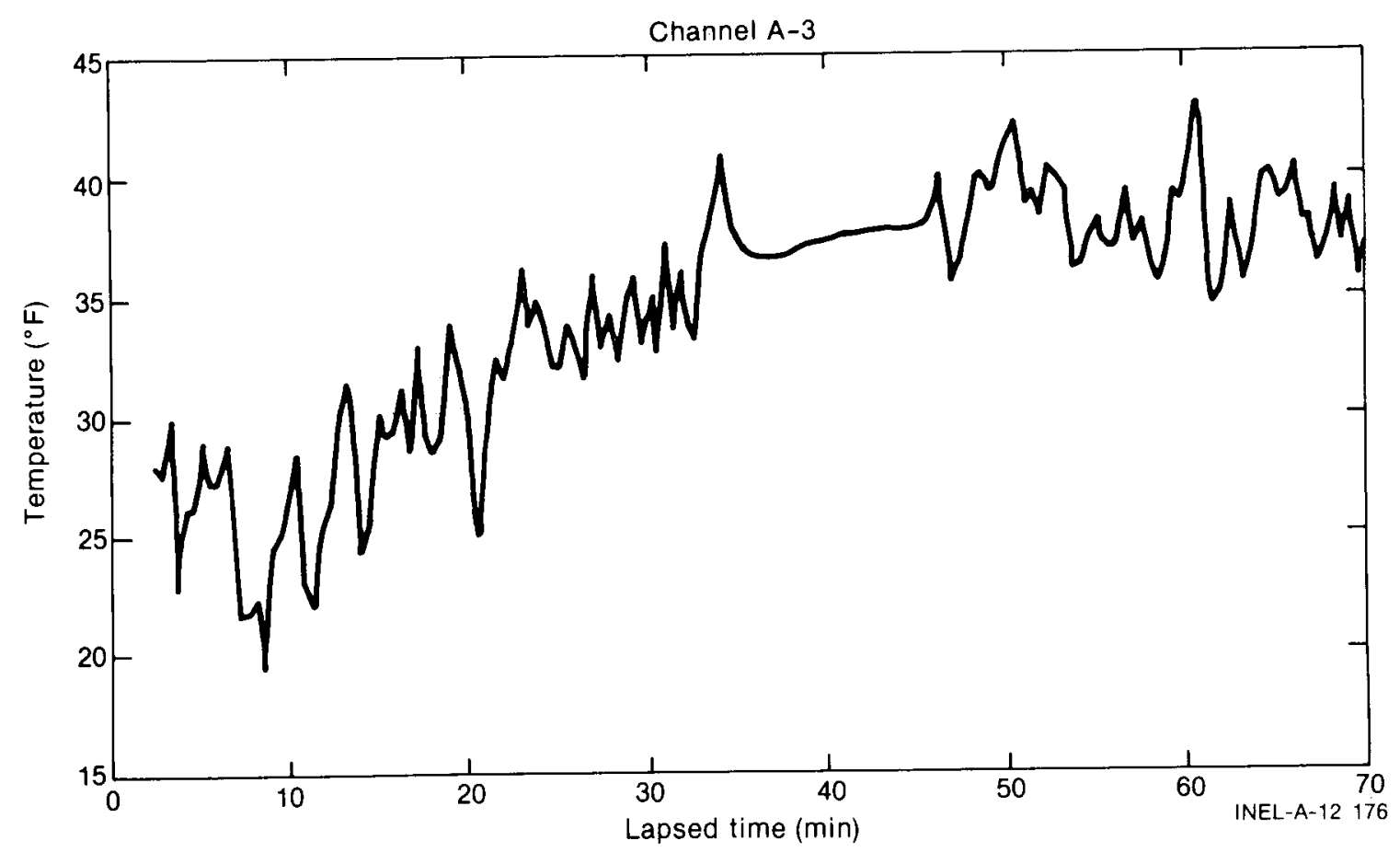

Fig. 54 Box A1 inside.

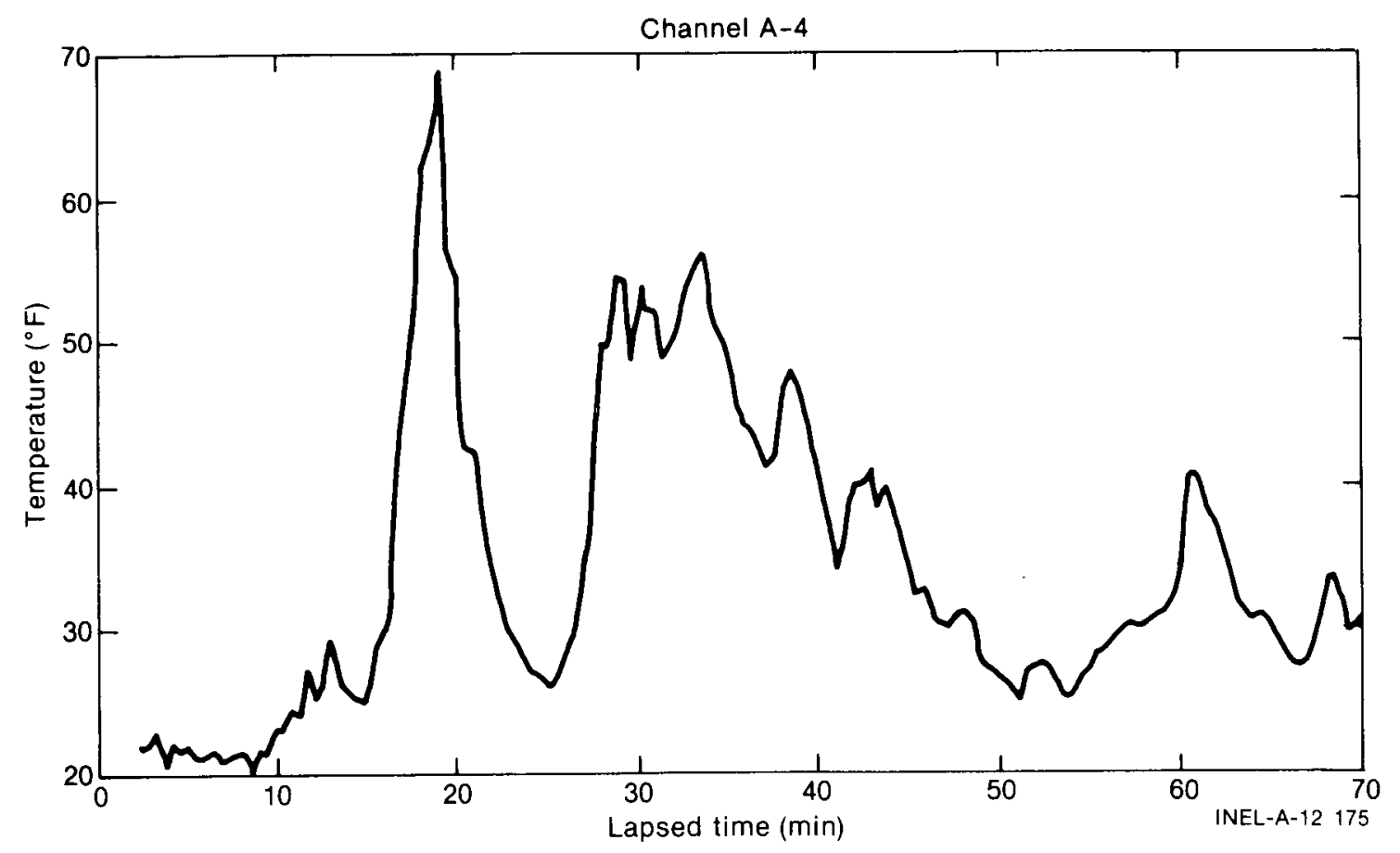

Fig. 55 Box A2 side face. 


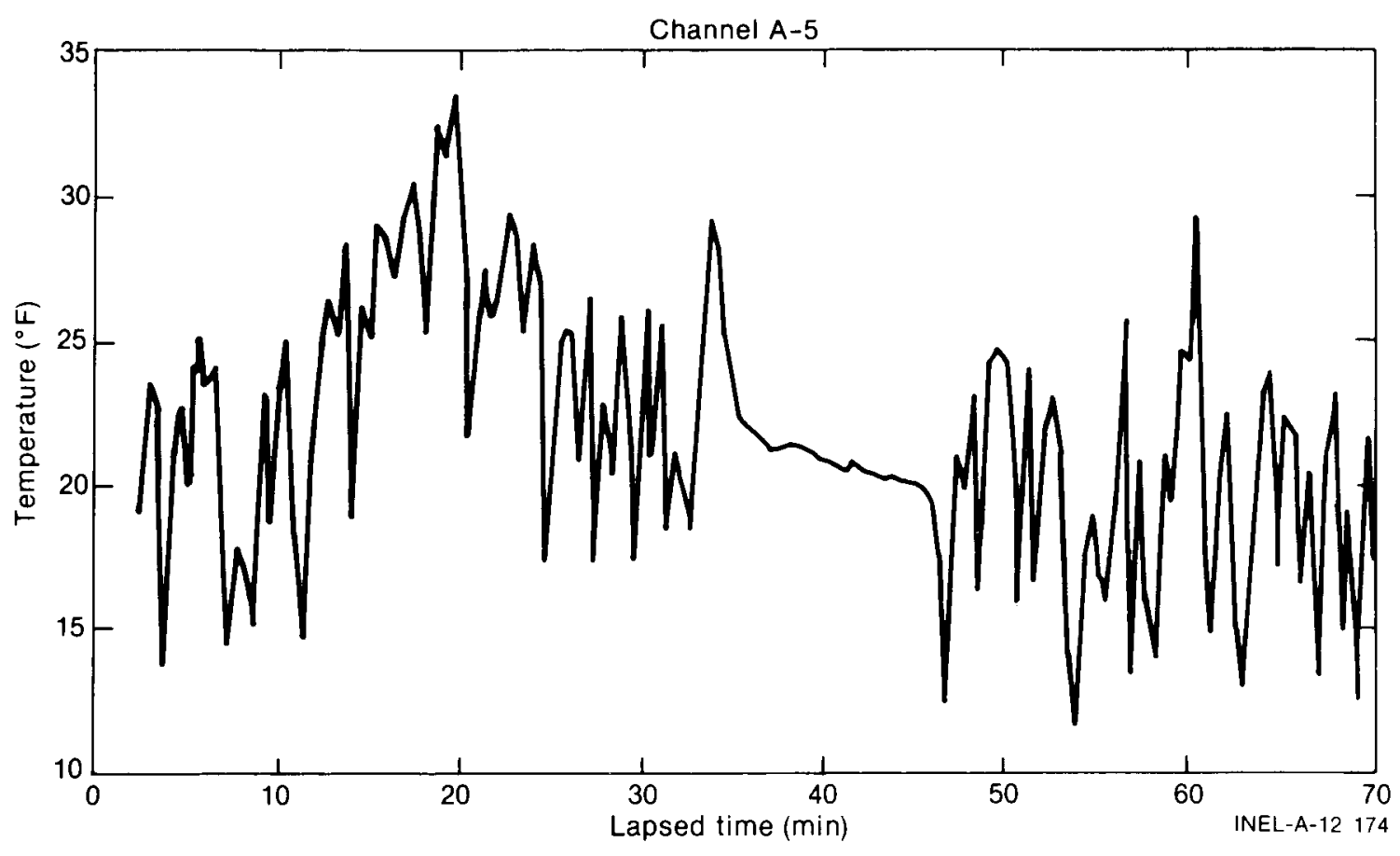

Fig. 56 Box B2 end corner.

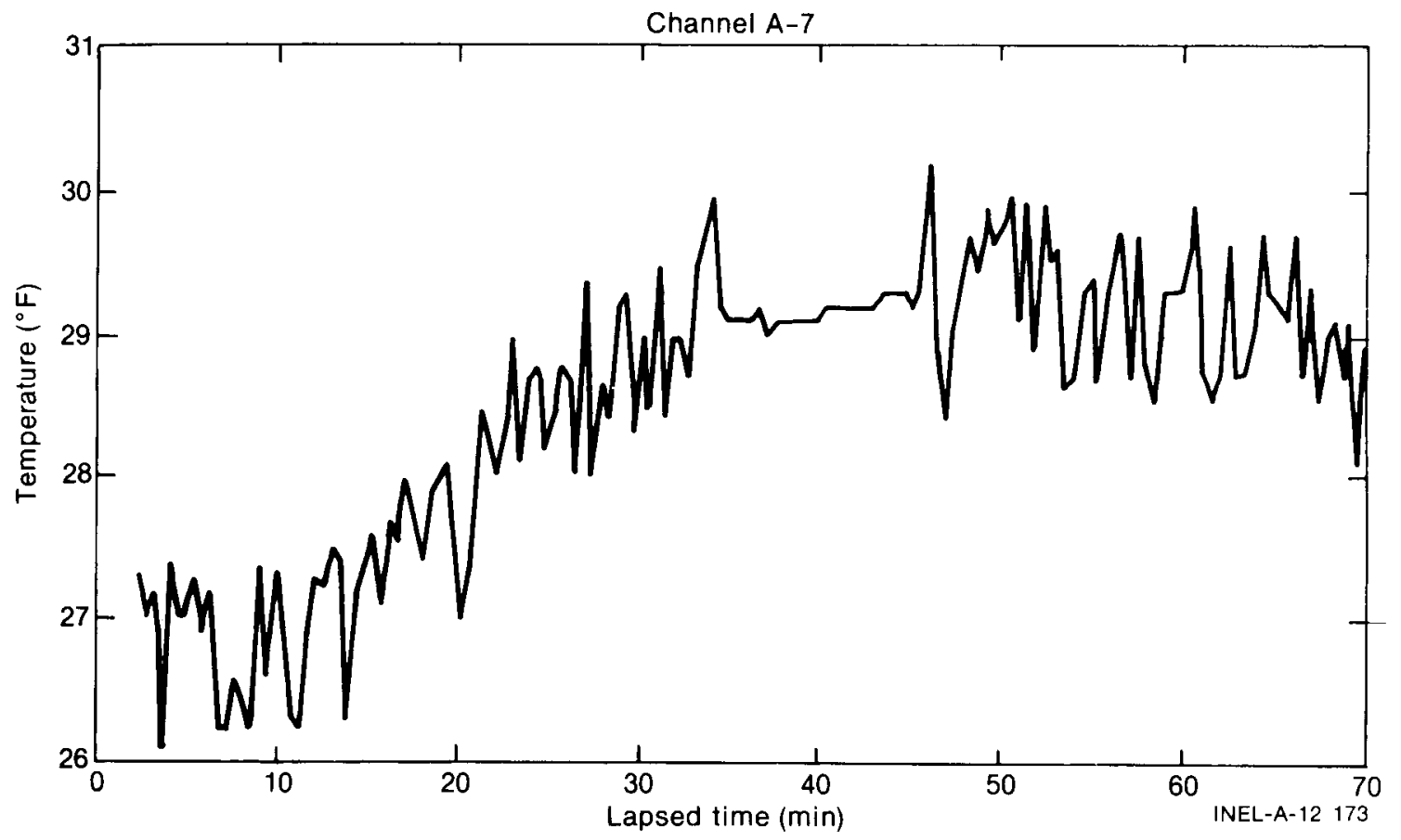

Fig. 57 Box A2 inside. 


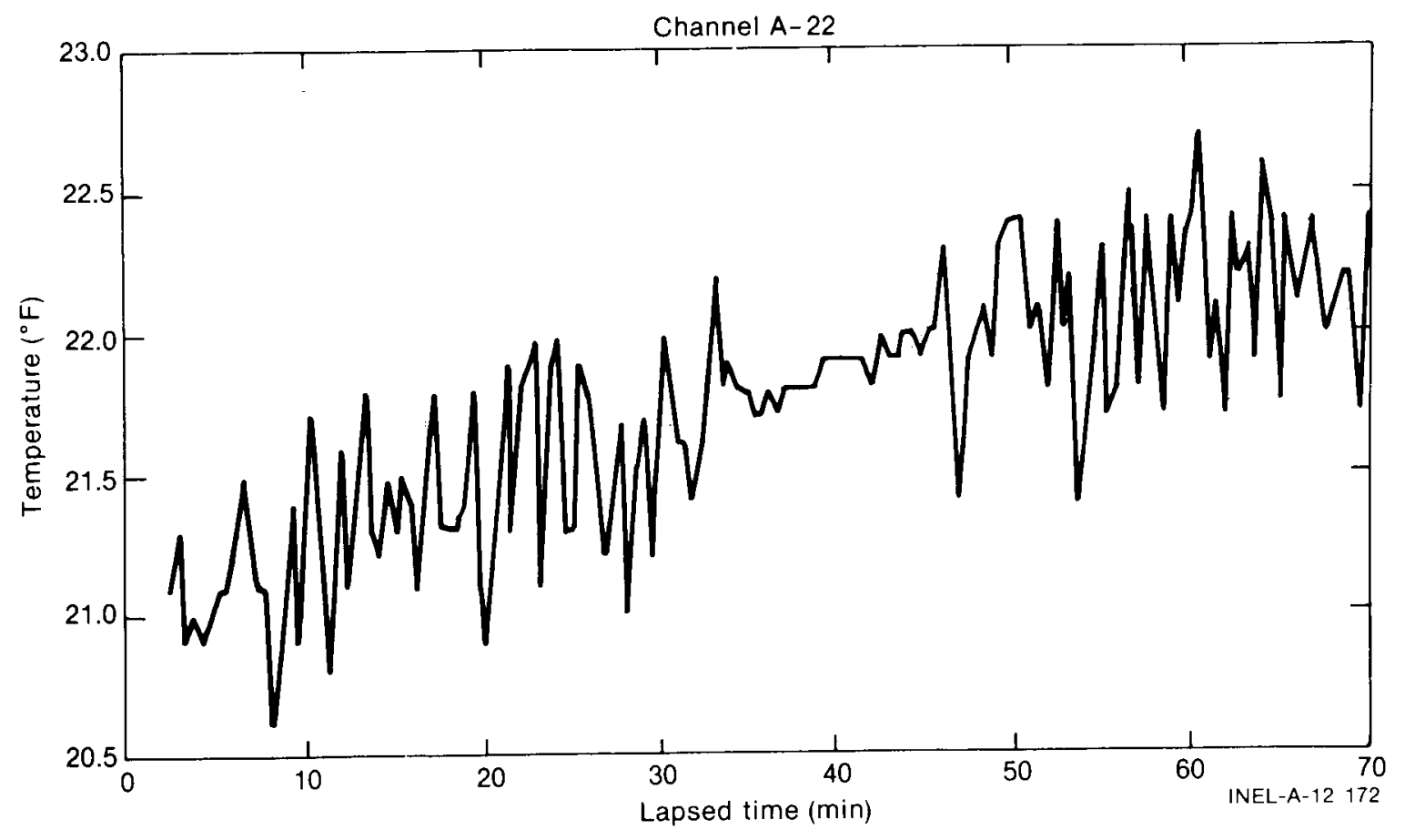

Fig. 58 Box B1 inside.

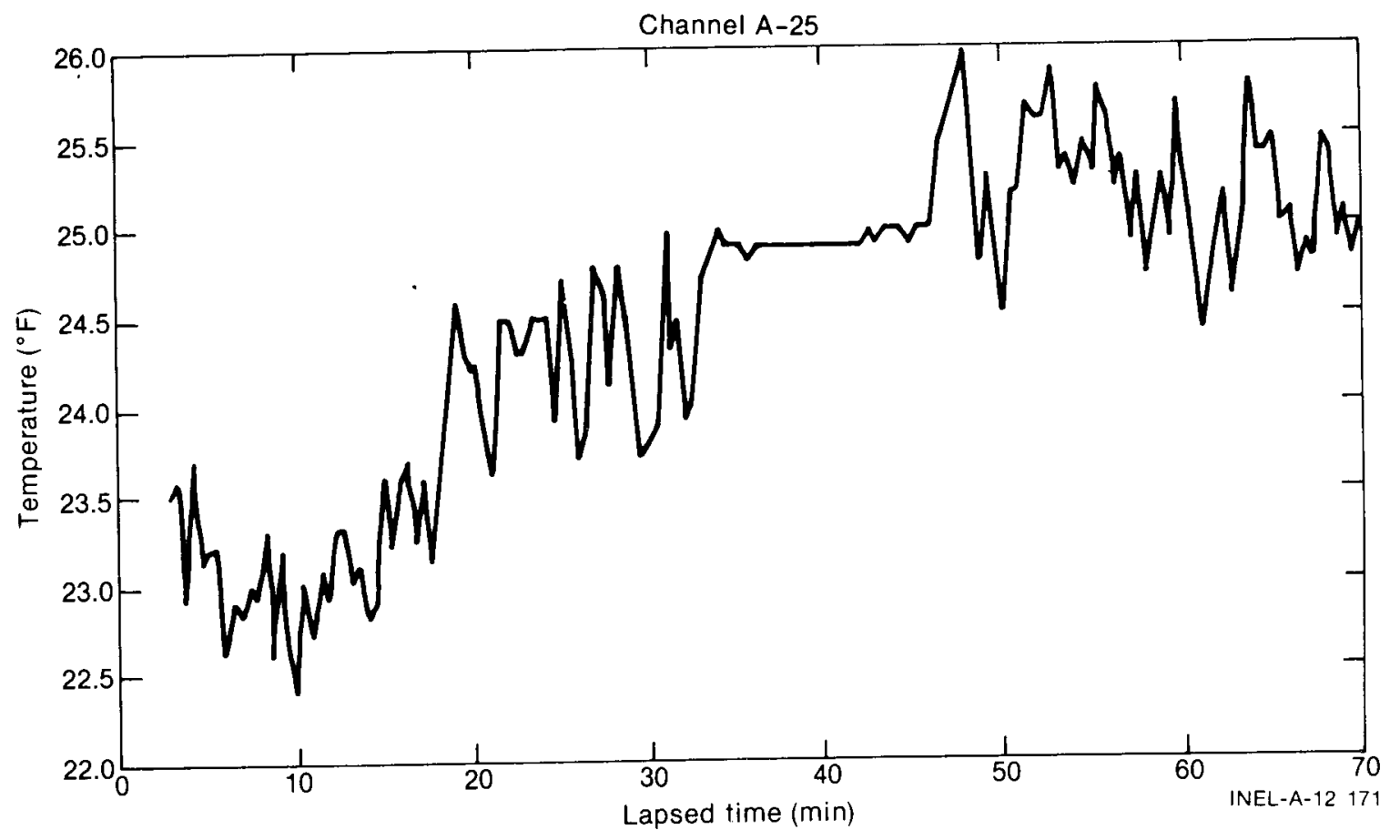

Fig. 59 Box C3 inside. 


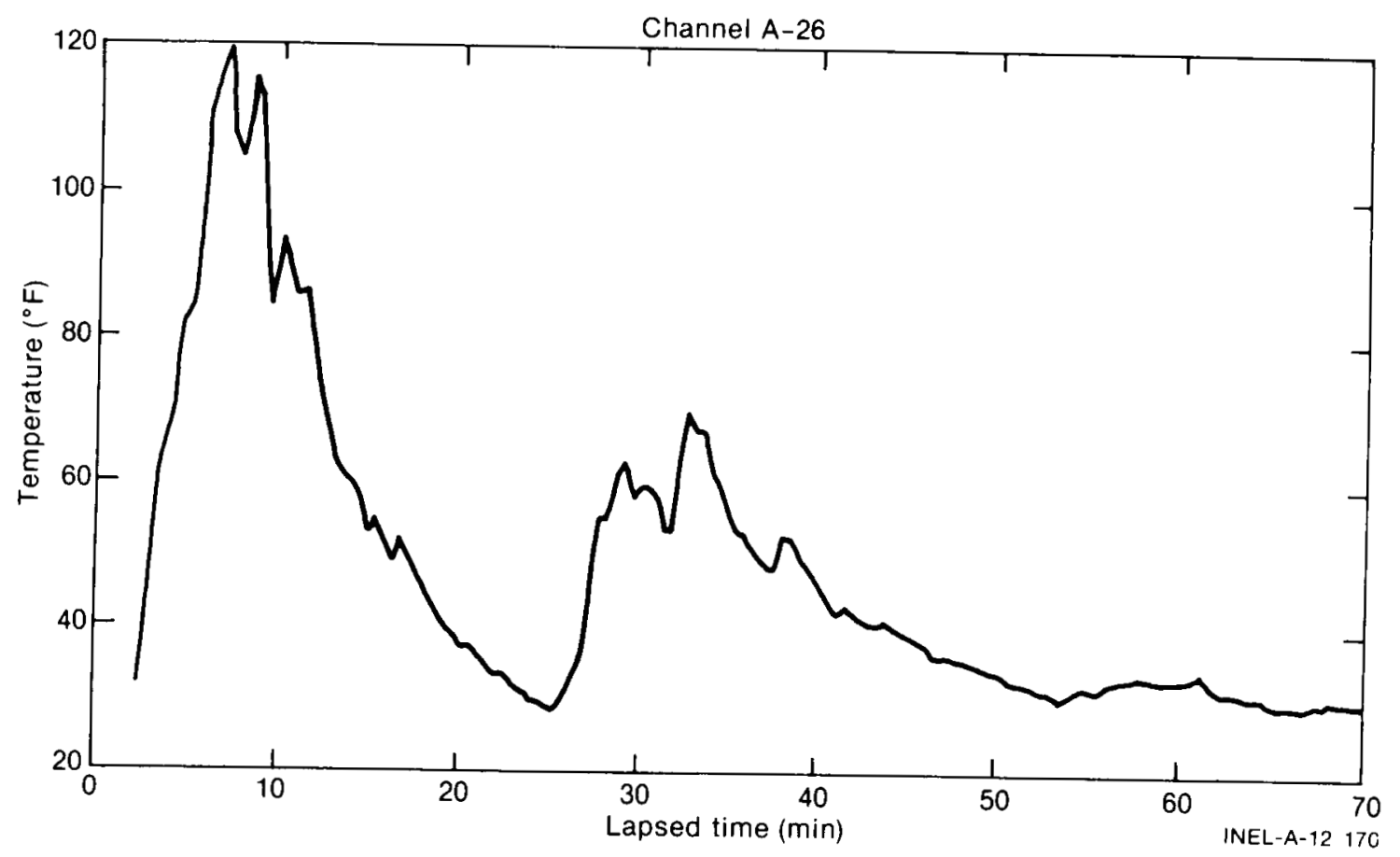

Fig. 60 Box C3 end face.

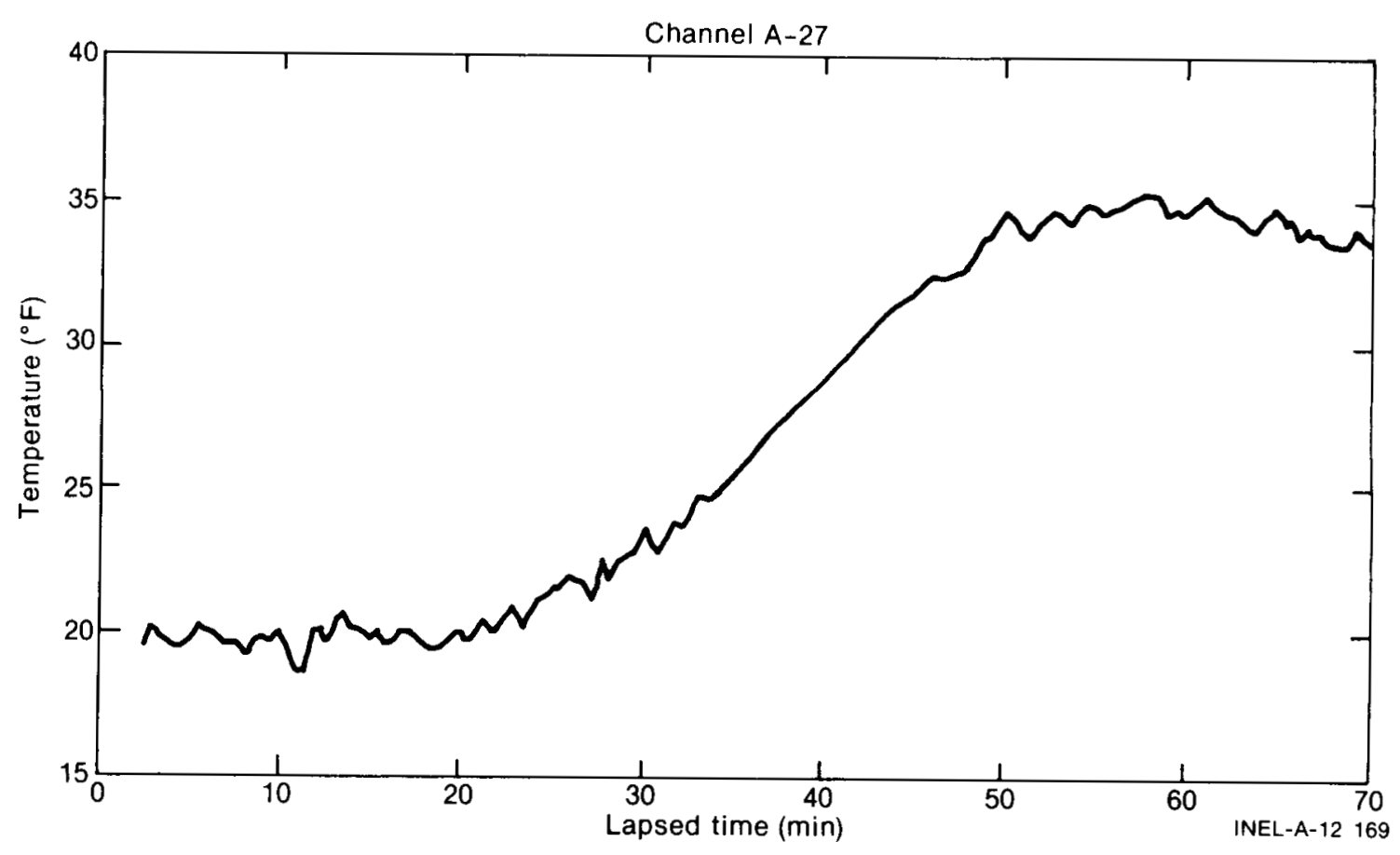

Fig. 61 Box C2 inside. 


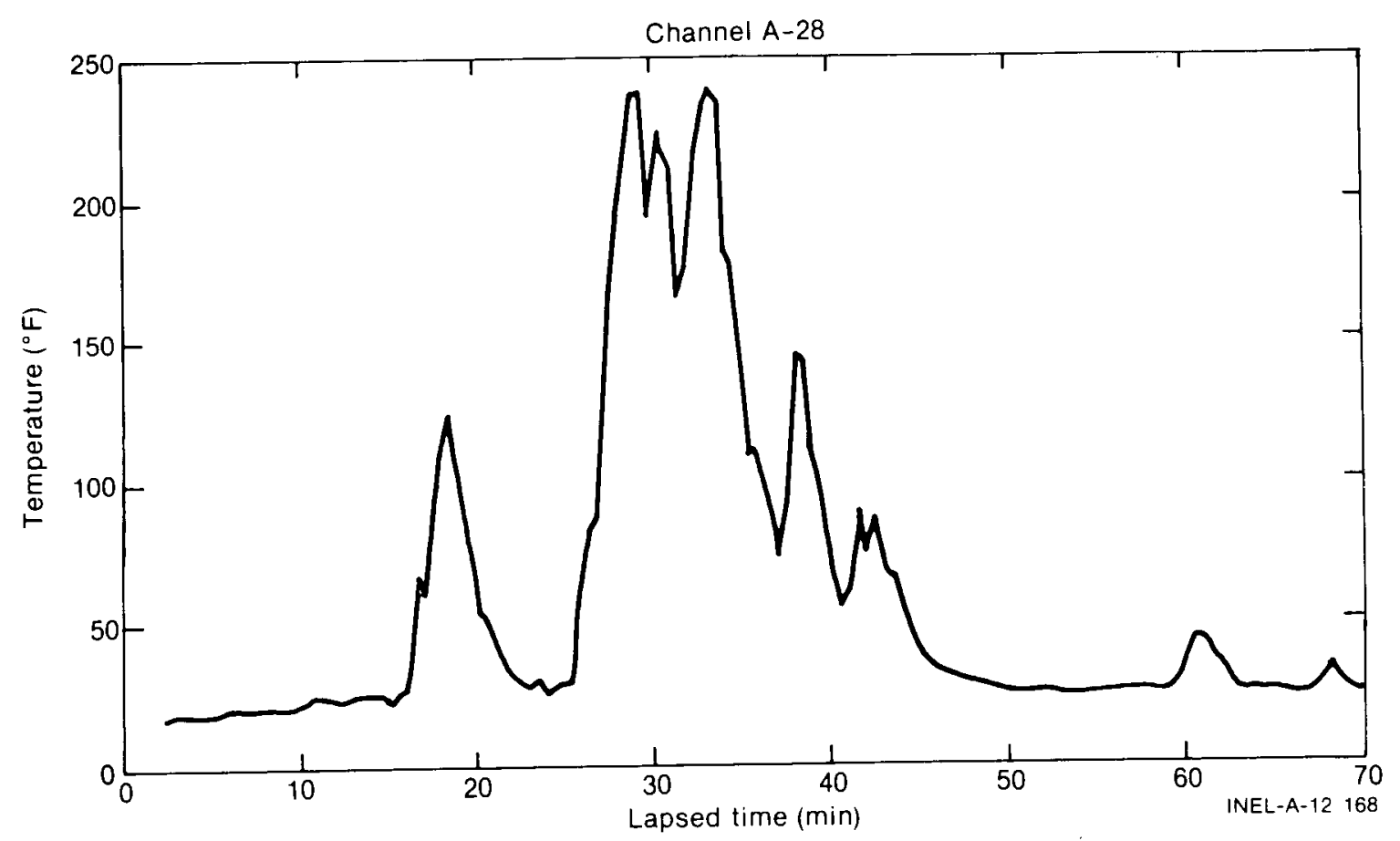

Fig. 62 Box C2 end face.

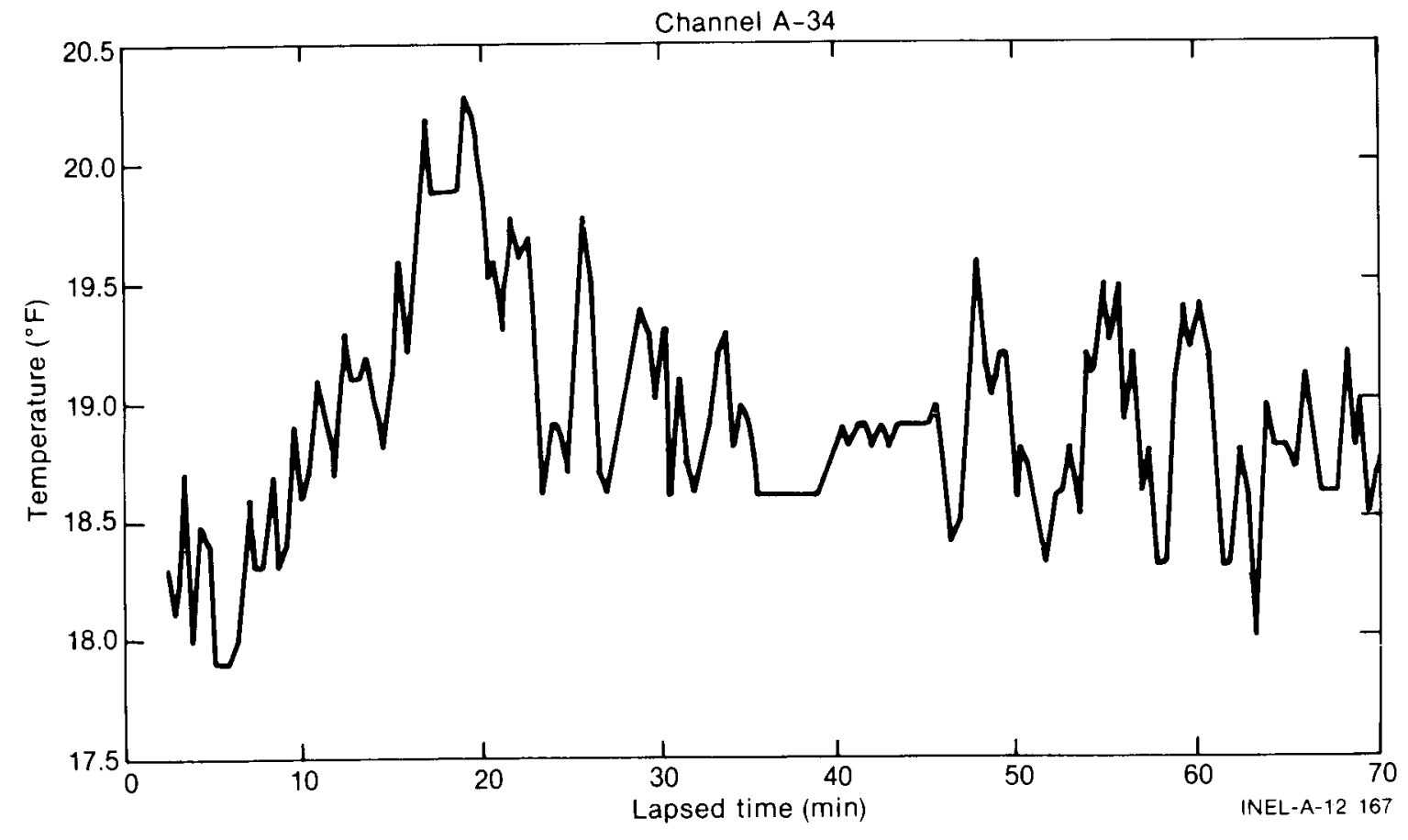

Fig. 63 Box C2/D2 flue. 


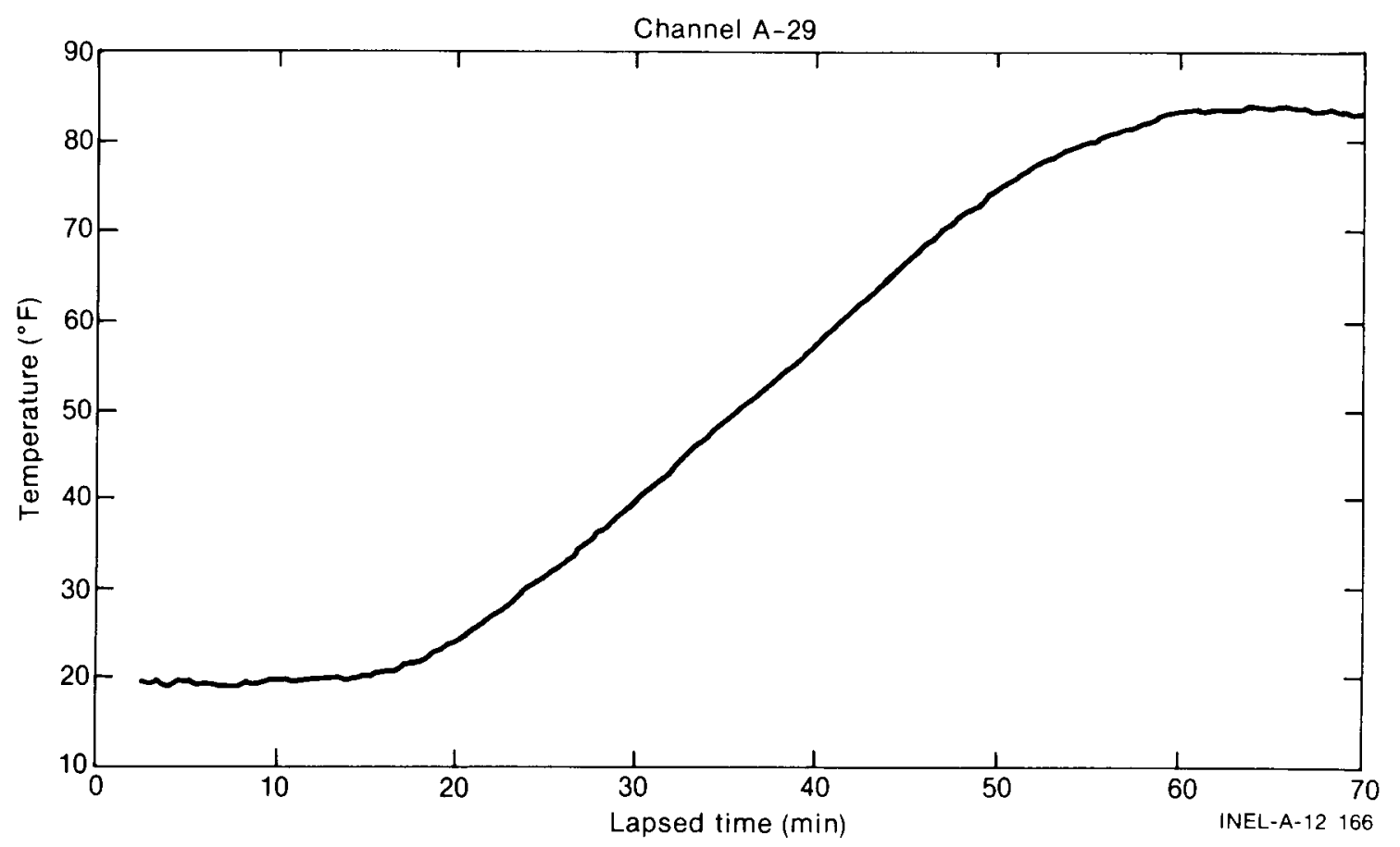

Fig. 64 Box C1 inside.

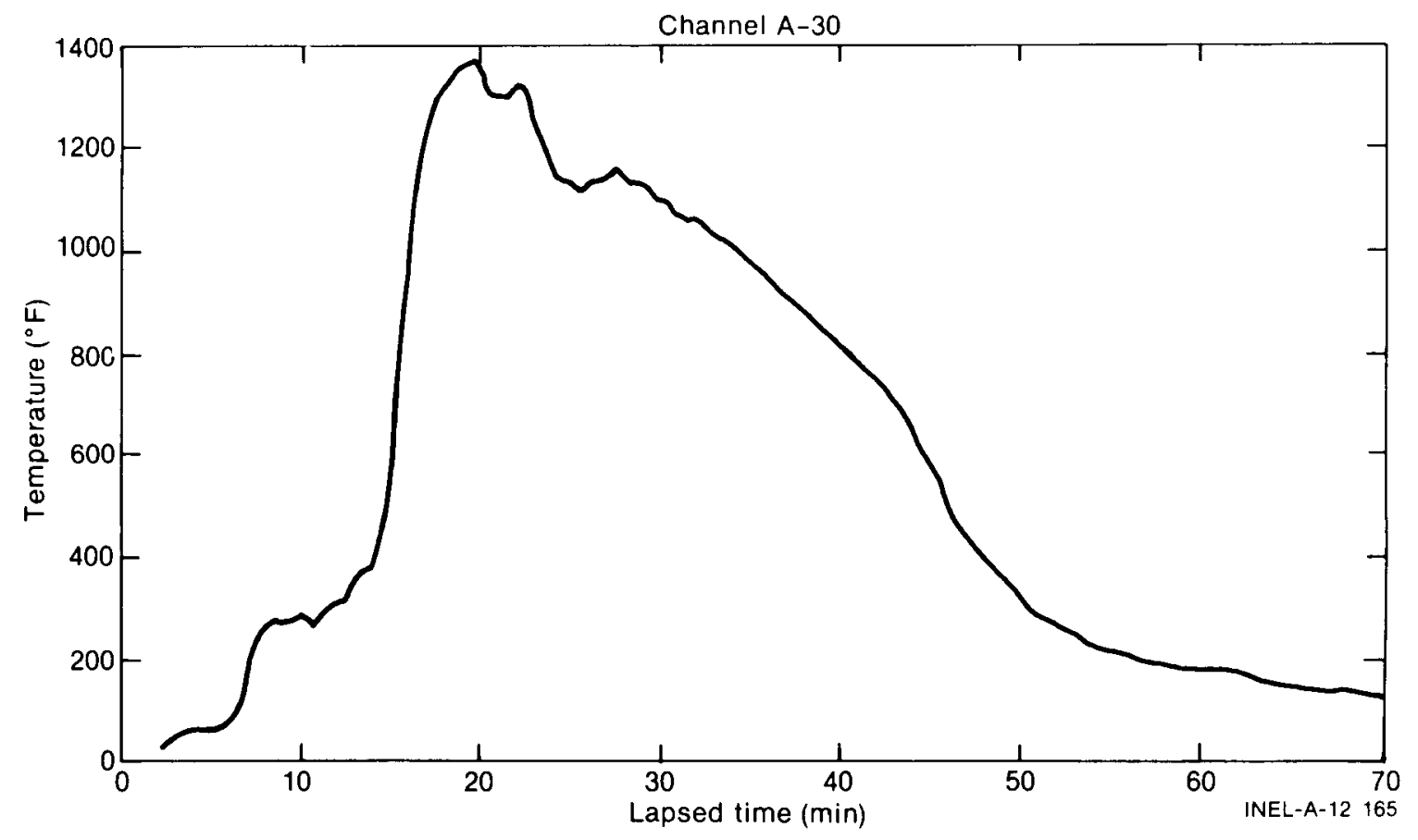

Fig. 65 Box $\mathrm{C} 1$ end face. 


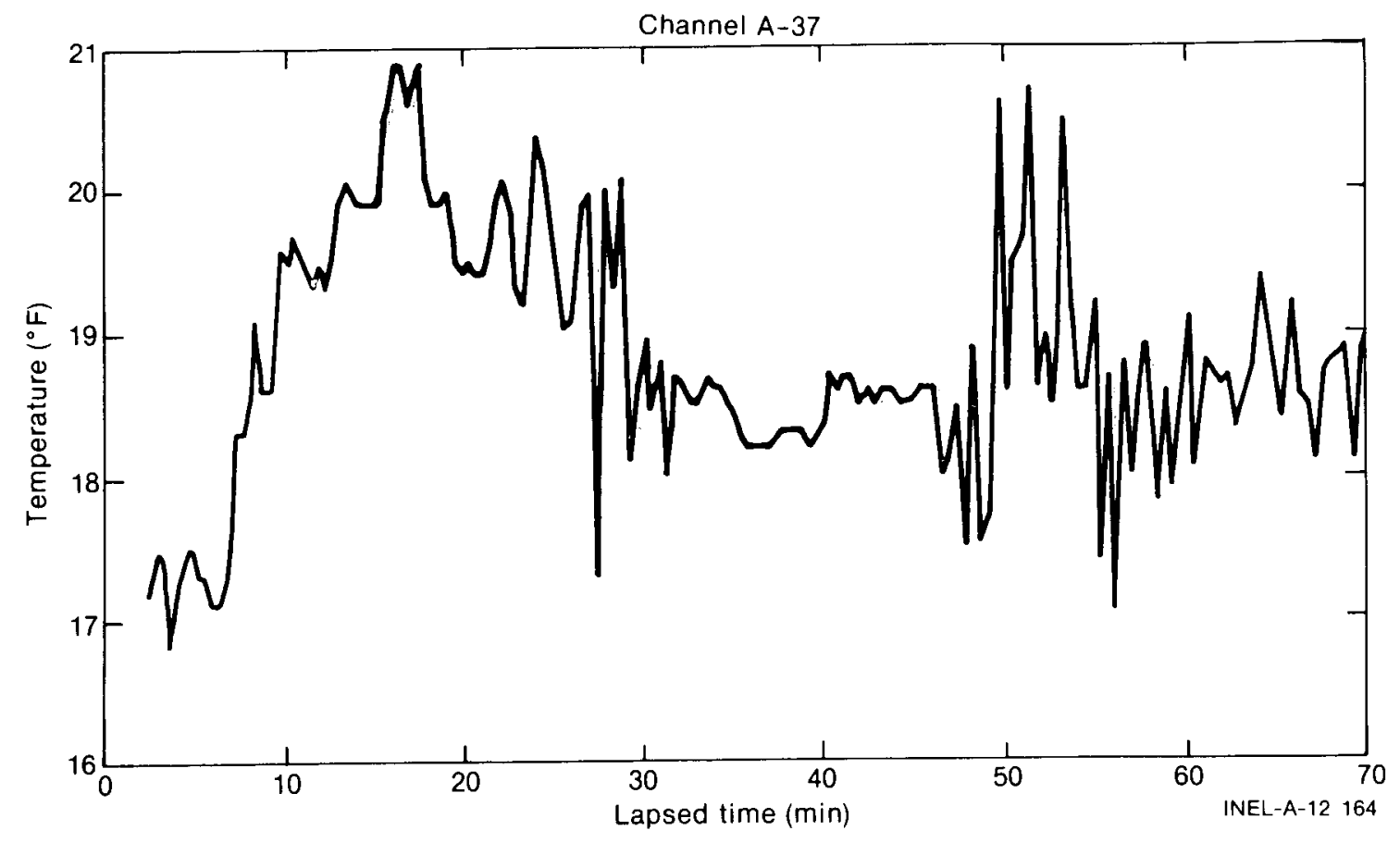

Fig. 66 Box C1/D1 flue.

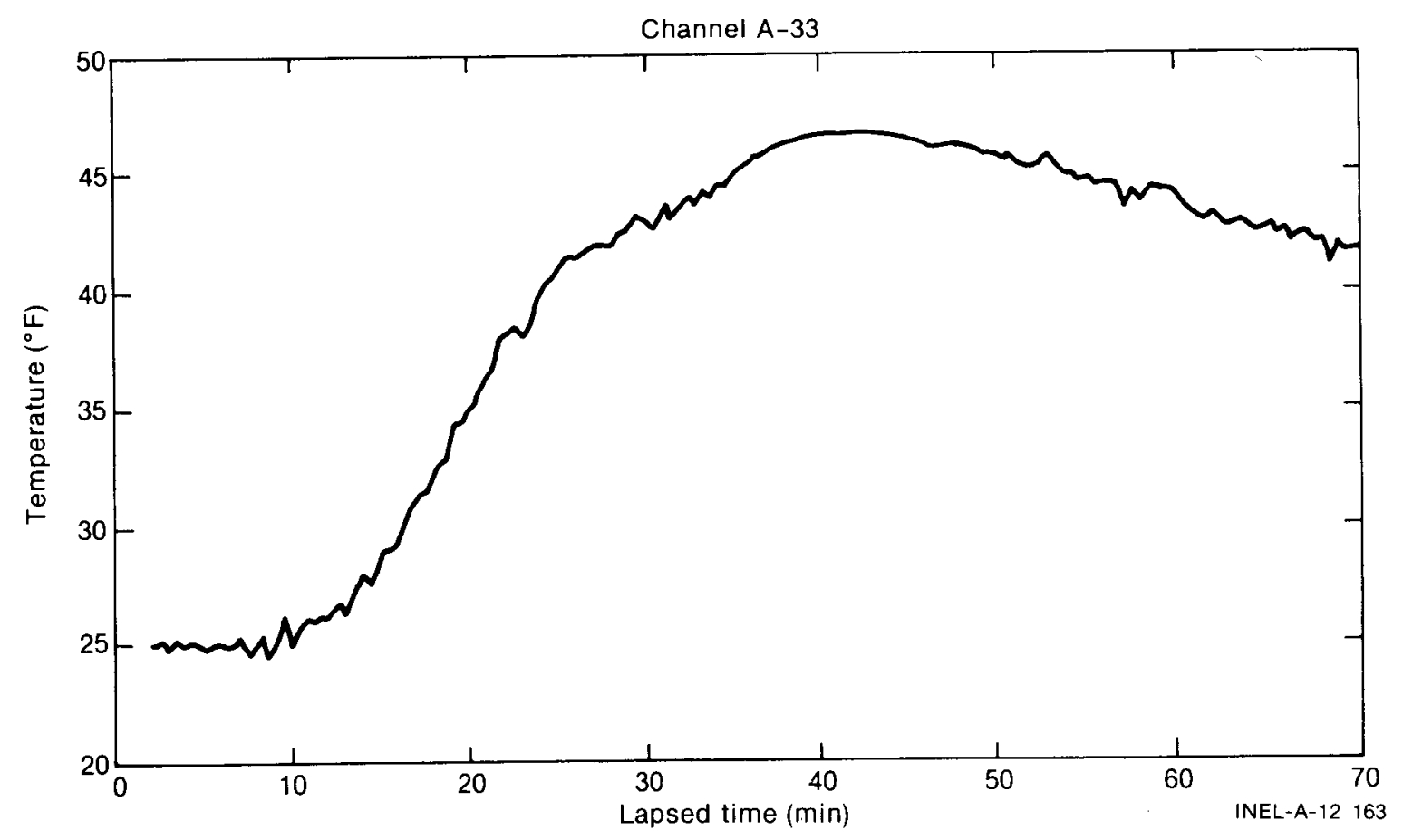

Fig. 67 Box D2 inside. 


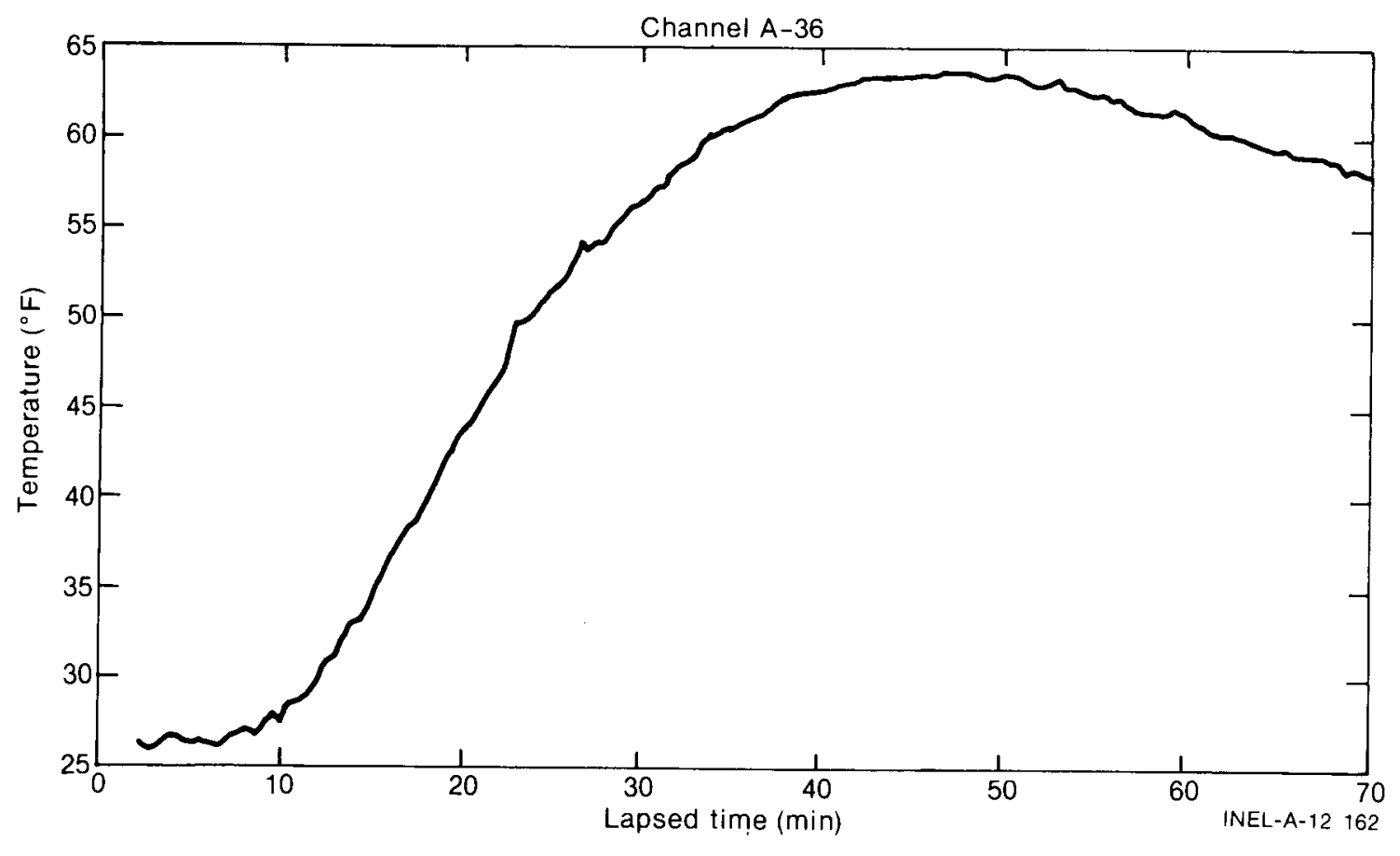

Fig. 68 Box D1 inside.

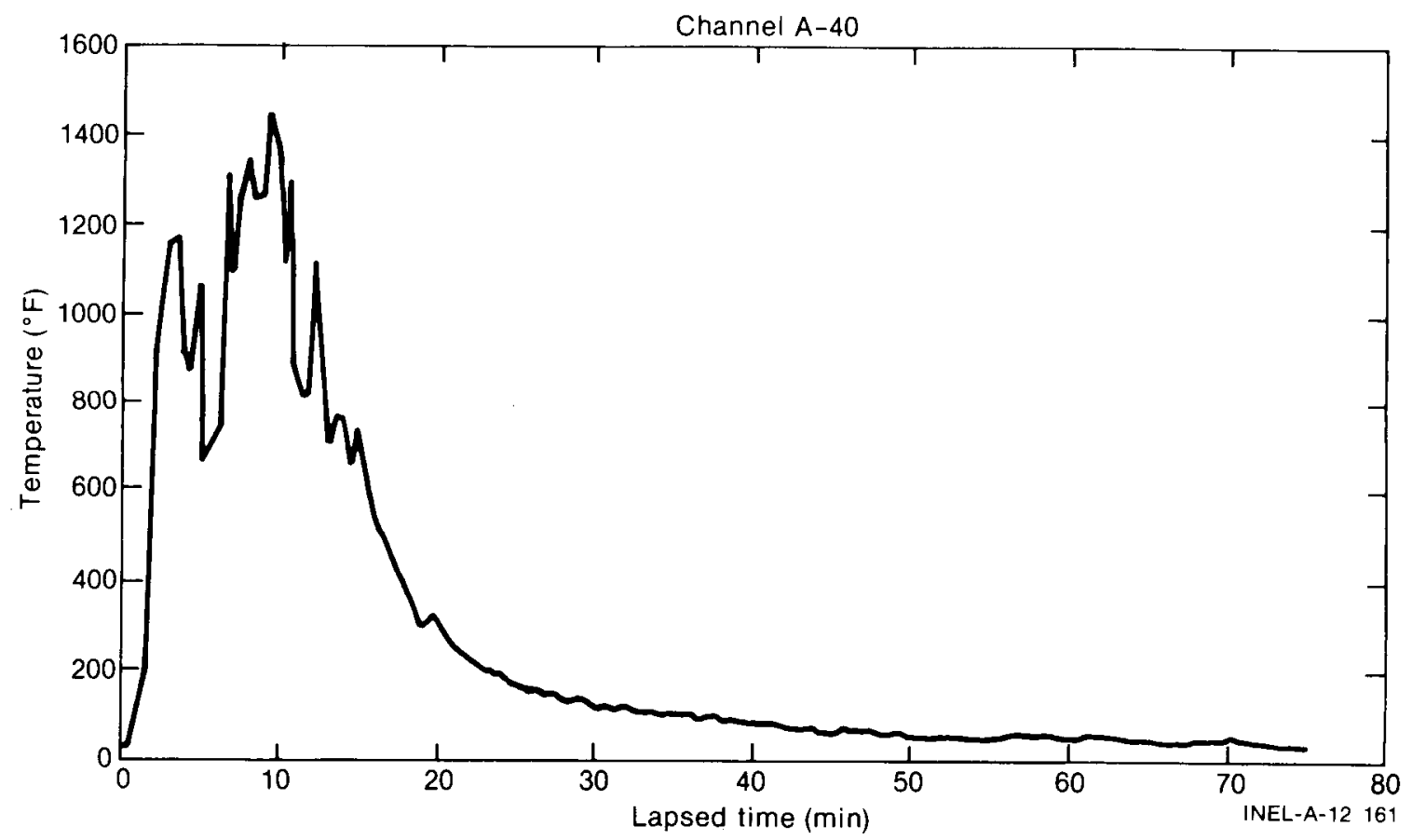

Fig. 69 TC TREE. 
Channel A-42

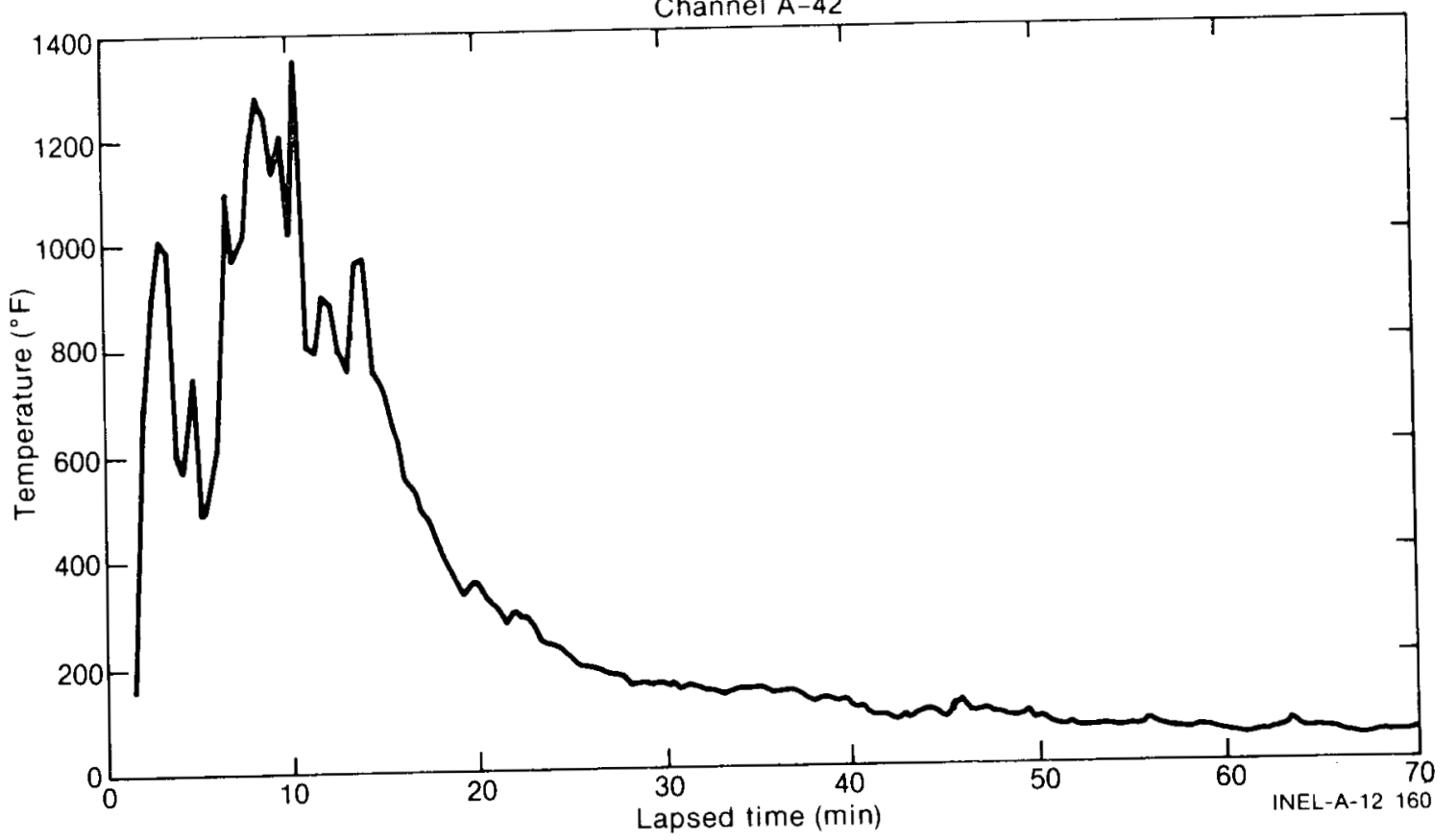

Fig. 70 TC TREE.

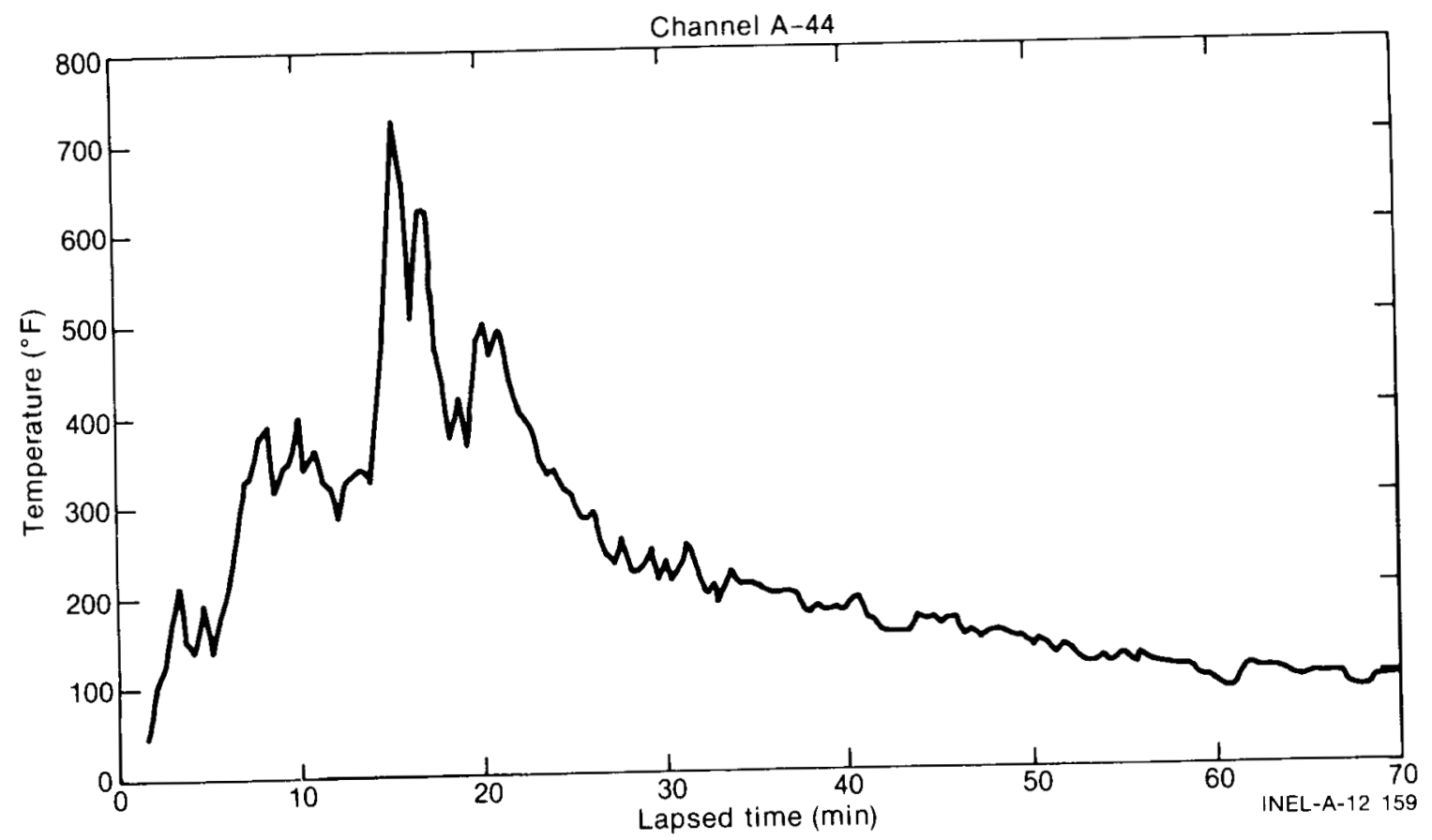

Fig. 71 TC TREE. 


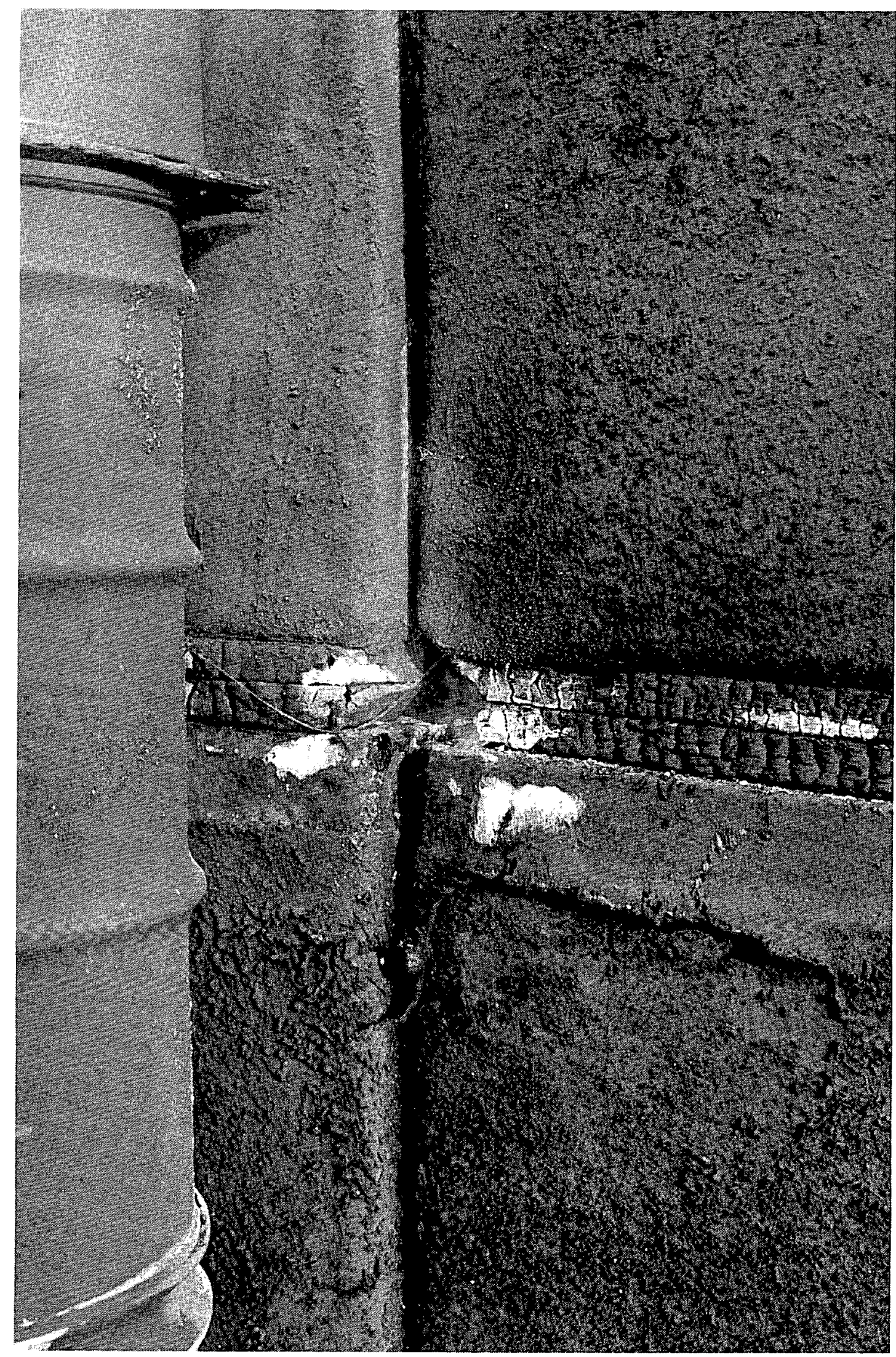

Fig. 72 Fire Test 2, after test view of boxes in rows 1 and 2, stacks 3 and 4. 


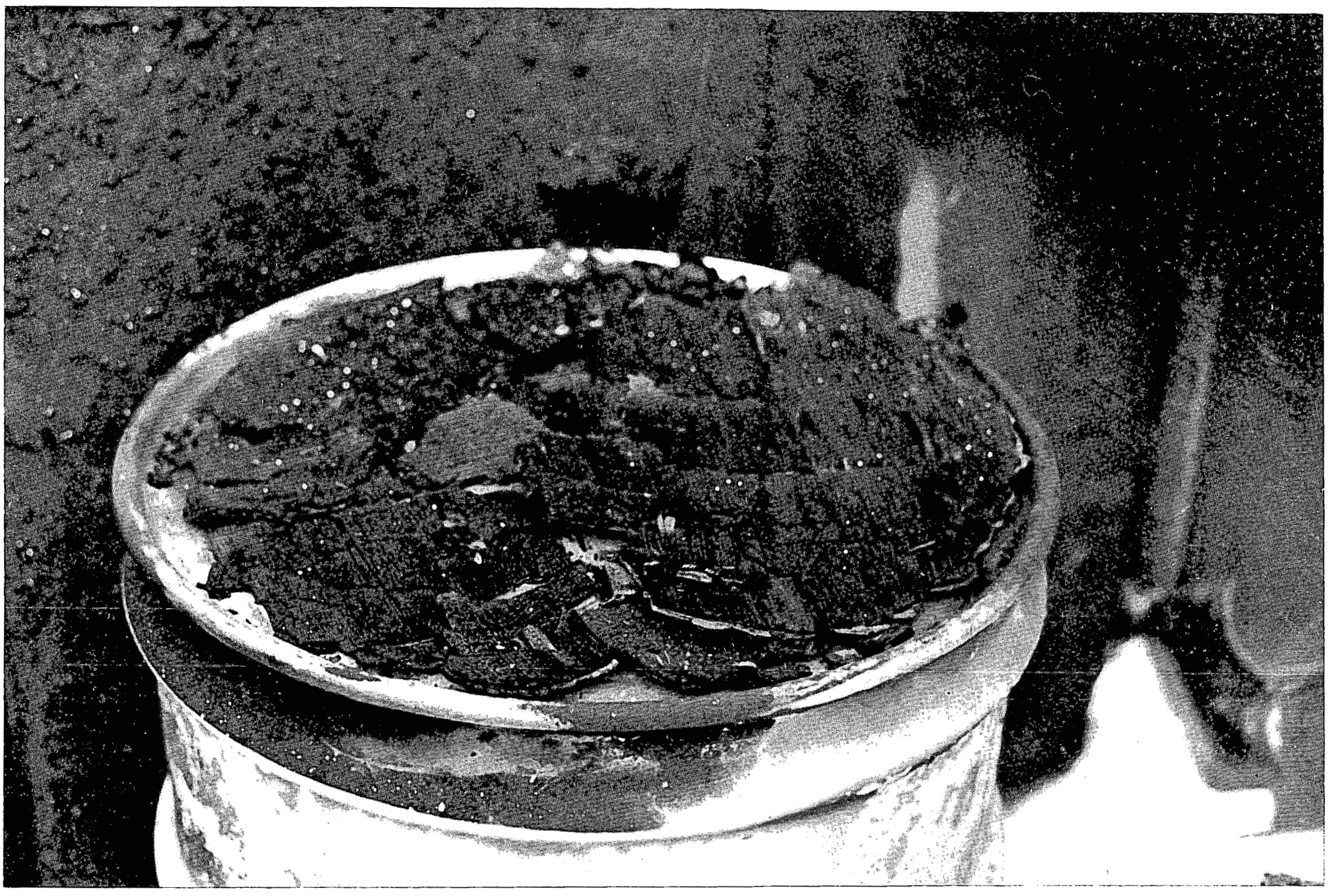

Fig. 73 Fire Test 2, remains of the fire retardant barrier between drum rows 1 and 2, facing box in row 1 , stack 3 . 


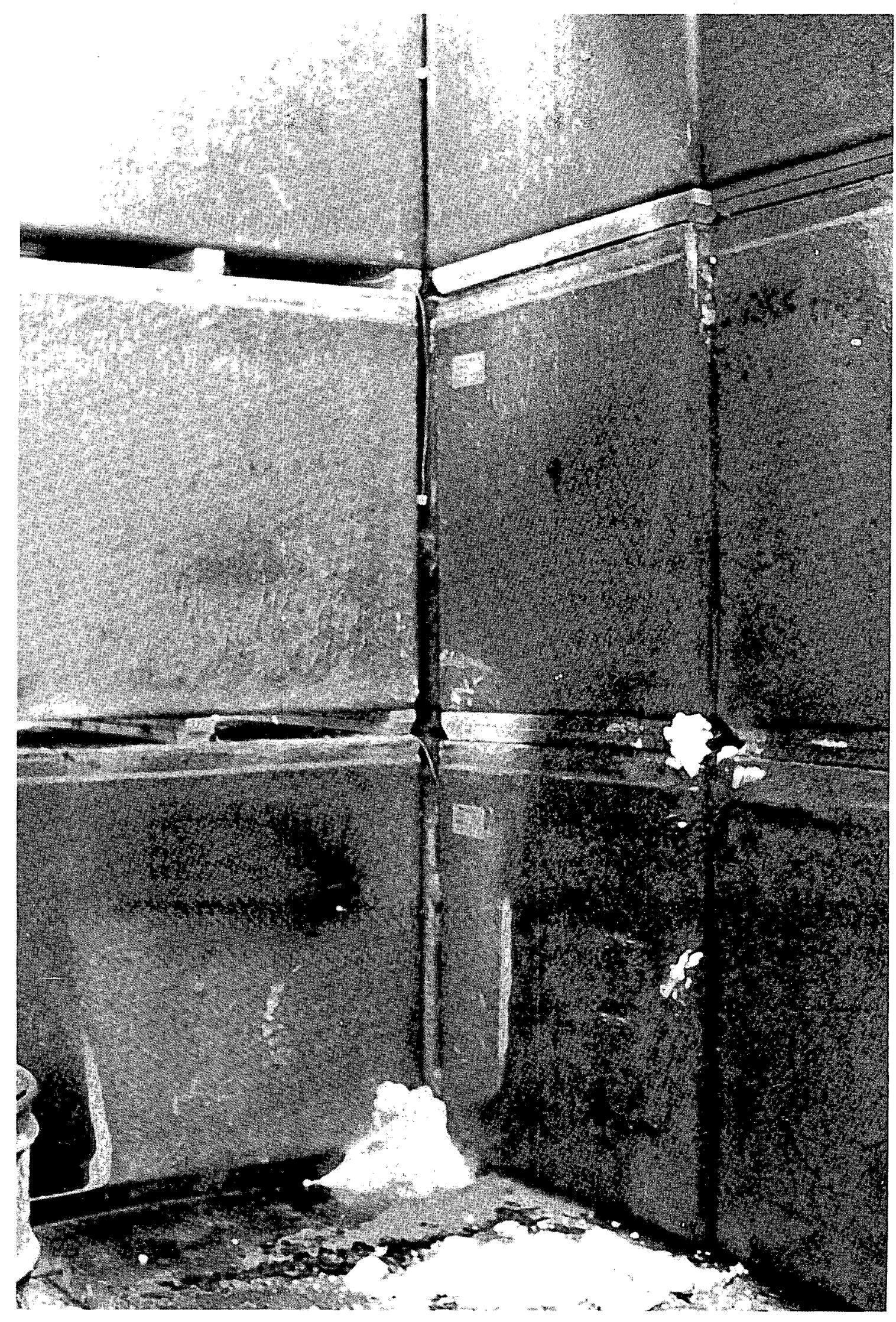

Fig. 74 Fire Test 2, after test view of inside corner after drums removal. 


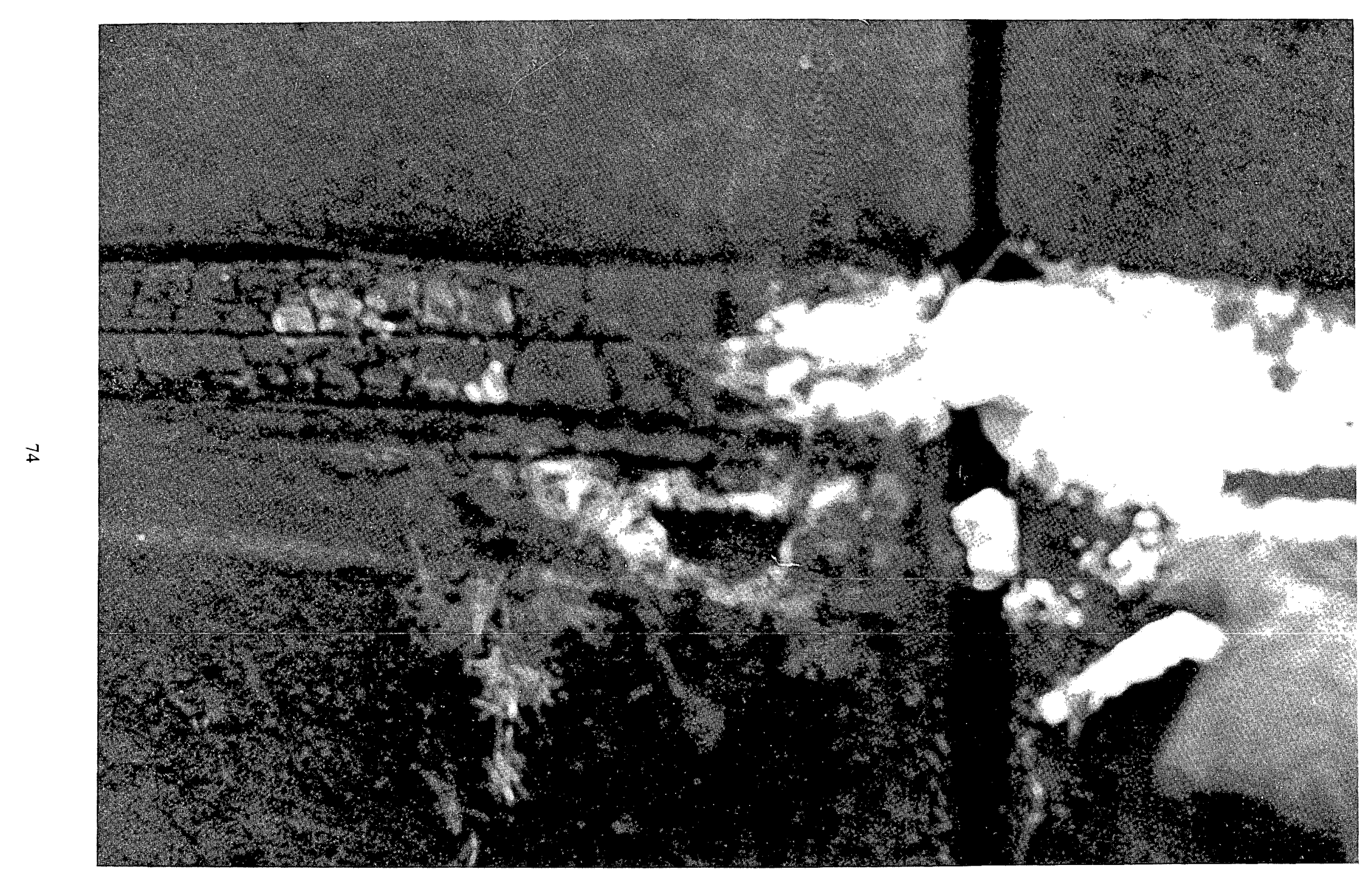

Fig. 75 Fire Test 2, penetration in upper end corner of box in row 1, stack 3. 


\section{ANALYSIS}

Two fire tests were successfully completed at the INEL on December 20 and 21,1978 . The waste container arrangements used for the tests were the image of the corner array used at the RWMC, which is considered to be the most critical from a fire standpoint. The fuel source was determined by considering the waste handling vehicles that would be operated at the face of the storage array. These two tests also postulated the events which are possible during routine operations at the RWMC, WIPP, and other storage facilities, but completely ignored sabotage situations.

The natural environmental conditions existing during the tests were considered but not analyzed for inclusion in this report. The natural environmental conditions were the same for both tests; that is, temperature $-5.6^{\circ} \mathrm{C}\left(22^{\circ} \mathrm{F}\right)$, average relative humidity of $87 \%$ and wind velocity and direction of approximately $8.05 \mathrm{~km} / \mathrm{hr}(5 \mathrm{mph})$ from the northeast. Although these environmental conditions were not analyzed and discussed in the report, some of the thermocouple data reveals the existence of the natural environmental condition. The energy lost by the fire in heating the cold waste containers to combustable temperatures, as well as the surrounding air, is axiomatic.

\section{IGNITION SOURCES}

The fuel source for the first test behaved much as expected. The ignition source for Fire Test 1 was 56.81 (15 gal) of \#2 diesel poured into a salt bed. The source was originally specified as 75.71 (20 gal), but when the ignition pan was filled with salt, 56.81 saturated the salt to overflowing the pan. The fuel was also poured in the flue spaces between steel drums to ensure a penetrating fuel distribution within the waste containers designed to produce a fire more severe than would be expected by an accidental spill outside the storage array. After ignition, the fire intensity quickly rose to a maximum of approximately $582^{\circ} \mathrm{C}$ $\left(1090^{\circ} \mathrm{F}\right)$ within the first $10 \mathrm{~min}$ into the test and then slowly diminished in intensity until just prior to terminating the test, the maximum intensity was approximately $218^{\circ} \mathrm{C}\left(425^{\circ} \mathrm{F}\right)$ at the termination of the test. Fire Test 1 was terminated when the DOT 7A FRP-coated boxes were considered to be in a state of sustained combustion, which was $40 \mathrm{~min}$ into the test. The rapid involvement and intensity of the fire source was due to the vaporization of the free standing fuel pooled above the salt pad. As the free standing fuel was consumed, the salt acted as a wick to the fuel and regulated the rate at which the vapors burned. Consequently, as the fuel was consumed, more salt was exposed and the vapor release slowed, and the intensity of the source fire continued to diminish. When the salt was removed from the source pan, the salt still contained a significant, but unmeasured, amount of \#2 diesel.

The source for Fire Test 2 was a free standing liquid pool type containing 15.11 (4 gal) of \#2 diesel. This source was calculated to be equivalent to a 75.7-1 (20-gal) fuel source uncontained spill (see Section I-1). The free standing liquid pool type source allows for quick vaporization of the fuel resulting in a quick, very intense fire. The source fire reached a maximum intensity of approximately $787^{\circ} \mathrm{C}\left(1450^{\circ} \mathrm{F}\right)$ within the first $10 \mathrm{~min}$ of the test, which was significantly hotter than the $582^{\circ} \mathrm{C}\left(1080^{\circ} \mathrm{F}\right)$ attained in the first test. The intensity of the source fire declined about as fast as it increased with the fuel source being consumed approximately $15 \mathrm{~min}$ into the test. Fire Test 2 was allowed to burn itself out, which it did about $75 \mathrm{~min}$ into the test. The DOT 7A FRP-coated boxes, when positioned in the test configuration and exposed to this source, never reached the state of sustained combustion.

\section{DOT 17C STEEL DRUMS}

DOT 17C steel drums with rigid PVC liners were used in both fire tests. Fire Test 1 used five steel drums positioned in the corner of the array in a single level. The steel drums were added to evaluate their overall effect on the fire. The steel drums were not instrumented nor were they physically sealed. Following ignition, the steel drums acted as a heat sink and slowed the flame spread to the face of the DOT 7A FRPcoated boxes. The drums resembled a flame surrounding barrier as the flames were contained within the drum flues. Although the drums were not sealed, the heat generated by the fire built up sufficient internal pressure to dislodge the drum lids, and in several cases, the pressure release was violent enough to dislodge 
the sealing ring from the lids. All drum lids were dislodged by 8 min into the test. After the lids were dislodged, flames eminating from inside the drums were visible, indicating that vaporization of the PVC liner was taking place. The rigid PVC liner exhibited highly flammable characteristics once the lids were dislodged. Besides the steel drums, the salt containing the source aided in slowing the velocity of the flame spread to the DOT 7A FRP-coated boxes. Flames first reached the boxes about $18 \mathrm{~min}$ into the test. Once the fire reached the face of the boxes, it was mainly contained within the flues between the drums and boxes. The external drum sides facing the DOT 7A FRP-coated boxes was opposite the areas on the boxes revealing the most fire damage: that is, where the drum face and box face was closest. The increased fire intensity in these regions is believed due to both the heat reflecting surface of the drums and the narrow gap between the box face and the drum. Prior to extinguishing the fire some $40 \mathrm{~min}$ into the test, flames were still coming from inside the drum. After the fire was extinguished and the drums tipped over, the part of the liner that was not consumed came out as residue or a thick black liquid.

Fire Test 2 also employed the DOT $17 \mathrm{C}$ steel drums, but following Fire Test 1, it was decided that the drums should be stacked four levels high. Therefore, Fire Test 2 used 16 DOT 17C steel drums positioned four per level and four drums high and each level was separated by a piece of 9.5 -mm (0.375-in.) fire retardant plywood.

For this test the drums were neither instrumented nor physically sealed. Following ignition, the drums acted as a heat sink and slowed the flame spread to the DOT 7A FRP-coated boxes. The flames spread significantly faster in this test, reaching the boxes in approximately 2 min, than in Fire Test 1 . This faster flame spread was believed to be the result of the fire retardant plywood barrier and the lack of salt in the source. The fire retardant plywood barrier between the barrel levels disrupted the flue effect and contained the fire and its associated energy within the flue spaces of the first level of drums, thus aiding the vaporization of the source and increasing the flame spread velocity. As the bottom fire retardant plywood barrier was consumed, the flames involved the second level of drums in the fire. However, the flue effect continued to be disrupted by the flame retardant barrier separating the drums in level 2 from those in level 3 . The second barrier drafted the flames upward and outward from the drums. As was the case in the first test, the drums built up internal pressure rapidly. However, unlike the first test, the additional drum lid sealing force applied by the weight of the stacked drums provided for a higher internal drum pressure, which resulted in increasing the violence of the pressure releases. When the internal drum pressure was sufficient to dislodge the drum lid, the vaporized rigid PVC liner commenced to burn. The rigid PVC liners again exhibited their combustible characteristics as long as the heat was sufficient for vaporization. The external drum sides facing the DOT 7A FRP-coated boxes was opposite the areas on the box faces revealing the most fire damage. The fire retardant plywood barriers, by directing the flames upward and outward, directed the flames against the box faces and up through the slight gap between the box face and barrier edge. Until the barrier was consumed, the intensity of the fire was mainly confined to the area below the barrier.

\section{DOT 7A FRP-COATED BOXES}

Dot 7A FRP-coated boxes, stacked in a simulated RWMC corner array, were used in both fire tests. The DOT 7A boxes are constructed of $1.9-\mathrm{cm}(0.75 \mathrm{in}$.) thick plywood covering a $5.08-\times 10.16-\mathrm{cm}$ $(2-\times 4$-in.) stud frame $1.22 \times 1.22 \times 2.13 \mathrm{~m}(4 \times 4 \times 7 \mathrm{ft})$. The plywood box exterior is coated with a minimum of $0.318 \mathrm{~cm}(0.125 \mathrm{in}$.) of FRP (roving strand fiber reinforced polyester) sprayed on as part of a mixture of methyl ethyl keytone peroxide and Co-rezyn 1664. Co-rezyn 1664 contains styrene and/or vinyl toluene and/or acrylate monomers.

During Fire Test 1, the flames reached the DOT 7A boxes approximately $18 \mathrm{~min}$ into the test and after the boxes were believed to be in a state of sustained combustion, which was $40 \mathrm{~min}$ into the test, the fire was extinguished. Therefore, the boxes were directly exposed to, and involved in, the fire for approximately $22 \mathrm{~min}$. The maximum temperature recorded was $746^{\circ} \mathrm{C}\left(1376^{\circ} \mathrm{F}\right)$ on the face of the box A1 (row 1, stack 1), and $691^{\circ} \mathrm{C}\left(1277^{\circ} \mathrm{F}\right)$ on the face of the box $\mathrm{C} 1$ (row 1, stack 3). The maximum inside temperature of the same two boxes was $20^{\circ} \mathrm{C}\left(68^{\circ} \mathrm{F}\right)$ and $16^{\circ} \mathrm{C}\left(61^{\circ} \mathrm{F}\right)$, respectively. This attests to the insulating ability of the plywood. The box facings in the second row of boxes recorded significantly lower temperatures. That is, temperature reduction by a factor of at least 2 . However, the temperature inside the boxes in the 
second row showed a slight increase due to the rising heat from the fire. The maximum temperature recorded in any one of the box flue spaces was $49^{\circ} \mathrm{C}\left(121^{\circ} \mathrm{F}\right)$, which was recorded in the flue between stacks 1 and 2 at the top of row 1 . The remaining box flue temperatures were lower by a factor greater than 1.5. This low flue temperature was surprising, but it is believed to be due to the cold air being both blown and drafted through the flue spaces to feed the fire. Had the breeze been coming from another direction, the flue spaces would undoubtedly witnessed higher temperatures. In general, the temperatures of both the box surface and interior continued to raise as the test progressed with the maximum temperatures being recorded just prior to extinguishing the fire. The fire was completely extinguished using an estimated $94.6 \mathrm{I}$ $(25 \mathrm{gal})$ of water.

After the fire had been estinguished, the damage assessment revealed that the FRP-coating on the face of the box A1 (row 1, stack 1) had been consumed and the plywood had experienced combustion as indicated by the charred alligator surface. No boxes were breached or destroyed during Fire Test 1 . The uncoated skids attached to the bottom of the boxes revealed heavy char and heavy fire damage, which verified the visual observation that the skids readily ignited when exposed to a fire of the intensity witnessed in the test.

In Fire Test 2, the flames reached the DOT 7A FRP-coated boxes at approximately 2 min into the test and the boxes self-extinguished about $70 \mathrm{~min}$ into the test, at which time the test was terminated. Therefore, the boxes were directly exposed to and involved in the fire for about $73 \mathrm{~min}$. The maximum temperature recorded was $745^{\circ} \mathrm{C}\left(1374^{\circ} \mathrm{F}\right)$ at the face of the box $\mathrm{Cl}$ located in row 1 , stack 3 . The next highest temperature recorded was $115^{\circ} \mathrm{C}\left(239^{\circ} \mathrm{F}\right)$ at the face of the box in row 2 , stack 3 (C2). The temperature recorded inside these boxes was $29^{\circ} \mathrm{C}\left(84^{\circ} \mathrm{F}\right)$ and $2^{\circ} \mathrm{C}\left(35^{\circ} \mathrm{F}\right)$, respectively. The face of the Box $\mathrm{C} 3$ located in row 3 , stack 3 recorded a maximum temperature of $49^{\circ} \mathrm{C}\left(120^{\circ} \mathrm{F}\right)$ and an internal temperature of $-3^{\circ} \mathrm{C}\left(26^{\circ} \mathrm{F}\right)$. The temperature recorded inside the boxes $\mathrm{D} 1$ and $\mathrm{D} 2$ located in rows 1 and 2, stack 4 were $17^{\circ} \mathrm{C}\left(63^{\circ} \mathrm{F}\right)$ and $8^{\circ} \mathrm{C}\left(46.7^{\circ} \mathrm{F}\right)$. The box Al located in row 1 , stack 1 recorded $63^{\circ} \mathrm{C}$ $\left(145.3^{\circ} \mathrm{F}\right)$ on the face, whereas the inside temperature recorded was $6^{\circ} \mathrm{C}\left(42.9^{\circ} \mathrm{F}\right)$. All other box and flue temperature recordings were less than $24^{\circ} \mathrm{C}\left(75^{\circ} \mathrm{F}\right)$. Two reasons are believed responsible for the above temperature profile: first, the fire retardant plywood barriers between the drum levels helped contain the fire to the lower level of boxes, and second, the source fire was an intense fire of short duration and lacked the energy required to propagate the fire through sustained combustion. The reason for the cool flue temperatures is believed to be the same as in the first test. The temperatures above verify the visual observation that the fire activity mainly involved the boxes located in stack 3 , which was believed due to the location of the box and drum flue spacing. After the fire had self-extinguished, a visual damage assessment was conducted. The skids on the bottom of the boxes in row 2, stacks 3 and 4 , showed heavy fire damage. The faces of the box were blackened and, although burned fiberglass remained intact on the face of the boxes, some wood burning had taken place under the fiberglass. When the burned fiberglass matting was removed to ensure all the fire was out, a small breach was discovered in the top right hand corner of the

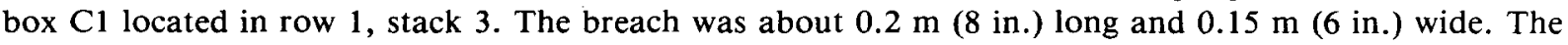
location of the breach indicates that the top $0.08 \mathrm{~m}(3 \mathrm{in}$.) of the box, which is the area sealed over with FRP coating after the box is loaded, is more susceptible to fire damage than is the rest of the FRP-coated box. This weakness in the FRP-coated top seal was also noticed in Fire Test 1. 


\section{CONCLUSIONS AND RECOMMENDATIONS}

The following conclusions are derived from the results presented in this report:

(1) No. 2 diesel spilled on a salt floor and ignited will propogate slower, and after a quick intense fire, the intensity of the fire will continue to decrease as more salt is exposed, creating a wick effect. Salt acts to control the vaporization rate of the fuel resulting in a prolonged fire of decreasing intensity. The salt and fuel mixture used in this test will produce and maintain enough heat energy to place the DOT 7A FRP boxes in the test configuration in a state of sustained combustion.

(2) The resulting fire intensity from a freestanding pool type fire of the tested magnitude is both severe and short in duration. Although the fire intensity resulting from the source in Fire Test 2 was severe, its duration did not permit enough heat energy to be imparted to the DOT 7A FRP boxes in the test configuration to bring them into a state of sustained combustion.

(3) The DOT 17C steel drums acted as a heat sink and retarded the flame spread to the boxes, but once the fire reached the boxes, the flue spaces and heat reflecting surfaces of drums contributed to the fire by radiating heat and drafted the fire against the boxes. The drums exhibited a tendency for a rapid internal pressure rise and, if the drums would have been physically sealed to permit the pressure to continue to build, a potentially hazardous situation could result, which must be considered when attempting to extinguish a severe fire containing DOT $17 \mathrm{C}$ steel drums. The time required for the fire to reach the boxes, as well as the energy used in propagating through the drums, are important factors when considering the fire fighting response time. The rigid PVC liner contained inside each drum is highly combustible when the drum lid is dislodged, and vaporization of the liner is a contributer to the fire intensity. The fire retardant plywood barriers between the drum levels does retard the fire by disturbing the flue effect and confining the fire to the bottom of the stack.

(4) The lapse time required for a fire of these magnitudes to penetrate a DOT 7A FRP box was shown to be in excess of $40 \mathrm{~min}$. The fire was also shown to be easily extinguished using a small amount of water [estimated to be 94.61 ( $25 \mathrm{gal})]$. The two parts of the DOT 7A FRP boxes that proved most susceptable to the fire, and revealed the most fire damage are the box skids and the top sealing surface, which are adjacent to the air space created by the skids. The present RWMC stacking configuration of the DOT 7A FRP boxes provide air spaces allowing oxygen to reach the fire.

The DOT 7A FRP box is an acceptable radioactive waste storage container provided the amount of fuel used in the vehicles is less than $75 \mathrm{l}(20 \mathrm{gal})$ and the storage facility where these boxes are stored is equipped with an operating early warning fire detection system or a fire suppression system. The fire detection or suppression systems are required only at facilities where the boxes are stacked in an open storage environment (above ground, open pit, etc.). If the boxes are stored in a closed environment (buried, encased, etc. where the oxygen atmosphere is insufficient for ignition), niether the fire detection nor the fire suppression systems are required.

The following recommendations are made from the preceeding conclusions.

(1) Ignition source:

a. Vehicles operating within $1.8 \mathrm{~m}(6 \mathrm{ft})$ of a storage array stacked on a flat salt floor (WIPP environment) should be limited to a fuel capacity of less than 56.81 (15 gal) of \#2 diesel 
b. Vehicles operating within $1.8 \mathrm{~m}(6 \mathrm{ft})$ of a storage array stacked on a flat hard surface (RWMC environment) should be limited to a fuel capacity of 75.71 ( 20 gal) of \#2 diesel.

(2) DOT $17 \mathrm{C}$ steel drums and rigid liners:

a. Materials exhibiting noncombustible characteristics should be investigated for inclusion into therigid drum liner fabrication

b. A pressure relief mechanism for the drum should be investigated for inclusion to the drums

c. Fire retardant barriers should be used between drum levels, and different fire retardant barrier materials should be investigated for use in drum stacking.

(3) DOT 7A FRP boxes:

a. The combustible characteristics of the FRP coating should be investigated to ascertain if fire retardant chemicals can be included, or if less combustible fiberglassing materials are available

b. Enforcement of EG\&G Specification ES 50376 (WMP-572013), or equivalent, for coating external box surfaces, including the skids, is required

c. Noncombustible container designs should be investigated for cost/benefit comparison to the DOT 7A FRP box

d. Methods should be investigated for reducing or eliminating the air gaps created by the box skids and box stacking arrangements to reduce the amount of oxygen available to feed the fire

e. Methods should be investigated for improving the box top sealing techniques.

(4) An early warning fire detection system or fire suppression system should be in operation at the storage facility where DOT 7A FRP boxes are used as storage containers. 


\section{REFERENCES}

1. John D. Jensen, Fire Test on DOT 7 A Boxes, TREE-1356 (June 1979).

2. M. L. Kramn, "Combustibility Test Program and Impaction Waste Acceptance Criteria', letter, Sandia Laboratories, (November 1, 1978). 
Internal Distribution

$$
\begin{aligned}
& 1 \text { - Chicago Patent Group - DOE } \\
& 9800 \text { South Cass } \\
& \text { Argonne, IL } 60439 \\
& 1 \text { - R. L. Blackledge } \\
& \text { Idaho Operations 0ffice - DOE } \\
& \text { Idaho Fal1s, ID } 83401 \\
& \text { 1- H. P. Pearson } \\
& \text { Information Processing - EG\&G } \\
& 6 \text { - INEL Technica 1 Library } \\
& 20 \text { - Author } \\
& 8 \text { - Special Internal }
\end{aligned}
$$

\section{External Distribution}

$$
\begin{aligned}
& \text { 3 - Special External } \\
& \text { 27 - Technical Information Center } \\
& \text { Total Copies Printed: } 67
\end{aligned}
$$

